\title{
AN ANALYSIS OF IMPORT-EXPORT PROCEDURES AND PROCESSES IN CHINA
}

\author{
By
}

Bala Ramasamy*

\begin{abstract}
* Professor, China Europe International Business School (CEIBS), Shanghai, China. This work was carried out with the aid of a grant from IDRC, Canada and is part of an ARTNeT Trade Facilitation Study on Improving Regional Trade Procedures and Process (see www.artnetontrade.org for details). The technical support of the United Nations Economic and Social Commission for Asia and the Pacific is gratefully acknowledged. The opinion figures and estimates are the responsibility of the author and should not be considered as reflecting the views or carrying the approval of the United Nations, ARTNeT and the CEIBS. This paper benefited from comments received from participants during the ARTNeT Trade Facilitation Research Team Meeting on Improving Regional Trade Procedures and Process and Asia-Pacific Trade Facilitation Forum, 4-6 October 2010, Kuala Lumpur, Malaysia. Any errors are the responsibility of the author, who can be contacted at bramasamy@ceibs.edu
\end{abstract}

The Asia-Pacific Research and Training Network on Trade (ARTNeT) is aimed at building regional trade policy and facilitation research capacity in developing countries. The ARTNeT Working Paper Series disseminates the findings of work in progress to encourage the exchange of ideas about trade issues. An objective of the series is to get the findings out quickly, even if the presentations are less than fully polished. ARTNeT working papers are available online at www.artnetontrade.org. All material in the working papers may be freely quoted or reprinted, but acknowledgment is requested, together with a copy of the publication containing the quotation or reprint. The use of the working papers for any commercial purpose, including resale, is prohibited. 


\section{Table of Contents}

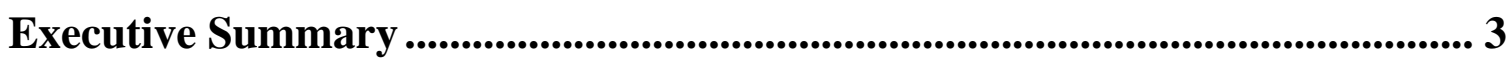

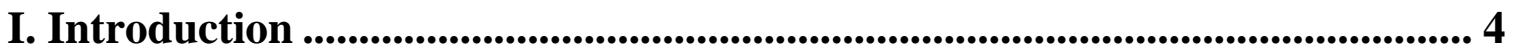

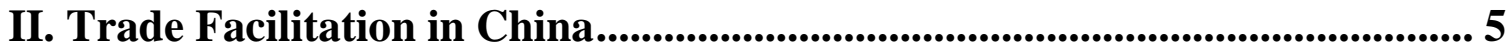

III. Trade Facilitation in China - A Business Process Analysis (BPA) .......... 11

Export Process Analysis for Selected Products ................................................. 14

Export of Garments to Japan ................................................................... 14

Export of Electronic Products to Thailand ...................................................... 18

Import Process Analysis for Selected Products................................................... 19

Import of Fabric/ Accessories and Automobile Components from Japan

IV. Observation and Discussion....................................................................... 27

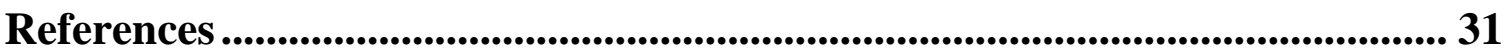

Appendices: BPA Charts.......................................................................................... 34 


\section{Executive Summary}

Recent research by various international organizations including the World Bank, OECD, ADB and UNCTAD suggest that customs and administrative procedures have substantial effects on trade flows between countries. These procedures and practices can act as significant barriers to international trade and it is not surprising that these have become the focus of attention, now that tariff and other quantitative barriers have and continue to be reduced. Since becoming a full fledge member of the WTO, China has made significant progress in the trade liberalization process. Recognizing trade facilitation as an important effort to spur further trade, China has made significant improvements in the procedures behind-the-border. The World Bank Doing Business 2010 rank China at number 47 in Trading Across Borders. It takes between 21 and 24 days to export/import involving 6-7 documents at a cost of USD500-545. While days to trade and number of documents are close to the East Asia average, the cost in China is about 55\% of the average East Asia mark.

Previous research on trade facilitation in China has taken a macro and/or a survey based approach. The objective of this study is to drop one level lower to evaluate in detail the processes involved in the export and import of goods. We use the Business Process Analysis (BPA) methodology such that we are able to trace all the steps and procedures involved in the process and consider the time and cost involved in each one of these steps. We identified 4 products and two countries for the in-depth analysis. To map export procedures, the project focused on garment and electronic exports to Japan and Thailand, while for imports, textiles and automobile parts from Japan has been the focus of analysis.

Our findings are somewhat different from those of the World Bank. The number of days for the export and import processes is markedly lower than the WB study. Our respondents claim that the process takes between 9 to 14 days. However, the number of documents involved in the process is much higher than the WB study, as many as 17 compared to only 7 reported in the WB study. We also found the costs to be marginally lower than claimed by the WB. We attribute this partly to the nature of our respondents who have long term relationships with the buyers/sellers, as well because of the use of freight forwarders and customs brokers who are very familiar with the various processes and customs officials. Compared to effect of electronic documents, the role of customs brokers in facilitating trade seems more effective in China. Using more Information Technology in trade facilitation will only be effective when the approval system is automatic rather than on a case-by-case basis. 


\section{Introduction}

In the $4^{\text {th }}$ Quarter of 2009, the Chinese economy grew at an enviable pace of $10.7 \%$ and clocked an annual growth rate of $8.7 \%$ for the whole of 2009. In sharp contrast, the World Bank has predicted that the Japanese economy would shrink by $5.4 \%$ in the same year, thus putting China on a comfortable path towards becoming the second largest economy in the world in the very near term. International trade - which had been an engine of growth of the Chinese economy since the beginning of the economic reforms in 1979 - was significantly slower in 2009 (exports and imports decreased 16\% and $11.2 \%$, respectively $)^{1}$ - but by November 2009 , growth was already at hand. In December 2009, trade increased more than 30\%. This comes as no surprise as China's trade historically has grown faster than output. See Figure 1.

Figure 1: China: Growth in Output and Trade

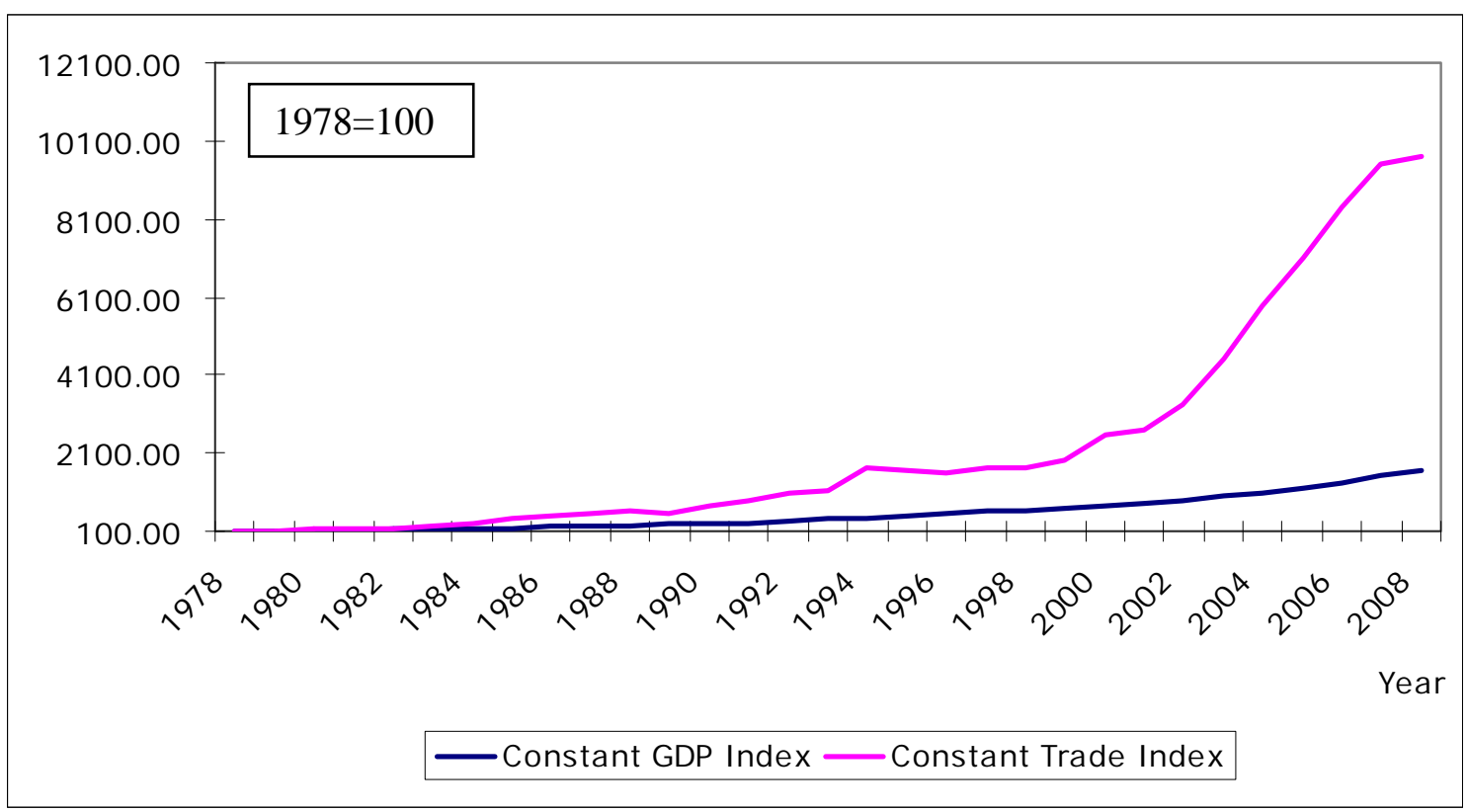

Source: China Statistical Yearbook, various years

Despite a focus on the domestic economy by choice and under pressure from developed economies, international trade will continue to be an important driver of the Chinese economy. The removal of trade restrictions in the 1980s and further liberalization of the trade sector in the 1990's culminated with the WTO membership in 2001. A quick look at the rate at which China has decreased its tariff barrier (Table 1) is a sign of China's commitment to its policy of openness. From as high as $42.9 \%$ in the 1980s and early 1990s, it is now less than $10 \%$. This is lower than any other large developing economy (BRIC). In terms of non-tariff barriers (NTBs), significant efforts

\footnotetext{
${ }^{1}$ National Bureau of Statistics, http://www.stats.gov.cn/english/newsandcomingevents/t20100121_402615502.htm
} 
were made to liberalize trading rights and removing quotas, licenses, specific tendering arrangements and price controls, such that its border barriers were reduced to Southeast Asian levels. $^{2}$

No observer can deny the speed and depth of the trade liberalization process that China has been engaged in over the last 40 years. Nevertheless, opportunities for further improvements remain. As the volume and number of players in the trading scene increase, so will the complexity of transactions. To ensure the trade engine is functioning smoothly, trade facilitation, with its “... focus on rationalizing procedures ... (and) ... a need for policy makers to look beyond at-the-border trade procedures and into regulations affecting existing and potential importers and exporters within the broader domestic business environment” ${ }^{3}$ becomes imperative.

Table 1. China: Simple Applied Average Tariffs (\%)

\begin{tabular}{|c|c|c|c|}
\hline & All products & Agricultural & Industrial \\
\hline $\mathbf{1 9 9 2}$ & & & 44.9 \\
\hline $\mathbf{1 9 9 3}$ & 42.9 & 36.2 & 41.8 \\
\hline $\mathbf{1 9 9 4}$ & 39.9 & 33.3 & 37.6 \\
\hline $\mathbf{1 9 9 6}$ & 36.3 & 32.1 & 23.1 \\
\hline $\mathbf{1 9 9 7}$ & 23.6 & 25.4 & 17.5 \\
\hline $\mathbf{1 9 9 8}$ & 17.6 & 17.9 & 17.4 \\
\hline $\mathbf{2 0 0 1}$ & 17.5 & 17.9 & 14.3 \\
\hline $\mathbf{2 0 0 3}$ & 15.6 & 23.2 & 11.1 \\
\hline $\mathbf{2 0 0 4}$ & 12.2 & 17.9 & 10.1 \\
\hline $\mathbf{2 0 0 5}$ & 11.1 & 16.3 & 9.3 \\
\hline $\mathbf{2 0 0 7}$ & 10.2 & 15 & 8.9 \\
\hline
\end{tabular}

Source: lanchovichina and Martin, 2001;Trade Policy Review,2006,2008

\section{Trade Facilitation in China}

Trade facilitation is defined by the WTO as "the simplification and harmonization of international trade procedures" covering the "activities, practices and formalities involved in collecting, presenting, communicating and processing data required for the movement of goods in international trade". ${ }^{4}$ In an age of international production

${ }^{2}$ Erixon, et. al. 2008

${ }^{3}$ Duvall and Utoktham (2009), p.2.

${ }^{4}$ OECD (2005), p. 2 
networks and the globalization of markets, the behind-the-border (BtB) activities could increase the cost of goods between 2 and 15\%. ${ }^{5}$ On the other hand, Duval and Utoktham (2009) found that a 5\% decrease in the cost of imports in the importing country can increase bilateral import by $1.5 \%$ while a similar reduction in the cost of exporting can increase bilateral exports by $4.2 \%$. Wilson (2007) found that a $10 \%$ reduction in the time at the border of the importer can increase trade by $6.3 \%$, while a $10 \%$ reduction in the number of documents required by the importer could generate an $11.1 \%$ increase in trade. Similar studies by others further confirm this relationship. ${ }^{6}$ More generally, the benefit of reforms in trade facilitation has outweighed the cost and is often characterized by a relatively short term payback period (Engman, 2005).

Reducing and streamlining the BtB activities need not be similar across countries, as specific circumstances, needs and capacities of individual implementing countries should be taken into account. Nevertheless, simplifying and standardizing border procedures, assessing and managing the risks of border control violation more efficiently, and closer co-operation among Customs authorities are considered to be trade facilitation measures that can result in significant reduction in the cost of doing international trade.

Trade facilitation in China is not as severe as some of the other large emerging economies. A snap-shot of China's position in the World Bank's Doing Business 2010 ranking is testimony to this fact. In 2010, China moved 5 positions up to 44 in the Trading Across Borders category. More specifically, the documents involved, time and costs in most cases were better or equivalent to the East Asia \& Pacific average. See Table 2. Comparing the relative time and costs over the period of the World Bank study seem to indicate that China has reached a saturation level i.e. number of documents and time to import and export has remained stagnant since $2007 .{ }^{7}$ See Table 3. However, a comparison with the leader of the rankings (Singapore) shows the potential for improvements, particularly in the time involved in BtB activities.

Another World Bank study that provides some indications of TF in China (and worldwide) is the Logistical Performance Index (LPI). This index is based on surveys conducted among logistics professionals and "provides a comprehensive picture of supply chain performance-from customs procedures, logistics costs, and infrastructure quality to the ability to track and trace shipments, timeliness in reaching destination, and the competence of the domestic logistics industry". 8

\footnotetext{
${ }^{5}$ Ibid

${ }^{6}$ See Appendix 1 for other studies and key findings.

${ }^{7}$ Although the cost to export and import show an upward trend, this may be due to the general increase in price levels rather than an increase in costs.

${ }^{8}$ World Bank (2010), Connecting to Compete 2010: Trade Logistics in the Global Economy, www .worldbank.org
} 
Table 2. Trading Across Borders 2010: China

\begin{tabular}{|l|c|c|c|}
\hline Indicator & China & East Asia \& Pacific & OECD Average \\
\hline $\begin{array}{l}\text { Documents to } \\
\text { export(number) }\end{array}$ & 7 & 6.7 & 4.3 \\
\hline Time to export(days) & 21 & 23.1 & 10.5 \\
\hline $\begin{array}{l}\text { Cost to export(US\$ per } \\
\text { container) }\end{array}$ & 500 & 909.3 & $1,089.70$ \\
\hline $\begin{array}{l}\text { Documents to } \\
\text { import(number) }\end{array}$ & 5 & 7.1 & 4.9 \\
\hline Time to import(days) & 24 & 24.3 & $11,145.90$ \\
\hline $\begin{array}{l}\text { Cost to import(US\$ per } \\
\text { container) }\end{array}$ & 545 & 952.8 & \\
\hline
\end{tabular}

Source: World Bank (2010), Doing Business 2010, www.worldbank.org.

Table 3: Trading across Borders, 2006-2010

\begin{tabular}{|c|c|c|c|c|c|c|}
\hline & Year & 2006 & 2007 & 2008 & 2009 & 2010 \\
\hline Ease of I & ng Business Rank & & & & 86 & 89 \\
\hline Trading & Rank & & & & 49 & 44 \\
\hline $\begin{array}{l}\text { Across } \\
\text { Border }\end{array}$ & $\begin{array}{l}\text { Documents to } \\
\text { export(number) }\end{array}$ & 6 & 7 & 7 & 7 & 7 \\
\hline & Time to Export(days) & 18 & 21 & 21 & 21 & 21 \\
\hline & $\begin{array}{l}\text { Cost to export(US\$ per } \\
\text { container) }\end{array}$ & 335 & 390 & 390 & 460 & 500 \\
\hline & $\begin{array}{l}\text { Documents to } \\
\text { import(number) }\end{array}$ & 11 & 6 & 6 & 6 & 6 \\
\hline & Time to import(days) & 24 & 24 & 24 & 24 & 24 \\
\hline & $\begin{array}{l}\text { Cost to import (US\$ per } \\
\text { container) }\end{array}$ & 375 & 430 & 430 & 545 & 545 \\
\hline
\end{tabular}

Source: World Bank (2010), Doing Business 2010, www.worldbank.org.

Table 4 reports the performance of China vis-à-vis other selected countries. On the whole, China's performance is below the regional average (3.31 compared to 2.58) with the worst performance in customs procedures. The scores are not significantly different from Malaysia and Thailand but marginally better than other large emerging economies like India and Indonesia. Previous surveys of LPI (2007) as shown in Table 5 provide further confirmation that the bottleneck seems to be in customs procedures. In particular, respondents raised issues concerning the transparency of customs clearance where only about a third agreed that such activities are transparent. In addition, the quality of service provided by customs brokers, transport associations and shipping agencies are also considered low. However, a majority of those surveyed agreed that improvements have been made since 2005 with regards to the clearance procedures of the China Customs. 
Table 4: Logistics Performance Index (LPI)

\begin{tabular}{|c|c|c|c|c|c|c|c|}
\hline Country & LPI & Customs & Infrastructure & $\begin{array}{l}\text { International } \\
\text { shipment }\end{array}$ & $\begin{array}{l}\text { Logistics quality } \\
\text { \& competence }\end{array}$ & $\begin{array}{l}\text { Tracking\& } \\
\text { tracing }\end{array}$ & Timeliness \\
\hline Malaysia & 3.44 & 3.11 & 3.5 & 3.5 & 3.34 & 3.32 & 3.86 \\
\hline Thailand & 3.29 & 3.02 & 3.16 & 3.27 & 3.16 & 3.41 & 3.73 \\
\hline China & 3.49 & 3.16 & 3.54 & 3.31 & 3.49 & 3.55 & 3.91 \\
\hline Vietnam & 2.96 & 2.68 & 2.56 & 3.04 & 2.89 & 3.1 & 3.44 \\
\hline Indonesia & 2.76 & 2.43 & 2.54 & 2.82 & 2.47 & 2.77 & 3.46 \\
\hline India & 3.12 & 2.7 & 2.91 & 3.13 & 3.16 & 3.14 & 3.61 \\
\hline Sri Lanka & 2.29 & 1.96 & 1.88 & 2.48 & 2.09 & 2.23 & 2.98 \\
\hline Cambodia & 2.37 & 2.28 & 2.12 & 2.19 & 2.29 & 2.5 & 2.84 \\
\hline Bangladesh & 2.74 & 2.33 & 2.49 & 2.99 & 2.44 & 2.64 & 3.46 \\
\hline Nepal & 2.2 & 2.07 & 1.8 & 2.21 & 2.07 & 2.26 & 2.74 \\
\hline Note:1-very low; 5-very high
\end{tabular}

In an earlier Artnet study by Chen and Li (2006) on trade facilitation in China, the private sector listed three most important areas for improvement, namely: 1) the elimination of bribery and other corrupt practices of officials involved at the clearance and release of imported goods; 2) the completion of clearance of goods before they have arrived physically in the Customs territory; and 3) the improvement of coordination between relevant agencies, particularly on document requirements. The problems faced behind-the-border differs in some way between foreign firms and local firms. Greene and Tsai (2008) found that clear and transparent rules for customs procedures, predictable and impartial procedures as well as pressures for illegal payments were more of an issue for foreign (OECD) firms than their local counterparts.

On the part of China Customs, there have been continuous improvements in clearance procedures as well as pilot projects on the use of ICT to speed up and standardize the relevant procedures. These include a paperless customs clearance; one declaration, one inspection and one clearance process to facilitate the movement of goods between inland cities and ports; e-customs which facilitates networking among national customs authorities; and the e-ports project which promotes the data exchange and joint inspection of various government departments. ${ }^{9}$

\footnotetext{
${ }^{9}$ http://www.unescap.org/tid/artnet/mtg/consult2_s4china.pdf; http://www.cfea.org.cn/news/down.asp?upfile=73229122008105014_1.DOC\&upname=\%BD\%B9\%BD\% A8\%C8\%BA\%B7\%A2\%D1\%D4\%B8\%E5-\%D3\%A21201.doc
} 


\section{Table 5: LPI China - Survey Results}

\begin{tabular}{|c|c|}
\hline \multicolumn{2}{|l|}{ Level of Fees and Charges } \\
\hline $\begin{array}{l}\text { Based on your experience in international logistics, please select } \\
\text { the options that best describe the operational logistics environment } \\
\text { in your country of work }\end{array}$ & $\begin{array}{c}\text { Percent of respondents answering } \\
\text { high/very high }\end{array}$ \\
\hline & China \\
\hline Port charges are & $38.10 \%$ \\
\hline Airport charges are & $23.81 \%$ \\
\hline Road transport rates are & $23.81 \%$ \\
\hline Rail transport rates are & $16.67 \%$ \\
\hline Warehousing/transloading charges are & $20 \%$ \\
\hline Agent fees are & $33.33 \%$ \\
\hline \multicolumn{2}{|l|}{ Quality of Infrastructure } \\
\hline \multirow[t]{2}{*}{$\begin{array}{l}\text { Evaluate the quality of trade and transport related infrastructure } \\
\text { (e.g. ports, roads, airports, information technology) in your } \\
\text { country of work }\end{array}$} & $\begin{array}{c}\text { Percent of respondents answering } \\
\text { low/very low }\end{array}$ \\
\hline & China \\
\hline Ports & 0 \\
\hline Airports & $4.76 \%$ \\
\hline Roads & $31.82 \%$ \\
\hline Rail & $55.00 \%$ \\
\hline Warehousing/transloading facilities & $33.33 \%$ \\
\hline Telecommunications and IT & $31.82 \%$ \\
\hline \multicolumn{2}{|l|}{ Competence and Quality of Services } \\
\hline \multirow[t]{2}{*}{$\begin{array}{l}\text { Evaluate the competence and quality of service delivered by the } \\
\text { following in your country of work }\end{array}$} & $\begin{array}{c}\text { Percent of respondents answering } \\
\text { high/very high }\end{array}$ \\
\hline & China \\
\hline Road & $19.05 \%$ \\
\hline Rail & $14.29 \%$ \\
\hline Air transport & $42.86 \%$ \\
\hline Maritime transport & $52.38 \%$ \\
\hline Warehousing/transloading and distribution & $19.05 \%$ \\
\hline Freight forwarders & $47.62 \%$ \\
\hline Customs agencies & $23.53 \%$ \\
\hline Quality/standards inspection agencies & $14.29 \%$ \\
\hline Health/SPS agencies & $14.29 \%$ \\
\hline Customs brokers & $9.52 \%$ \\
\hline Trade and transport associations & $9.52 \%$ \\
\hline Consignees or shippers & $9.52 \%$ \\
\hline
\end{tabular}




\section{Efficiency of Processes}

Evaluate the efficiency of the following processes in your country of work

Percent of respondents answering often or nearly always efficient

\begin{tabular}{l|c} 
& China \\
\hline Clearance and delivery of imports & $57.14 \%$ \\
\hline Clearance and delivery of exports & $76.19 \%$ \\
\hline $\begin{array}{l}\text { Transparency of customs clearance } \\
\text { Provision of adequate and timely information on regulatory }\end{array}$ & $\mathbf{3 5 . 2 9 \%}$ \\
\hline $\begin{array}{l}\text { Expedited customs clearance for traders with high compliance } \\
\text { levels }\end{array}$ & $28.57 \%$ \\
\hline
\end{tabular}

\section{Sources of Major Delays}

How often in your country of work, you experience

Percent of respondents answering often or nearly always

\section{China}

Compulsory warehousing/transloading

0

Pre-shipment inspection

$5.26 \%$

Maritime transshipment

$5.26 \%$

Criminal activities (e.g., stolen cargo)

Solicitation of informal payments

0

Changes in the Logistics Environment Since 2005

Since 2005, have the following factors improved or worsened in your country of work

Percent of respondents answering improved or much improved

\section{Customs clearance procedures}

China

Other official clearance procedures

$68.42 \%$

Trade and transport infrastructure

$52.63 \%$

Telecommunications and IT infrastructure

$84.21 \%$

Private logistics services

Regulation related to logistics

$78.95 \%$

Incidence of corruption

$83.33 \%$

$68.42 \%$

$33.33 \%$

Source: World Bank (2007), Connecting to Compete 2007: Trade Logistics in the Global Economy 


\section{Trade Facilitation in China - A Business Process Analysis $(B P A)$}

Previous research on trade facilitation in China has taken a macro and/or a survey based approach. The objective of the current study is to drop one level lower to evaluate in detail the processes involved in the export and import of goods. By employing the BPA methodology ${ }^{10}$, one is able to trace all the steps and procedures involved in the process and consider the time and cost involved in each one of these steps. The BPA is carried out using a case study approach which allows for an in-depth analysis of the process and challenges faced by firms behind the border. In this way, the researcher is able to "follow" goods and documents from one stakeholder to another i.e. from the warehouse of the exporter to the warehouse of the exporter. On completion of the mapping of the trade process, one is then able to identify areas where bottlenecks and duplication occur and propose possible solutions.

The project identified 4 products and two countries for the in-depth analysis. To map export procedures, the project will focus on garment and electronic exports to Japan and Thailand, while for imports, textiles and automobile parts from Japan has been the focus of analysis.

The choice of the 4 product categories is meaningful vis-à-vis Japan. Table 6 shows that Japan is the leading export destination of China's garments. Since 2005, Japan has also been the leading source of textiles import (Table 7). Table 8 shows that in 2008, Japan accounted for more than $40 \%$ of China's imports of automotive products, and has accounted for more than a third since 2005. In the case of electronics, Thailand is a fairly important export destination in Southeast Asia for Chinese electronics goods (Table 9). The inclusion of Thailand into the project is due to the recent establishment of the ChinaASEAN FTA which came into effect on $1^{\text {st }}$ January 2010.

A total of 4 case studies were carried out in this project. This was to ensure that information collected for the mapping process was from at least 2 companies for each trade direction. The companies differ such that we have a combination of large and small exporters/importers. A summary of the companies interviewed for this project is provided in Table 10.

\footnotetext{
${ }^{10}$ See UNESCAP (2009), Business Process Analysis Guide to Simplify Trade Procedures, for further details.
} 
Table 6. Top 5 Garments Export Destination of China

\begin{tabular}{|r|c|c|c|c|c|}
\hline 2005 & Japan & USA & Hong Kong SAR & Germany & Russia \\
\hline & $21.48 \%$ & $17.79 \%$ & $9.73 \%$ & $4.16 \%$ & $3.99 \%$ \\
\hline 2006 & Japan & USA & Hong Kong SAR & Romania & Germany \\
\hline & $17.12 \%$ & $16.01 \%$ & $9.78 \%$ & $5.60 \%$ & $3.68 \%$ \\
\hline 2007 & USA & Japan & Hong Kong SAR & Russia & Germany \\
\hline & $15.36 \%$ & $14.62 \%$ & $8.19 \%$ & $7.77 \%$ & $4.02 \%$ \\
\hline & Japan & USA & Hong Kong SAR & Germany & Russia \\
\hline & $15.02 \%$ & $14.47 \%$ & $6.47 \%$ & $5.21 \%$ & $4.71 \%$ \\
\hline
\end{tabular}

Source: UN comtrade

\section{Table 7. Top 5 Sources of Textiles Imports}

\begin{tabular}{|c|c|c|c|c|c|}
\hline \multicolumn{6}{|c|}{ Import of textile (HS code 50-60, 57 not included) } \\
\hline \multirow[t]{2}{*}{2005} & Japan & Rep. of Korea & USA & Australia & Hong Kong SAR \\
\hline & $16.42 \%$ & $12.69 \%$ & $9.53 \%$ & $6.12 \%$ & $0.05 \%$ \\
\hline \multirow[t]{2}{*}{2006} & Japan & USA & Rep. of Korea & Australia & Hong Kong SAR \\
\hline & $14.53 \%$ & $12.39 \%$ & $10.85 \%$ & $5.69 \%$ & $4.87 \%$ \\
\hline \multirow[t]{2}{*}{2007} & Japan & Rep. of Korea & USA & Australia & Hong Kong SAR \\
\hline & $14.72 \%$ & $10.89 \%$ & $10.18 \%$ & $7.07 \%$ & $4.78 \%$ \\
\hline \multirow[t]{2}{*}{2008} & Japan & USA & Rep. of Korea & Australia & India \\
\hline & $15.32 \%$ & $11.23 \%$ & $10.50 \%$ & $6.57 \%$ & $5.25 \%$ \\
\hline \multirow[t]{2}{*}{2009} & Japan & Rep. of Korea & USA & Australia & Pakistan \\
\hline & $15.19 \%$ & $10.76 \%$ & $8.38 \%$ & $6.26 \%$ & $4.69 \%$ \\
\hline
\end{tabular}

Source: UN Comtrade

Table 8: Automotive Products - China’s Main Import Sources

\begin{tabular}{|c|c|c|c|c|c|c|c|c|c|c|}
\hline 2005 & Japan & Germany & $\begin{array}{l}\text { Rep. of } \\
\text { Korea }\end{array}$ & $\begin{array}{c}\text { Other } \\
\text { Asia }\end{array}$ & France & Sweden & Australia & Canada & Brazil & Italy \\
\hline & $37.85 \%$ & $26.02 \%$ & $18.61 \%$ & $3.06 \%$ & $2.97 \%$ & $2.37 \%$ & $1.42 \%$ & $1.14 \%$ & $0.66 \%$ & $0.61 \%$ \\
\hline \multirow[t]{2}{*}{2006} & Japan & Germany & $\begin{array}{l}\text { Rep. of } \\
\text { Korea }\end{array}$ & France & $\begin{array}{l}\text { Other } \\
\text { Asia }\end{array}$ & Sweden & Slovakia & Mexico & Canada & Austria \\
\hline & $34.57 \%$ & $33.50 \%$ & $13.77 \%$ & $3.74 \%$ & $2.08 \%$ & $2.05 \%$ & $1.38 \%$ & $1.29 \%$ & $1.21 \%$ & $0.96 \%$ \\
\hline \multirow[t]{2}{*}{2007} & Japan & Germany & $\begin{array}{c}\text { Rep. of } \\
\text { Korea }\end{array}$ & $\begin{array}{c}\text { Slovak } \\
\text { ia }\end{array}$ & France & Sweden & $\begin{array}{l}\text { Other } \\
\text { Asia }\end{array}$ & Mexico & Canada & Austria \\
\hline & $37.96 \%$ & $33.52 \%$ & $10.65 \%$ & $2.97 \%$ & $2.88 \%$ & $2.13 \%$ & $1.33 \%$ & $1.08 \%$ & $1.06 \%$ & $0.98 \%$ \\
\hline \multirow[t]{2}{*}{2008} & Japan & Germany & $\begin{array}{c}\text { Rep. of } \\
\text { Korea }\end{array}$ & $\begin{array}{c}\text { Slovak } \\
\text { ia }\end{array}$ & France & Sweden & Austria & $\begin{array}{l}\text { Other } \\
\text { Asia }\end{array}$ & Italy & Mexico \\
\hline & $41.06 \%$ & $34.26 \%$ & $8.78 \%$ & $3.26 \%$ & $1.92 \%$ & $1.78 \%$ & $1.02 \%$ & $0.98 \%$ & $0.87 \%$ & $0.85 \%$ \\
\hline
\end{tabular}

Source: UN Comtrade 


\section{Table 9: China's Exports of Electronics to Southeast Asia, proportion of total exports}

\begin{tabular}{|c|c|c|c|c|}
\hline \multicolumn{5}{|c|}{ Export of electronics } \\
\hline & 2005 & 2006 & 2007 & 2008 \\
\hline Thailand & $0.98 \%$ & $0.98 \%$ & $0.88 \%$ & $0.90 \%$ \\
\hline Malaysia & $1.53 \%$ & $1.51 \%$ & $1.61 \%$ & $1.50 \%$ \\
\hline Indonesia & $0.66 \%$ & $0.64 \%$ & $0.71 \%$ & $0.93 \%$ \\
\hline Philippines & $0.86 \%$ & $0.76 \%$ & $0.73 \%$ & $0.72 \%$ \\
\hline Viet Nam & $0.21 \%$ & $0.29 \%$ & $0.47 \%$ & $0.57 \%$ \\
\hline Singapore & $3.86 \%$ & $4.25 \%$ & $3.48 \%$ & $2.97 \%$ \\
\hline
\end{tabular}

Source: UN Comtrade

Table 10. Case Studies

\begin{tabular}{|l|l|l|l|}
\hline Trade Direction & Products & Japan & Thailand \\
\hline Exports & Garments & Company X & \\
\hline Imports & Electronics & & Company M \\
\hline & Automotive Parts & Company P & \\
\hline & Textiles & Company X & \\
\hline
\end{tabular}

A brief profile of the companies is provided below:

Company $\mathrm{M}$ is China's leading electronic appliance company, based in the southern Guangdong Province. Its main products are air-conditioners, refrigerators, microwaves, and so on. The company owns the largest and most complete industry chains of air-conditions, microwaves, washing machines, and refrigerators in China. In mid- 2009, the top 10 largest shareholders own $58.7 \%$ of the total shares with a majority being funds including a well-known US university. The net profit in the first 3 quarters of 2009 was nearly 405 million RMB. Revenue from international markets makes up more than a third of its total revenue. The company now exports its products with own brand in Asia and Europe but is only an OEM in the US market. It is a main supplier of K-Mart, Home-Depot and Sears. In 2007, the company opened its first overseas base in Vietnam. For the purpose of this study, we will evaluate the company's exports to Thailand.

Company $\mathrm{X}$ is a garment company located in Pinghu city, Zhejiang province. Established in 1997, its main products are casual suits and sporting garments. The current export volume is above USD 6 million, mainly to Japan, America and Europe. The company employs more than 2800 people and over 3000 sets of equipments. It has a production capacity exceeding 6 million pieces. The company has the ISO 14000 and ISO 9000 accreditation and was awarded as the "National top 500 private enterprises". For the purpose of this study, the company's export of garments and the imports of textiles to and from Japan are considered. 
Company $\mathrm{P}$ is an automobile parts producer located in YangZhou city, JiangSu province. Established in 1993, its main products are power metal mechanical parts. The company is a joint venture between a Chinese power metal company and a Taiwanese group. Currently, Company $\mathrm{P}$ is a leading company of power metal parts in China. The annual sales are about RMB 800 million. Its main customers are automobile OEMs and first tier components providers, such as Ford, VW, Magna etc. The company has the ISO 14000, ISO 9000 and TS 16949 accreditation and was awarded the "National Top Hi-tech Enterprise". For the purpose of this study, the company's import from Japan is considered.

In addition to the 4 cases, the verification of the trade process maps was discussed with a forwarding agency and a customs broker.

\section{Export Process Analysis for Selected Products}

\section{Export of Garments to Japan}

In 2008, Japan was the destination of nearly $15 \%$ of total textile and garment exports of China. Being a developed market, Japan is obviously an attractive destination for small and large Chinese enterprises. For the purpose of this project, we examined the export process of a medium sized company, Company $\mathrm{X}$. The company has been exporting to Japan since 1992, and on average exports 1000 20-foot container load worth of garments to Japan every year.

The complete process of exporting is mapped out using the BPA methodology and shown in Appendix 2. The process involves 9 distinct steps:

1. Buy: This process involves the negotiations between Company $X$ and its Japanese client. The steps involve negotiation of price and payment term (e.g. CIF or FOB). Upon acceptance by both parties, the sample garment is confirmed and a purchasing contract is signed. The entire process could be done electronically, and there is no fee as such in this process. Due to the long-term relationship that Company $X$ has with its Japanese client, the process takes no more than a day. From the time the contract is signed to the preparation of the shipment of goods, it may take 1-6 months, depending on the volume of the shipment, complexity, etc.

2. Arrange Transport: When the order is close to completion, shipping arrangements need to be confirmed. The company uses a customs broker to liaise with the shipping company. It provides the broker with some basic information like destination, quantity, date of shipment etc. When the suitable vessel has been found, the broker makes the booking request and confirms the shipping details and shipping cost. Finally, a shipping order is issued. The fee charged by the broker including arranging transport, inland transport, customs documentation fee etc. is between RMB2000-3000. A higher range fee may be charged during peak periods and/or if the shipment is subject to extensive inspections etc. The entire process takes between 2-3 days, depending on the availability of the vessel. Communications are electronic. 
3. Arrange for Inspection: Company $X$ now needs to request for an inspection of its garments by the local Entry-Exit Inspection and Quarantine Bureau (or Commercial Inspection Bureau. The inspection focuses on issues like quality, safety, toxicity of goods etc. Eight documents needs to be provided, following which an inspection schedule is confirmed. Among the documents is a customs declaration form that is downloaded online which must be filled up by Company $X$ (or the customs broker based on the information provided by the company). The approval of the customs declaration form is also done online. This must then be printed for the inspection. The export registry book (or referred to as the blue book) records all input that has been imported and utilized for the manufacture of the export shipment. Since the importation of input for export purposes is duty free, the company needs to show that all imported input has been utilized to produce final goods for export. Any surplus in imported inputs would either be charged the prevailing duty or confiscated by the customs department at the end of the specified period. The components card comprises of a sample of all input (fabric, buttons, zippers etc) that has been used in the manufacture of the exported shipment. A copy of the Letter of Credit (LC) is also provided if the nature of payment is through an LC. For orders from long term clients, telegraphic transfers could also be used. This may take up to 2 days, although the inspection itself is done within half a day. The inspection is done randomly (i.e. there are times when approval is given without inspection) and a fee of $0.15 \%$ of total goods value is charged. A certificate of commodity inspection is issued and the customs declaration form is stamped by the local inspection bureau.

4. Obtain Cargo Insurance: Information regarding the market value of goods and shipping information is provided so that insurance cover can be secured. The premium ranges between $0.3-0.5 \%$ of sum insured. This process is done within a day. The company has a long term relationship with the insurance agent, and so the insurance covers all shipment over one year, rather than on a per shipment basis.

5. Collect Empty Container from Yard: On the day that the goods are to be loaded into the container, the customs broker will instruct the internal transportation company to pick the container from the yard. The shipping company is informed and the assigned container is made available to the internal transportation company.

6. Stuff the container: Goods are loaded on to the container within a day.

7. Transportation to Port of Departure: The sealed container is transported to the port, and checked by the shipping company at the entrance to the port. Company $X$ uses the Shanghai port, which is about 1-1.5 hours away from the warehouse. The container is docked at the required site for inspection.

8. Customs Inspection and Clearance: The container undergoes scanning, and upon the request of the customs officers, the container is opened for scrutiny. Having cleared this process, the relevant documents are verified. In addition to the documents explained earlier, Company $X$ must issue a letter entrusting the customs broker to act on its behalf. If the inspection and documents are approved, a green light note is issued. This process takes not more than one day.

9. Container Handling: The green light note is then passed to the shipping company or its agent who will then make a plan on where the container will be stowed. The port authority will then stow the container according to this plan. 
10. Prepare Documents for Importer: Upon the receipt of the Bill of Lading, together with the Commercial Invoice and Finished Goods Inspection Certificate (by $3^{\text {rd }}$ Party, or sometimes by Company $X$ ), the documents are mailed to the Japanese client.

11. Pay: All documents required in the LC - Invoice, Packing List, Bill of Lading etc. - are submitted to the Bank. The Bank charges the company $0.1 \%$ of the LC amount as charges. Collecting all necessary documents for the payment application takes less than a day but it may take up to 15 days to receive payment from the Bank.

The processes, actors and documents involved are shown in Table 11. Figure 2 summarizes the number of days each process takes. Company $X$ spends a total of 10 days for the trade facilitation process (not including one day for finalizing contracts). It takes about 15 days for payment to be received. A total of 15 documents are required, and a cost between RMB 2000-3000 is incurred (not including shipping cost).

\section{Table 11. Exporting Garments to Japan - Company X}

\begin{tabular}{|c|c|c|c|}
\hline Major Steps & Documents & Actors & Days \\
\hline Buy & - Sales contract & - Importer and Exporter & 1 \\
\hline Arrange transport & - $\quad$ Shipping Order & $\begin{array}{ll}\text { - } & \text { Exporter } \\
\text { - } & \text { Shipping Company } \\
& \text { Bustoms } \\
& \text { Broker（报关行） }\end{array}$ & 3 \\
\hline Arrange Inspection & $\begin{array}{ll}\text { - } & \text { Commercial Invoice } \\
\text { - } & \text { Customs declaration } \\
\text { - } & \text { Export Register Book } \\
\text { - } & \text { Components card } \\
\text { - } & \text { Packing List } \\
\text { - } & \text { Letter of Credit } \\
\text { - } & \text { Wash label } \\
\text { - } & \text { Sales Contract }\end{array}$ & $\begin{array}{ll}\text { - } & \text { Exporter } \\
\text { - } & \text { Commodity Inspection } \\
& \text { Bureau(进出口商品检 } \\
\text { 验局 })\end{array}$ & 2 \\
\hline Obtain cargo insurance & - Commercial Invoice & $\begin{array}{ll}\text { - } & \text { Exporter } \\
\text { - } & \text { Insurance Company }\end{array}$ & 1 \\
\hline $\begin{array}{l}\text { Collect empty containers } \\
\text { from yard }\end{array}$ & - $\quad$ Shipping Order & $\begin{array}{ll}\text { - } & \text { Exporter } \\
\text { - } & \text { Shipping Company, } \\
\text { Transportation } \\
\text { company } \\
\text { - } \quad \text { Customs Broker }\end{array}$ & 1 \\
\hline Stuff containers & - $\quad$ Packing List & $\begin{array}{ll}\text { - } & \text { Exporter } \\
\text { - } & \text { Transportation } \\
\text { company }\end{array}$ & \\
\hline $\begin{array}{l}\text { Transfer to port of } \\
\text { departure }\end{array}$ & $\bullet$ & $\begin{array}{ll}\text { - } & \text { Transportation } \\
& \text { company } \\
\text { - } & \text { Shipping Company }\end{array}$ & 1 \\
\hline $\begin{array}{l}\text { Clear goods through } \\
\text { customs }\end{array}$ & $\begin{array}{ll}\text { - } & \text { Commercial Invoice } \\
\text { - } & \text { Exporter Register Book } \\
\text { - } & \text { Customs declaration } \\
& \text { Certificate of } \\
& \text { commodity inspection } \\
\text { - } & \text { Packing List }\end{array}$ & $\begin{array}{ll}\text { - } & \text { Customs Broker } \\
\text { - } & \text { Shipping Company } \\
\text { - } & \text { Customs Department }\end{array}$ & \\
\hline
\end{tabular}




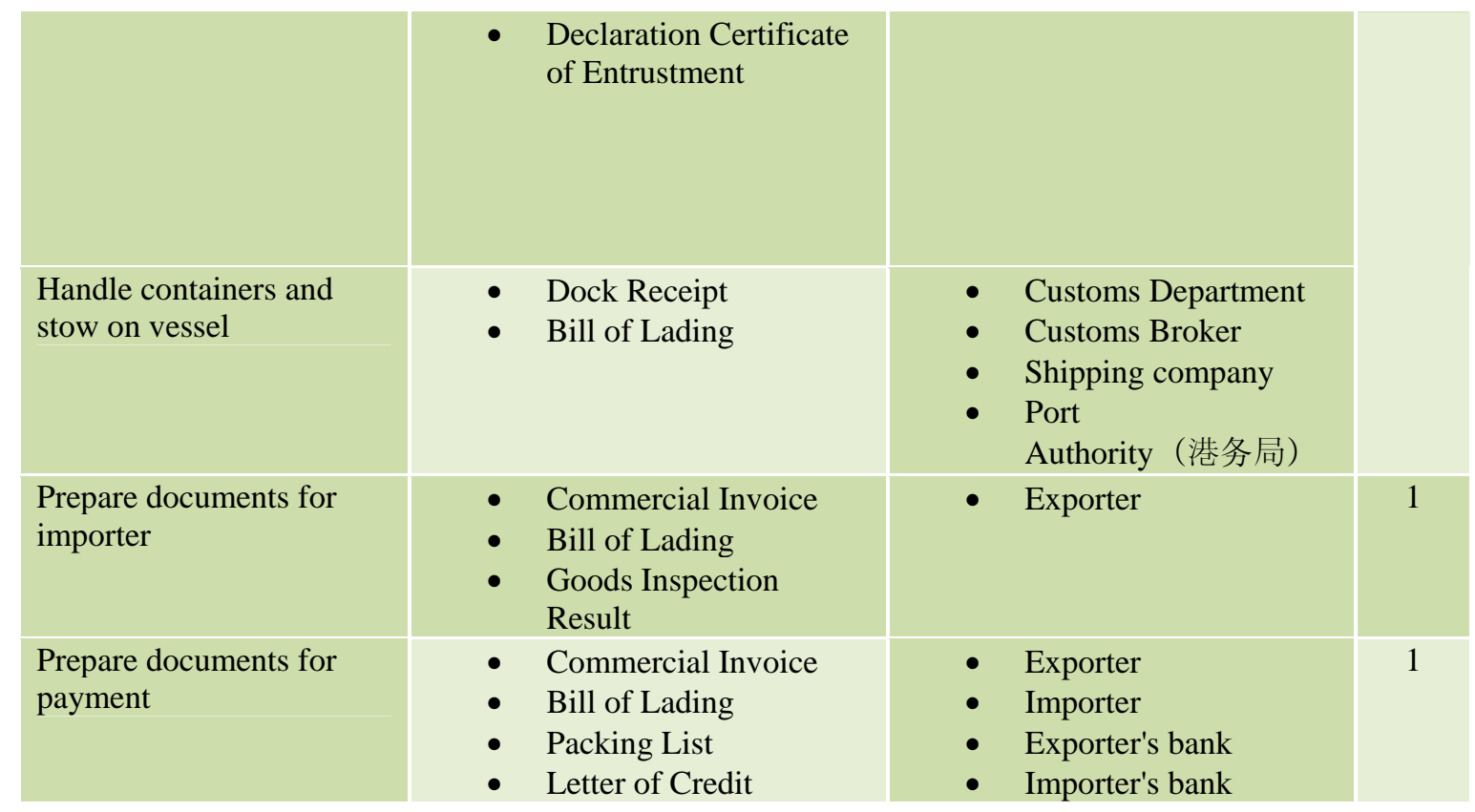

\section{Figure2: The Time-procedure Chart of Garments from China}

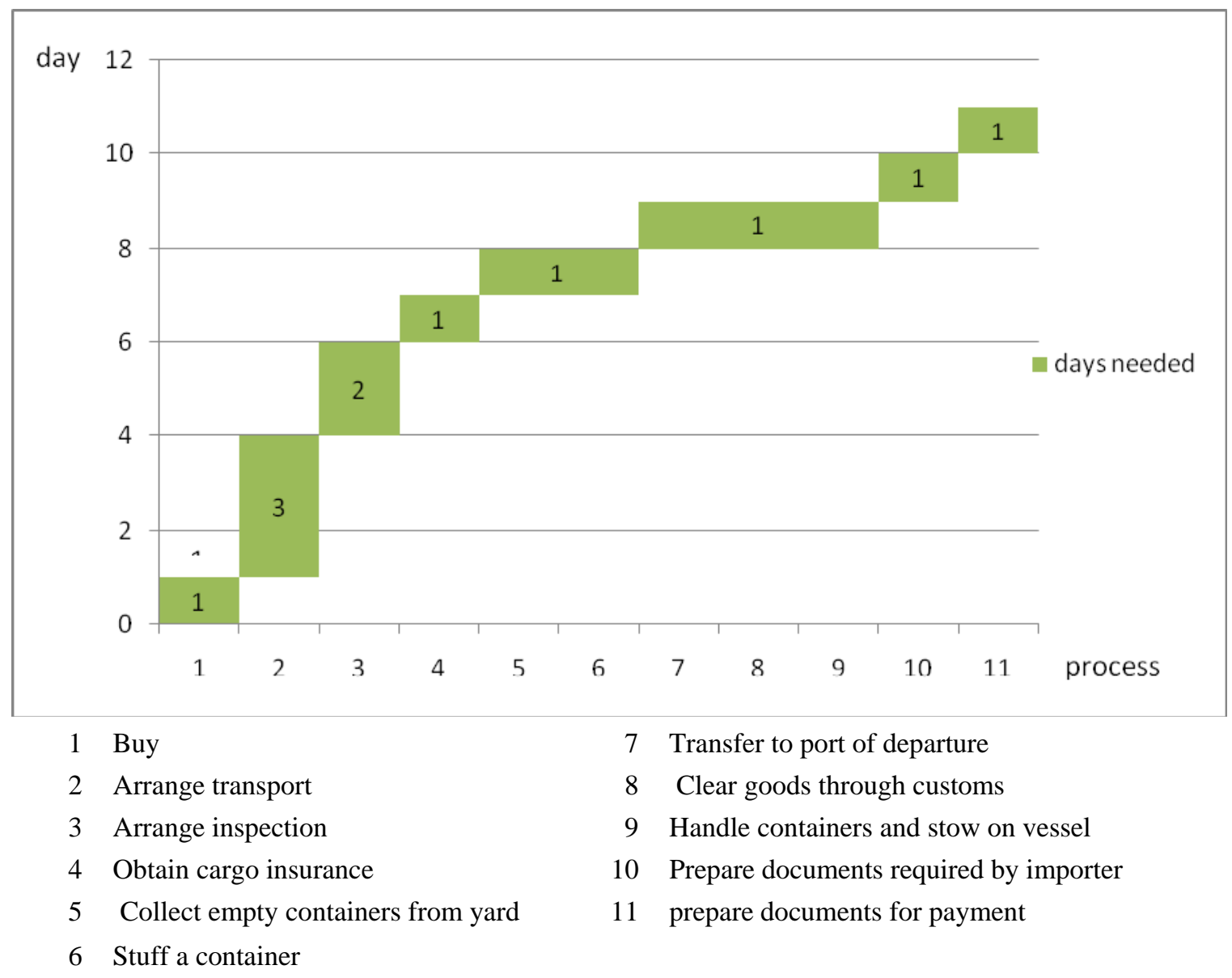




\section{Export of Electronic Products to Thailand}

Although China only exports only less than $1 \%$ of its electronic products to Thailand, for the purpose of this project, we consider the export activities of a large Chinese electronic manufacturer, Company M. The company exports its own brand name product to Thailand. It must be noted here that Thailand is not one of Company M's significant market, and so sometimes the company uses a freight forwarder or customs broker to handle customs issues. A complete process of this export activity is shown in Appendix 3.

The following are the processes involved in the exports of electronics to Thailand:

1. Buy: The client places an order via email which is then entered into Company M's Esystem. A pro-forma invoice is provided to the client. Once the order is approved by the relevant managers, the manufacturing process starts. Alternatively, if stocks are available, the goods are ready to be shipped. The entire process can take 2-3 days.

2. Export Permit: The Company applies for the export permit online. It provides the necessary information (destination port, unit numbers, gross weight etc.) and a permit is issued when approved. Company M claims that it may take between 4 to 7 days for this process. Since the company is large exporter, the inspection of goods takes place even before manufacture is complete. For mature products, the inspection is done once in 3-4 months by the Commodity Inspection Bureau, while for new products inspection is done once every 1-2 months. Officers from the Bureau will randomly select some products for quality and safety inspection, either at the company's premises or the Bureau's laboratories. Thus, the inspection is not based the order, rather one that is done randomly.

3. Arrange Sea Transport: Booking the vessel for the export to Thailand should be done about 2-7 days in advance. This is done simultaneously with export permit application.

4. Inspection by Client: In some cases, inspection of the order is required by the client. This is either done by the client's branch office in China or a third party. Inspection will take a day, and an inspection certificate is issued to the company if all requirements have been met.

5. Prepare for Customs Declaration: Company $M$ needs to prepare the packing list, shipping order, purchase order, inspection certificate, the HS Code, and the invoice.

6. Collect Empty Container: The company informs the inland transportation company to collect the empty container that has been assigned by the shipping company. This is done on the same day as the stuffing and customs clearance.

7. Stuff container: A packing list is provided here to ensure all goods have been stuffed.

8. Transport to Port: Company M uses two ports - Shenzhen and Foshan. The choice of port depends on where the ship is berthed. For shipments to Europe and the US, this is mainly done through Shenzhen. For smaller shipments, Foshan is used. The necessary documents are handed to the inland transportation company (truck driver). 
9. As the company is large exporter, the customs clearance process is done within a day. The container is scanned and if required, it is required to be opened for closer scrutiny. The necessary documents are verified, and a green light note is issued, with which the container is ready to be stowed.

10. Handle Container and Stow on Vessel: The green light note is then passed to the shipping company or its agent who will then make a plan on where the container will be stowed. The port authority will then stow the container according to this plan.

11. Obtain Cargo Insurance: Insurance is applied online. Payment for insurance cover is done every six months.

12. Prepare Documents for Client: Among the documents prepared for the client is the Verification certificate which is a copy of the Electric Products Safety Certificate issued by various third party certification authorities including TRS of Thailand. These certificates are applied for the whole range of products. A copy of the certificate is provided for the client when required.

13. Prepare Documents for Payment: The necessary documents are prepared to be submitted to the Exporter's Bank for payment collection. This process does not take more than 0.5 days.

14. Pay: The client will pay Company M according to the contract.

The processes, actors and documents involved in the export of electronic products by Company $\mathrm{M}$ are shown in Table 12. Figure 3 summarizes the number of days each process takes. Company $\mathrm{M}$ spends on average a total of 16.5 days for the trade facilitation process (not including the time spent on finalizing contracts and payment period). The time take to receive payment for goods exported depends on the contract and credit terms. A total of 17 documents are required, and RMB 2000-3000 ${ }^{11}$ per container shipment is incurred (not including shipping cost).

\section{Import Process Analysis for Selected Products}

\section{Import of Fabric/ Accessories and Automobile Components from Japan}

As the processes for the imports of textiles and auto components appear to be mainly similar, we provide a single explanation for the two case studies. In 2008, Japan accounted for nearly $15 \%$ of China's total imports of textiles. In order to analyze the import procedures of fabric and accessories in the garment industry, we relied on the information provided by Company $\mathrm{X}$ since it imports significant input from Japan. In particular, the company sources fabric and accessories like zippers from Japanese suppliers.

\footnotetext{
${ }^{11}$ At exchange rate USD 1 = RMB 6.8264, the amount ranges from USD 293 - 440 per container shipment.
} 
As for automobile parts and components, Japan continues to be an important source of import. In 2008, China imported more than $40 \%$ of auto parts and components from Japan. To analyse the import procedures, we chose Company P, a ChineseTaiwanese JV as our case study.

The detailed steps involved in the importing procedures of textiles and auto parts are in Appendix 4 and 5 respectively. The import process involves 6 distinct steps:

\section{Table 12. Exporting Electronic Products to Thailand - Company M}

\begin{tabular}{|c|c|c|c|}
\hline Major Steps & Documents & Actors & Days \\
\hline Buy & $\begin{array}{l}\text { - } \quad \text { Pro-forma invoice } \\
\text { - } \quad \text { Sales Contract }\end{array}$ & - Importer and Exporter & 2.5 \\
\hline $\begin{array}{l}\text { Obtain export } \\
\text { permit }\end{array}$ & - $\quad$ Export Permit & $\begin{array}{ll}\text { - } & \text { Exporter } \\
\text { - } & \text { Commodity Inspection } \\
\text { Bureau(进出口商品检 } \\
\text { 验局) }\end{array}$ & 5.5 \\
\hline Arrange transport & - $\quad$ Shipping Order & $\begin{array}{ll}\text { - } & \text { Exporter } \\
\text { - } & \text { Shipping Company }\end{array}$ & 4.5 \\
\hline Arrange inspection & $\begin{array}{ll}\text { - } & \text { Commercial Invoice } \\
\text { - } & \text { Customs declaration } \\
\text { - } & \text { Export Register } \\
& \text { Book } \\
\text { - } & \text { Packing List } \\
\text { - } & \text { Sales Contract }\end{array}$ & $\begin{array}{ll}\text { - } & \text { Exporter } \\
\text { - } & \text { Importer } \\
\text { Private inspection } \\
\text { institute or client's } \\
\text { branch in China }\end{array}$ & 1 \\
\hline $\begin{array}{l}\text { Prepare customs } \\
\text { declaration }\end{array}$ & $\begin{array}{ll}\text { - } & \text { Packing List } \\
\text { - } & \text { Shipping Order } \\
\text { - } & \text { Purchase Order } \\
\text { - } & \text { Inspection } \\
& \text { Certificate } \\
\text { - } & \text { Sales Contract } \\
\text { - } & \text { Commercial Invoice }\end{array}$ & - Exporter & 1 \\
\hline $\begin{array}{l}\text { Collect empty } \\
\text { containers from yard }\end{array}$ & $\begin{array}{ll}\text { - } & \text { Shipping Order } \\
\text { - } & \text { Packing List }\end{array}$ & $\begin{array}{ll}\text { - } & \text { Exporter } \\
\text { - } & \text { Transportation } \\
& \text { Company } \\
\text { - } & \text { Shipping Company }\end{array}$ & 1 \\
\hline Stuff a container & - $\quad$ Packing List & $\begin{array}{ll}\text { - } & \text { Exporter } \\
\text { - } & \text { Transportation } \\
& \text { Company }\end{array}$ & \\
\hline $\begin{array}{c}\text { Transfer to port of } \\
\text { departure }\end{array}$ & & $\begin{array}{ll}\text { - } & \text { Exporter } \\
\text { - } & \text { Transportation } \\
& \text { Company }\end{array}$ & \\
\hline $\begin{array}{l}\text { Clear goods through } \\
\text { customs }\end{array}$ & $\begin{array}{ll}\text { - } & \text { Commercial Invoice } \\
\text { - } & \text { Export Register } \\
& \text { Book } \\
\text { - } & \text { Customs declaration } \\
\text { - } & \text { Inspection } \\
& \text { Certificate } \\
\text { - } & \text { Packing List } \\
\text { - } & \text { Sales Contract }\end{array}$ & $\begin{array}{ll}\text { - } & \text { Transportation } \\
& \text { Company } \\
\text { - } & \text { Exporter } \\
\text { - } & \text { Shipping Company } \\
\text { - } & \text { Customs Department }\end{array}$ & \\
\hline
\end{tabular}




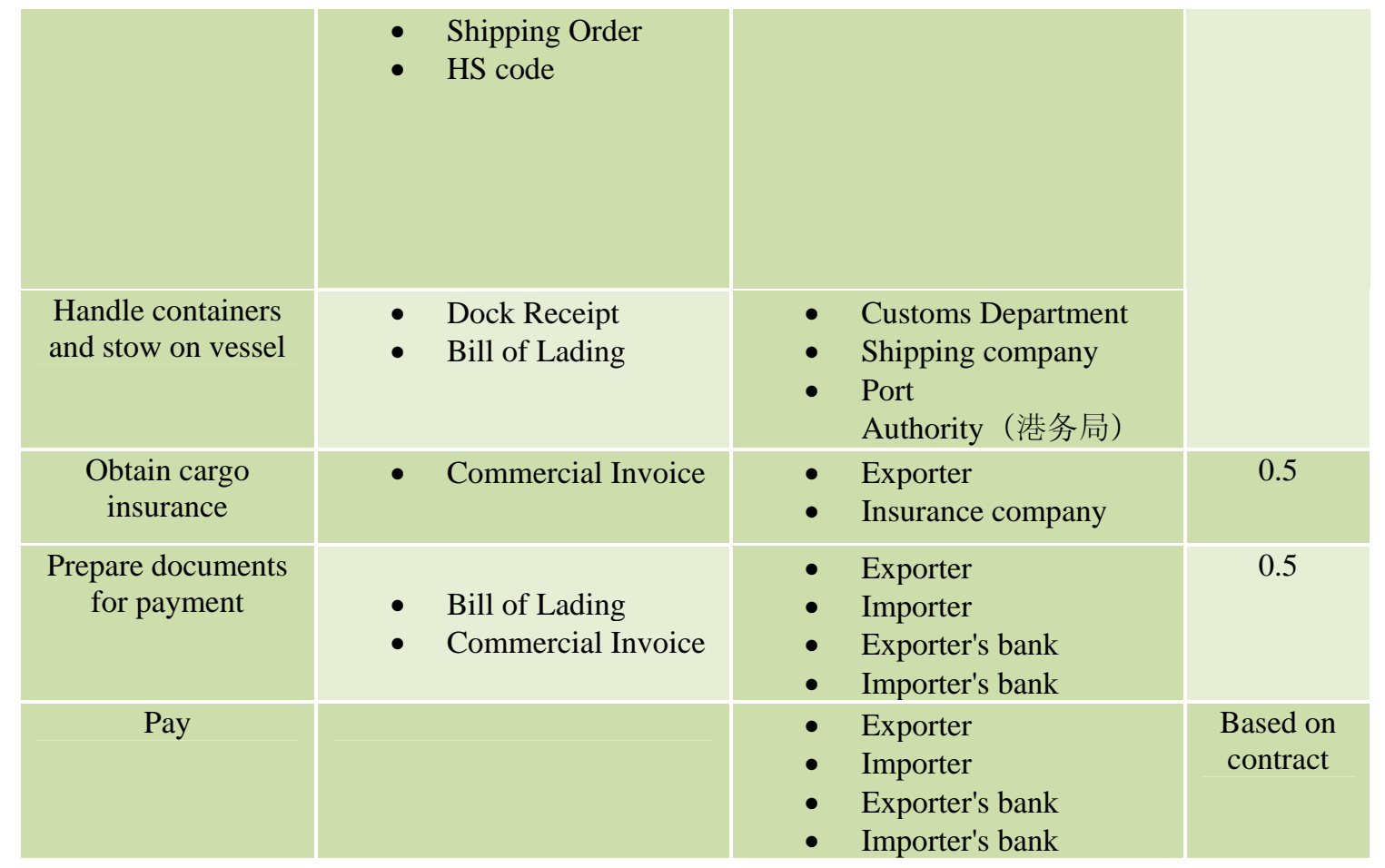

Figure 3: The Time-procedure Chart of Electronic Appliances from China

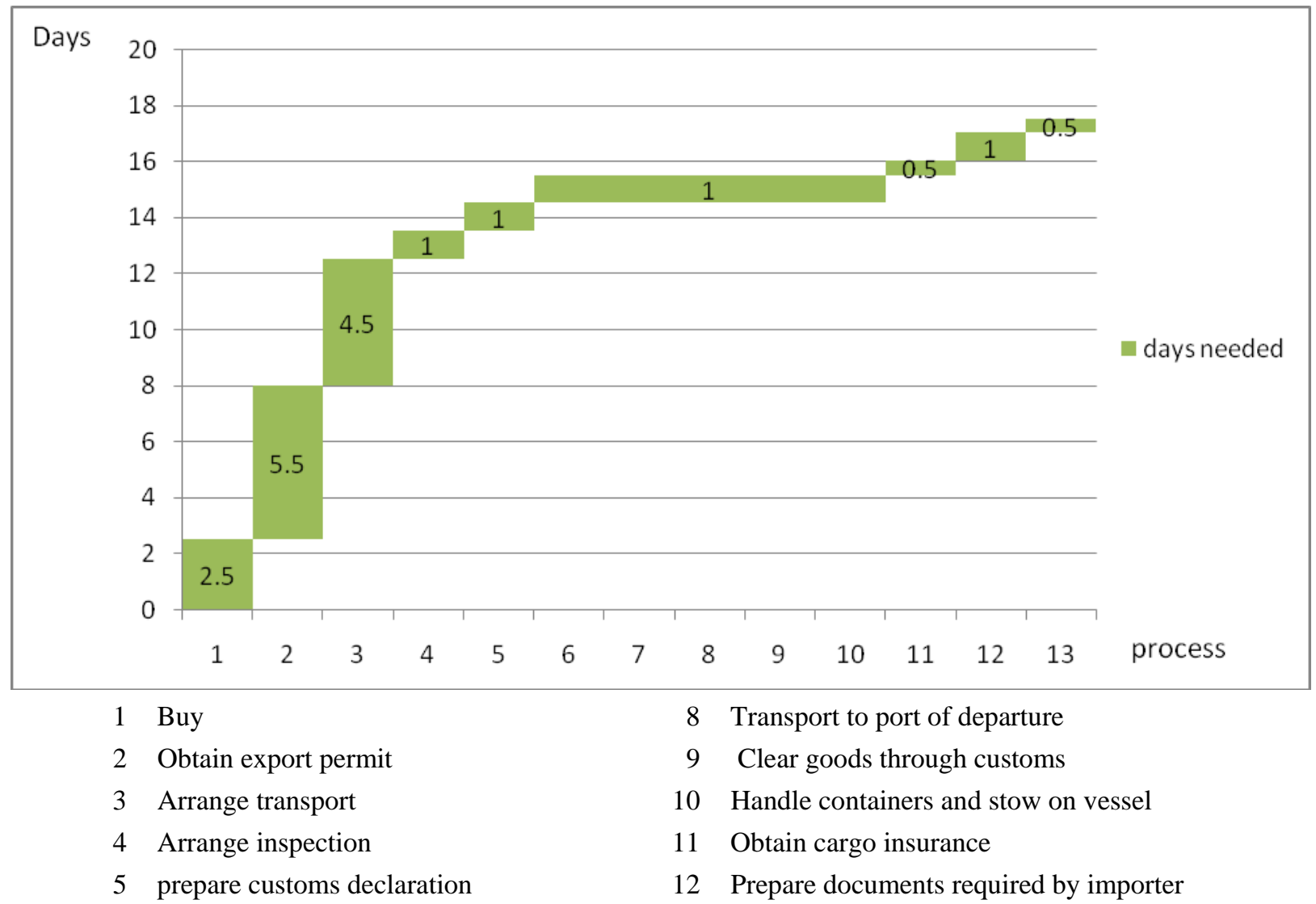


6 Collect empty containers from yard

13 prepare documents for payment

7 Stuff a container

1. Buy - The process of finalizing the order takes place within a day for both companies. Upon confirming the terms of the contract as well as the sample, a sales contract is drawn up. The Japanese seller will then get the goods ready for shipment.

2. Obtain import permit - Based on the information in the purchasing order and the OEM contract, the company fills an online application form for the Customs Department and the Committee of Foreign Trade and Economic Cooperation (CFTEC). The Customs Department will take 2-3 days to verify the information for an online approval. The online approval is printed for a verification stamp by CFTEC, which can be done in half a day. The stamped certificate is passed to the State Administration of Taxation for final stamping.

3. Documents preparation - The exporter will need to send 7 documents to importing company (Company $X$ and $P$ in our case). These include the Bill of Materials, Bill of Lading, the Purchase Order, the invoice, the packing list and a certificate of non-wood packing. These documents, plus the registry book (as explained earlier), a declaration of entrustment and an entrustment declaration for commodity inspection, are then handed over to the customs broker/freight forwarder. The preparation of these additional certificates will take the company 0.5 day.

4. Switching of Delivery Order - The customs broker switches the Bill of Lading with a Delivery Order issued by the shipping company. The shipping company charges about RMB200 per Bill of Lading. This is a quick process as no government agency is involved.

5. Inspection of Goods - The customs broker makes an application for customs clearance on behalf of the company. Inspection by the Commodity Inspection Bureau is random. If the goods are approved without inspection, the process can be done in half a day. If however, an inspection is required, the process can take between 1 - 5 days (the higher end for auto products). The fee charged for the inspection is $0.15 \%$ of the value stated in the invoice. However, Company $P$ reports that an import duty of $8-10 \%$ may be charged.

6. Clear goods through Customs - The inspection certificate together with the declaration of entrustment and the registry book are then forwarded to the Customs Department for customs clearance. The clearance can be done in 0.5 day.

7. Transport from dock to warehouse - The certificate of customs clearance, the delivery order and the packing list is required for the transportation company to get the goods out of the port.

8. Pay - payment for the imported goods are paid according to the contract. Since both Company $X$ and $P$ have long term relationships with the Japanese source, payments can be made on a regular basis rather than per shipment. It should also be noted that if the consignment is based on an OEM contract, there is no payment that the company makes to the exporter. If there is a need to prepare documents for the payment procedures, both Company $P$ and $X$ spend about half a day for this repetitive process. 
The processes, actors and documents involved in the import of textiles and auto parts from Japan are shown in Tables 13 and 14 respectively. Figures 4 and 5 summarize the number of days each process takes. It takes an average of 9.25 and 12 for companies $\mathrm{X}$ and $\mathrm{P}$ respectively for the trade facilitation process (not including the waiting period for payment to be made). A total of 13 documents are required, and between USD 293 440 (RMB 2000-3000) is incurred (not including shipping cost).

Table 13. Importing Textile from Japan - Company X

\begin{tabular}{|c|c|c|c|}
\hline Major Steps & Documents & Actors & Days \\
\hline Buy & - $\quad$ Purchase Order & - Importer and Exporter & 1 \\
\hline $\begin{array}{l}\text { Obtain import } \\
\text { permit }\end{array}$ & $\begin{array}{ll}\text { - } & \text { Purchase Order } \\
\text { - } & \text { OEM Contract } \\
\text { - } & \text { Import Permit }\end{array}$ & $\begin{array}{ll}- & \text { Importer } \\
\text { - } & \text { Customs Department } \\
& \text { Committee of Foreign Trade } \\
& \text { and Economic } \\
& \text { Cooperation(对外贸易经济合 } \\
& \text { 作局) } \\
\text { - } & \text { State Administration of } \\
& \text { Taxation（国家税务局） }\end{array}$ & 3.5 \\
\hline $\begin{array}{l}\text { Prepare } \\
\text { documents for } \\
\text { import }\end{array}$ & $\begin{array}{ll}\text { - } & \text { Bill of Material } \\
\text { - } & \text { OEM Contract } \\
\text { - } & \text { Commercial Invoice } \\
\text { - } & \text { Packing List } \\
\text { - } & \text { Bill of Lading } \\
\text { - } & \text { Export Register Book } \\
\text { - } & \text { Packing List } \\
\text { - } & \text { pertificate of non-wood } \\
& \text { entrustment } \\
\text { - } & \text { Commodity inspection of } \\
\text { - } & \text { Import Permitict }\end{array}$ & $\begin{array}{ll}\text { - } & \text { Import } \\
\text { - } & \text { Export } \\
& \text { Forwams Broker/Freight } \\
& \text { Forwarder (报关行/货代) }\end{array}$ & 1 \\
\hline $\begin{array}{c}\text { Switch for } \\
\text { Delivery Order }\end{array}$ & $\begin{array}{ll}\text { - } & \text { Bill of Lading } \\
\text { - } & \text { Delivery Order }\end{array}$ & $\begin{array}{ll}\text { - } & \text { Shipping Company } \\
\text { - } & \text { Customs Broker/Freight } \\
& \text { Forwarder }\end{array}$ & 0.5 \\
\hline Inspect the goods & $\begin{array}{ll}\text { - } & \text { Commercial Invoice } \\
\text { - } & \text { Customs declaration } \\
\text { - } & \text { Export Register Book } \\
\text { - } & \text { Packing List } \\
\text { - } & \text { Certificate of non-wood } \\
\text { - } & \text { packing } \\
\text { - } & \text { entruration certificate of } \\
\text { - } & \text { Comtrustment } \\
\text { - } & \text { Delivery Order } \\
\end{array}$ & $\begin{array}{ll}\text { - } & \text { Importer } \\
\text { - } & \text { Customs Broker/Freight } \\
\text { - } & \text { Forwarder } \\
& \text { Commodity Inspection Bureau }\end{array}$ & 1.25 \\
\hline
\end{tabular}




\begin{tabular}{|c|c|c|c|}
\hline $\begin{array}{l}\text { Clear goods } \\
\text { through customs }\end{array}$ & $\begin{array}{ll}\text { - } & \text { Customs declaration } \\
\text { - } & \text { Declaration certificate of } \\
\text { entrustment } \\
\text { - } & \text { Export Register Book } \\
\text { - } & \text { Certificate of Inspection }\end{array}$ & $\begin{array}{ll}\text { - } & \text { Importer } \\
\text { - } & \text { Customs Broker/Freight } \\
\text { - Forwarder Company } \\
\text { - Customs Department }\end{array}$ & 0.5 \\
\hline $\begin{array}{l}\text { Transport from } \\
\text { dock to } \\
\text { warehouse }\end{array}$ & $\begin{array}{ll}\text { - } & \text { Delivery Order } \\
\text { - } & \text { Packing List } \\
\text { - } & \text { Customs declaration }\end{array}$ & $\begin{array}{ll}\text { - } & \text { Shipping Company } \\
\text { - } & \text { Transportation company } \\
\text { - } & \text { Customs Broker/Freight } \\
& \text { Forwarder }\end{array}$ & 1 \\
\hline $\begin{array}{c}\text { Preparation of } \\
\text { Payment }\end{array}$ & $\begin{array}{ll}\text { - } & \text { Commercial Invoice } \\
\text { - } & \text { L/C } \\
\text { - } & \text { OEM Contract }\end{array}$ & $\begin{array}{ll}\text { - } & \text { Importer } \\
\text { - } & \text { Exporter } \\
\text { - } & \text { Importer's Bank } \\
\text { - } & \text { Exporter's Bank }\end{array}$ & 0.5 \\
\hline
\end{tabular}

Figure 4: The Time-procedure Chart of Textile Import from Japan

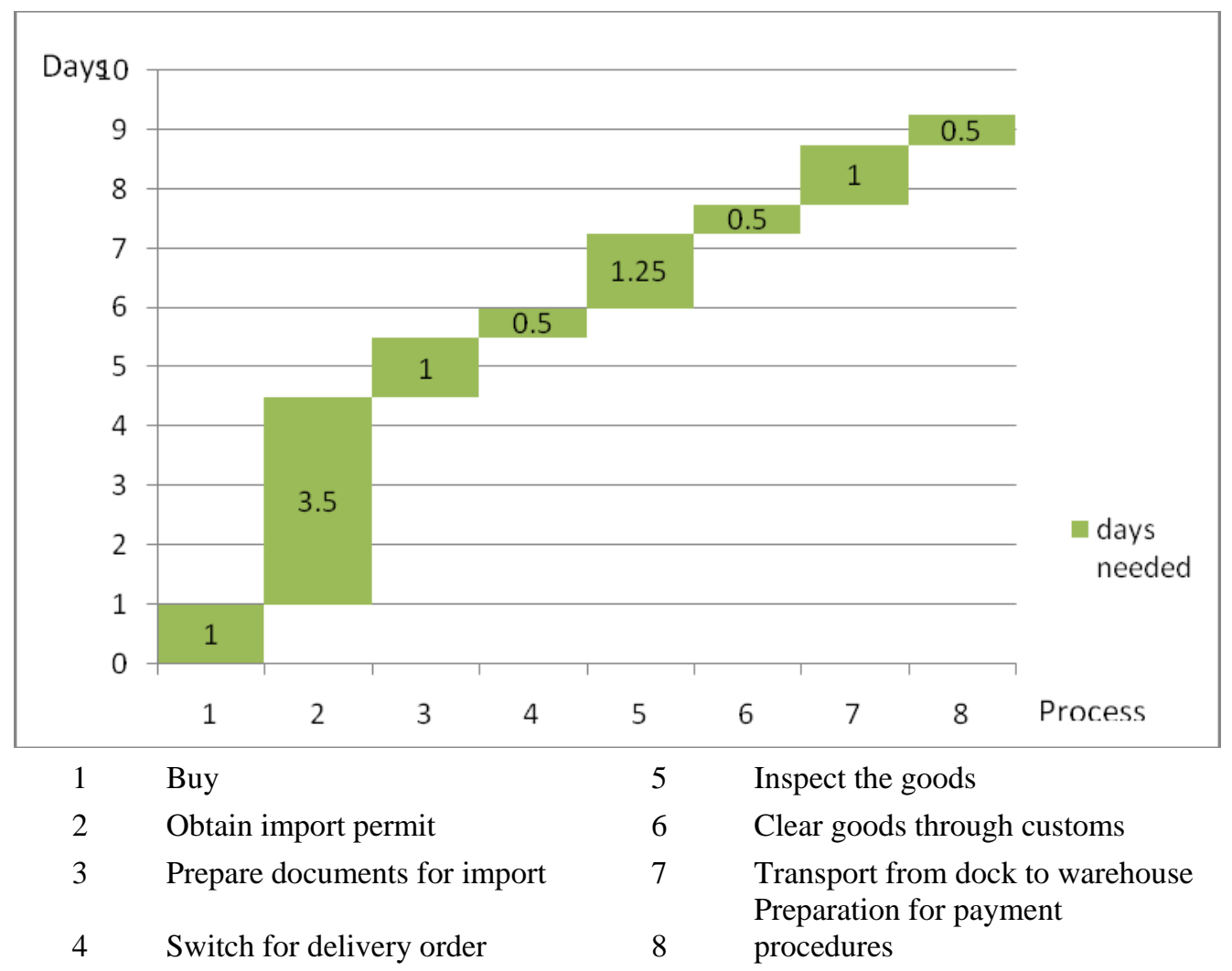


Figure 5: The Time-procedure Chart of Auto Parts from Japan

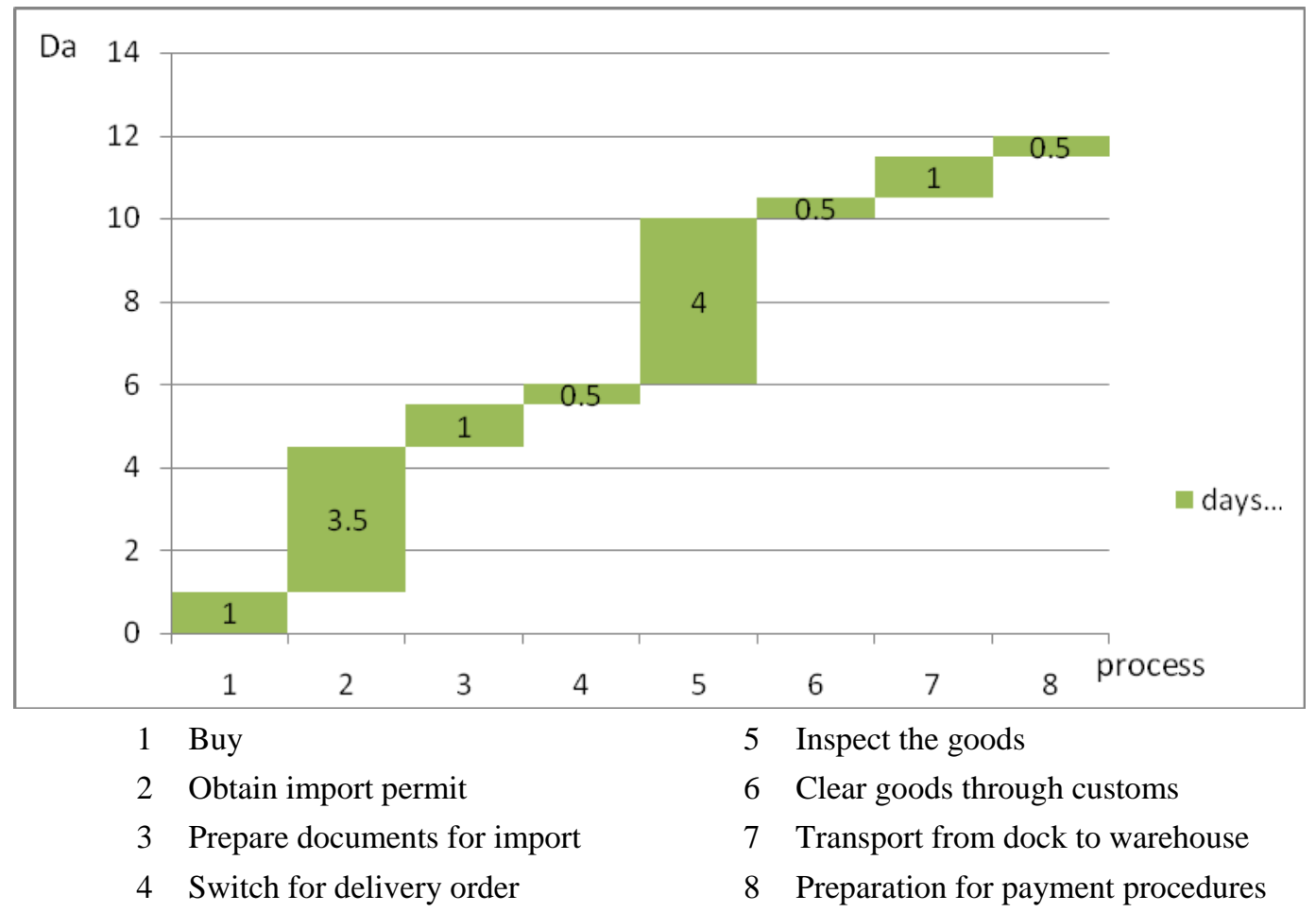

Table 14. Importing Auto parts from Japan - Company $P$

\begin{tabular}{|c|c|c|c|}
\hline Major Steps & Documents & Actors & Days \\
\hline Buy & - $\quad$ Purchase Order & - Importer and Exporter & 1 \\
\hline $\begin{array}{l}\text { Obtain import } \\
\text { permit }\end{array}$ & $\begin{array}{ll}\text { - } & \text { Purchase Order } \\
\text { - } & \text { OEM Contract } \\
\text { Import Permit }\end{array}$ & $\begin{array}{ll}\text { - } & \text { Importer } \\
\text { - } & \text { Customs Department } \\
\text { Economic } \\
\text { Cooperation(对外贸易经济合作 } \\
\text { 局) } \\
\text { - State Administration of } \\
\text { Taxation（国家税务局） }\end{array}$ & 3.5 \\
\hline $\begin{array}{l}\text { Prepare } \\
\text { documents for } \\
\text { import }\end{array}$ & $\begin{array}{ll}\text { - } & \text { Bill of Material } \\
\text { - } & \text { OEM Contract } \\
\text { - } & \text { Purchase Order } \\
& \text { Invomerce } \\
\text { - } & \text { Packing List } \\
\text { - } & \text { Bill of Lading } \\
\text { - } & \text { Export Register } \\
& \text { Book } \\
\text { - } & \text { Packing List } \\
\text { - } & \text { Certificate of } \\
& \text { non-wood } \\
& \text { packing }\end{array}$ & $\begin{array}{ll}\text { - } & \text { Importer } \\
\text { - } & \text { Exporter } \\
& \text { Forwams Broker/Freight } \\
& \text { Forwarder (报关行/货代) }\end{array}$ & 1 \\
\hline
\end{tabular}




\begin{tabular}{|c|c|c|c|}
\hline & $\begin{array}{ll}\text { - } & \text { Declaration } \\
\text { certificate of } \\
\text { entrustment } \\
\text { - } \quad \text { Commodity } \\
\text { inspection of } \\
\text { entrustment } \\
\text { - Import Permit }\end{array}$ & & \\
\hline $\begin{array}{c}\text { Switch for } \\
\text { Delivery Order }\end{array}$ & $\begin{array}{l}\text { - } \quad \text { Bill of Lading } \\
\text { - } \quad \text { Delivery Order }\end{array}$ & $\begin{array}{ll}\text { - } & \text { Shipping Company } \\
\text { - } & \text { Customs Broker/Freight Forwarder }\end{array}$ & 0.5 \\
\hline $\begin{array}{l}\text { Inspect the } \\
\text { goods }\end{array}$ & $\begin{array}{ll}\text { - } & \text { Commercial } \\
\text { - } & \text { Invoice } \\
& \text { Customs } \\
\text { - } & \text { declaration } \\
& \text { Export Register } \\
\text { - } & \text { Pook } \\
\text { - } & \text { Backing List of Lading } \\
\text { - } & \text { Certificate of } \\
& \text { non-wood } \\
\text { - } & \text { packing } \\
& \text { Declaration } \\
& \text { certificate of } \\
\text { entrustment } & \text { Entrustment for } \\
\text { - } & \text { Commodity } \\
\text { inspection } & \text { Delivery Order }\end{array}$ & $\begin{array}{ll}\text { - } & \text { Importer } \\
\text { - } & \text { Commodity Inspection Bureau } \\
\text { - } & \text { Customs Broker/Freight Forwarder } \\
& \text { Company } \\
\text { - } & \text { Customs Department }\end{array}$ & 4 \\
\hline $\begin{array}{l}\text { Clear goods } \\
\text { through } \\
\text { customs }\end{array}$ & $\begin{array}{ll}\text { - } & \text { Customs } \\
\text { declaration } \\
\text { - } & \text { Declaration } \\
\text { certificate of } \\
\text { entrustment } \\
\text { - } & \text { Export Register } \\
\text { Book } \\
\text { - Certificate of } \\
\text { Inspection }\end{array}$ & $\begin{array}{ll}\text { - } & \text { Importer } \\
\text { - } & \text { Customs Broker/Freight Forwarder } \\
\text { - Company } \\
\text { - Customs Department }\end{array}$ & 0.5 \\
\hline $\begin{array}{c}\text { Transport from } \\
\text { dock to } \\
\text { warehouse }\end{array}$ & $\begin{array}{ll}\text { - } & \text { Delivery Order } \\
\text { - } & \text { Packing List } \\
\text { - } & \text { Customs } \\
\text { declaration }\end{array}$ & $\begin{array}{ll}\text { - } & \text { Shipping Company } \\
\text { - } & \text { Transportation company } \\
\text { - } & \text { Customs Broker/Freight Forwarder }\end{array}$ & 1 \\
\hline $\begin{array}{l}\text { Preparation of } \\
\text { Payment }\end{array}$ & $\begin{array}{ll}\text { - } & \text { Commercial } \\
\text { Invoice } \\
\text { - } \quad \text { L/C } \\
\text { - } & \text { OEM Contract }\end{array}$ & $\begin{array}{ll}\text { - } & \text { Importer } \\
\text { - } & \text { Exporter } \\
\text { - } & \text { Importer's Bank } \\
\text { - } & \text { Exporter's Bank }\end{array}$ & 0.5 \\
\hline
\end{tabular}




\section{Observation and Discussion}

Detailed analysis of the processes involved in the imports and exports of the above mentioned goods using the BPA method allowed us to measure the length of time, costs (to a certain extent) and number of documents required.

A comparison of our results and those found by the World Bank (WB) study is shown in Table 15. There are some clear variance between our findings and those of the WB. The number of days required for getting the goods from the warehouse on to the ship (exports) and the reverse (imports) are markedly lower than the WB study. Our respondents claim that the process takes between 9 to 14 days. However, the number of documents involved in the process is much higher than the WB study. Company $\mathrm{M}$ for instance claims that there are 17 documents involved in the export process (compared to only 7 reported in the WB study). The costs involved averages about USD370.

Table 15. Days, Cost and Documents

\section{a. Import}

\section{Import}

\begin{tabular}{|c|c|c|c|}
\hline & WBDB2010 & $\begin{array}{c}\text { Company } X \\
\text { (textile-fabric and } \\
\text { accessories) }\end{array}$ & $\begin{array}{l}\text { Company } P \\
\text { (auto parts) }\end{array}$ \\
\hline \multicolumn{4}{|l|}{ No. of days } \\
\hline Documents Preparation & 15 & 5.5 & 5.5 \\
\hline .. Obtain import permit & & 3.5 & 3.5 \\
\hline .. Prepare docs for imports & & 1 & 1 \\
\hline .. Switch delivery order & & 0.5 & 0.5 \\
\hline .. Preparation for payment & & 0.5 & 0.5 \\
\hline Customs Clearance & 4 & 1.75 & 4.5 \\
\hline .. Clear goods through customs & & 0.5 & 0.5 \\
\hline .. Commodity Inspection & & 1.25 & 4 \\
\hline Ports and terminal handling & 2 & n.a. & n.a. \\
\hline Inland transportation and handling & 3 & 1.5 & 1.5 \\
\hline .. Arrange for inland transportation & & 0.5 & 0.5 \\
\hline .. Inland transportation & & 1 & 1 \\
\hline Total No. of Days & 24 & 8.75 & 11.5 \\
\hline Costs (USD per container) & 545 & $366-440$ & $293-440$ \\
\hline No. of documents (Electronic) & 5 & 13(4) & 13(4) \\
\hline
\end{tabular}




\section{b. Export}

\begin{tabular}{|c|c|c|c|}
\hline & \multicolumn{3}{|c|}{ Export } \\
\hline & WBDB2010 & $\begin{array}{c}\text { Company X } \\
\text { (textile and } \\
\text { garments) }\end{array}$ & $\begin{array}{c}\text { Company M } \\
\text { (electronics } \\
\text { appliances) }\end{array}$ \\
\hline \multicolumn{4}{|l|}{ No. of days } \\
\hline Documents Preparation & 14 & 2.5 & 7 \\
\hline .. Obtain export permit & & n.a. & 5.5 \\
\hline .. Prepare docs for customs clearance & & 0.5 & 1 \\
\hline .. Prepare docs for importer & & 1 & 0.5 \\
\hline .. Preparation for payment & & 1 & n.a. \\
\hline Customs Clearance & 2 & 2.3 & 1.2 \\
\hline .. Clear goods through customs & & 0.3 & 0.2 \\
\hline .. Commodity Inspection & & 2 & 1 \\
\hline Ports and terminal handling & 2 & 0.3 & 0.2 \\
\hline .. Handle cargo and stowage & & 0.3 & 0.2 \\
\hline Inland transportation and handling & 3 & 5.4 & 5.6 \\
\hline .. Arrange for inland transportation & & 3 & 4.5 \\
\hline .. Obtain Cargo Insurance & & 1 & 0.5 \\
\hline ..Collect and stuff container & & 1 & 0.4 \\
\hline .. Inland transportation & & 0.4 & 0.2 \\
\hline Total No. of Days & 21 & 10.5 & 14 \\
\hline Costs (USD per container) & 500 & $293-440$ & $293-440$ \\
\hline No. of documents (Electronic) & 7 & $15(3)$ & $17(7)$ \\
\hline
\end{tabular}

The variation could be due to several reasons:

a. Our respondent companies have long term relationships with buyers/sellers. They have also been in the business for a long time. As such, they are familiar with the process and so may be able to clear the obstacles involved in the process in a shorter period of time. Furthermore, due to the nature of long term contracts, obtaining import/export permits for a contract rather than on a consignment basis is also likely.

b. The WB study might have only considered the number of documents handled by the freight forwarder. We have also included those documents that are handled by the buyer/seller. 
c. All our respondents use freight forwarders/customs brokers. These entities are able to speed up the process of customs clearance because of the close connections and/or experience they have with the government agencies. Connections or guanxi is an integral part of business and private-public relationship in China.

The use of freight forwarders and custom brokers is prevalent in China. Nearly all the companies that we approached (including those not included in this study) reported using these agencies. According to a customs broker, nearly 95\% of China's trade goes through forwarders and brokers. On the one hand, the use of these "go-betweens" helps to facilitate the process of inspection and customs clearance. The companies are able to "outsource" the obstacles of dealing with the various government agencies, and concentrate on what they do best i.e. produce. On the other hand, the activities carried out by these brokers remain to be a black box - a domain that is only known by the brokers and the customs officers. Obviously, the opportunities for corrupt practices abound. The companies interviewed for this project, particularly the smaller ones, were quite ignorant as to what exactly happens after documents are handed over to the customs broker. Nevertheless, the services provided by the broker are invaluable.

The role of the broker will continue as long as the inspection and customs clearance processes require the approval of the customs officer in charge. In China, these processes are still people-based rather than system based. Although there will be an increasing number of documents that would go electronic and marginally increase the speed of the process, at the end, the online document would have to be printed and signed/stamped. That face-to-face encounter could still result in corrupt practices.

In conclusion, the trade facilitation processes that exist in China seem comparatively efficient. The number of documents involved is large, but given information technology and the frequency of these procedures, this does not seem to be of concern to firms. However, the number of documents increases the probability of errors and so the rejection of an application. Reducing the number of documents could encourage firms to handle inspection and customs clearance on their own which may make the services of the broker redundant. Although previous studies (Wilson, 2007) showed that a $10 \%$ reduction in trade documents can increase trade by more than $11 \%$, in the case of China however, diminishing returns would surely apply. Thus, there is no guarantee that reducing the number of documents will speed up trade facilitation.

The findings and the conclusions of the paper are however subject to several limitations. First, our findings are based on a handful of case studies. It is premature to generalize these findings to reflect all import and export procedures in China. The types of importers and exporters vary based on size, ownership, trading partners etc. The challenges faced by these traders would differ from one to another. Second, the companies in our study use Shanghai and Shenzhen as their main ports. There are other major ports (e.g. Tianjin) in China whose procedures may be different. Third, our BPA analysis relies on the input provided by the staff and executives who are involved in the relevant trade procedures. It is likely that both the researchers and the executives might have overlooked some documents or costs involved in the process due to the repetitive 
nature of these procedures. Nevertheless, we hope that the findings contribute in a small way towards greater facilitation of trade among businesses in China. 


\section{References}

Erixon, F., Messerlin, P. and Sally, R. (undated), “China’s Trade Policy Post-WTO Accession: Focus on China-EU Relations, European Centre for International Political Economy, www.ecipe.org.

Engman, M. (2005), "The Economic Impact of Trade Facilitation", OECD Trade Policy Working Papers, No. 21, OECD Publishing. doi:10.1787/861403066656

Greene, M. and Tsai,G. (2008), "Enhancing market Openness Through Regulatory Reform in the People’s Republic of China”, OECD Trade Policy Working Paper No. 83.

Ianchovichina, E. and Martin, W. (2001), “Trade Liberalization in China’s Accession to the WTO”, Policy Research Working Paper No. 2623, World Bank, Washington DC.

Wilson, N. (2007), "Examining the Trade Effects of Certain Customs and Administrative Procedures”, OECD Trade Policy Working Paper No. 42, OECD, France.

Chen, Wenjing and Li, Wei (2006), “An Evaluation of the Need and Cost of Selected Trade facilitation Measures in China - Implications for the WTO Negotiations on Trade Facilitation”, ArtNet Working Paper Series No. 5, Bangkok.

Duval, Y. and Utoktham, C. (2009), "Behind-the-Border Trade Facilitation in Asia-Pacific: Cost of Trade, Credit Information, Contract Enforcement and Regulatory Coherence”, UNESCAP Trade and Investment Division, Staff Working Paper 02/09, UNESCAP, Bangkok.

OECD (2005), “The Cost and Benefits of Trade Facilitation”, OECD Policy Brief, OECD: France.

OECD (2003), "Trade Facilitation: The Benefits of Simpler, More Transparent Border Procedures”, OECD Policy Brief, OECD: France.

Ramasamy, B. (2009), “Free Trade Agreements and International Production Networks: China and the Automotive Industry”, ArtNet Research Project. 


\section{Appendix 1: The impact of trade facilitation on trade flow}

\begin{tabular}{|c|c|}
\hline Author(year) & Key findings \\
\hline APEC(2004a) & $\begin{array}{l}\text { Based on a gravity model exercise for APEC economies, the authors find that improved } \\
\text { trade facilitation by } 10 \text { percent boots intra-APEC imports by a minimum of } 0.5 \text { percent } \\
\text { in the area of customs procedures. }\end{array}$ \\
\hline $\begin{array}{l}\text { Dollar et } \\
\text { al.(2004) }\end{array}$ & $\begin{array}{l}\text { Based on survey results from 7,302 companies in eight developing economies } \\
\text { (including Brazil, China and India), the authors find that "costoms clearance times...are } \\
\text { key determinants of...export status." Maximum Likelihood estimates show that costoms } \\
\text { clearance times for both imports and exports have a significant negative effect on } \\
\text { exportation. }\end{array}$ \\
\hline Kim et al.(2004) & $\begin{array}{l}\text { Based on a gravity model exercise for APEC economies, the authors conclude that an } \\
\text { improvement in customs procedures performance by } 50 \text { percent would increase imports } \\
\text { by } 1.7-3.4 \text { percent in industrialised APEC economies, } 2.0-4.5 \text { percent in newly } \\
\text { industrialised APEC economies, and 7.7-13.5 percent in industrialising APEC } \\
\text { economies. }\end{array}$ \\
\hline $\begin{array}{l}\text { Wilson et } \\
\text { al.(2004) }\end{array}$ & $\begin{array}{l}\text { Based on a gravity model exercise for } 75 \text { countries, the authors find that improvements } \\
\text { in port efficiency and customs administration for below-average efficient countries } \\
\text { half-way up to the global average would increase trade flows by USD } 107 \text { billion and } \\
\text { USD } 33 \text { billion respectively. Improvements in customs administration would benefit all } \\
\text { regions but in particular develop country importers. Port efficiency improvement would } \\
\text { also greatly benefit developing countries. }\end{array}$ \\
\hline $\begin{array}{l}\text { Batra et } \\
\text { al.(2003) }\end{array}$ & $\begin{array}{l}\text { Based on survey results from } 8,560 \text { companies in some } 80 \text { countries, 'customs/foreign } \\
\text { trade regulations' were identified as the second most serious " tax and regulatory } \\
\text { constraint" on operations and business growth/trade in Latin America, Africa, } \\
\text { Developing East Asia and the Middle East. In } 44 \text { percent of non-OECD countries, half } \\
\text { or more of the companies reported that 'customs/foreign trade regulations' were } \\
\text { moderate or major obstacles to operations and business growth/trade. SMEs were } \\
\text { particularly affected. }\end{array}$ \\
\hline Fox et al.(2003) & $\begin{array}{l}\text { Based on GTAP-model estimates, the authors conclude that a removal of the frictions in } \\
\text { border crossing (delays) between Mexico and the United States would lead to a USD } 7 \\
\text { billion rise in trade, with southbound trade estimated to increase by USD } 6 \text { billion and } \\
\text { northbound trade by USD } 1 \text { billion. Welfare would increase by USD } 1.8 \text { billion in } \\
\text { Mexico and by USD } 1.4 \text { billion in the United States. }\end{array}$ \\
\hline $\begin{array}{l}\text { Wilson et } \\
\text { al.(2003) }\end{array}$ & $\begin{array}{l}\text { Based on a gravity model exercise for APEC economies, the authors find that enhanced } \\
\text { port efficiency has a large and positive effect on trade. Improvements in customs } \\
\text { significantly expand trade but to a lesser degree than the effects of ports improvements. } \\
\text { If port efficiency and custom environment in below-APEC-average members were } \\
\text { brought half-way to the initial APEC-average, intra-APEC trade is estimated to } \\
\text { increase by } 11.5 \text { percent. A } 9.7 \text { percent gain (USD } 117 \text { billion) is expected from } \\
\text { increased port efficiency and } 1.8 \text { percent (USD } 22 \text { billion) from an improved customs } \\
\text { environment. }\end{array}$ \\
\hline
\end{tabular}




\begin{tabular}{|l|l|}
\hline $\begin{array}{l}\text { Hummels } \\
\text { (2001) }\end{array}$ & $\begin{array}{l}\text { The author estimated that each additional day spent in transportation reduces the } \\
\text { probability that the US will source from the country by 1-1.5 percent for manufactured } \\
\text { goods while no effect is found for commodities. Each day saved in shipping time is } \\
\text { worth } 0.8 \text { percent advalorem for manufactured goods. }\end{array}$ \\
\hline APEC (1999) & $\begin{array}{l}\text { Based on CGE analysis, the authors find that a 1 percent reduction in import prices } \\
\text { from reduced TTCs) for the industrial and newly industrialising countries of Korea, } \\
\text { Chinese Taipei and Singapore, and a } 2 \text { percent reduction for the other developing } \\
\text { countries yield an increase in APEC merchandise trade of 3.3 percent. }\end{array}$ \\
\hline
\end{tabular}

Source: Engman (2005) 
Appendices: BPA Charts 


\section{Appendix 2}

Business Processes of Garments Export from China 


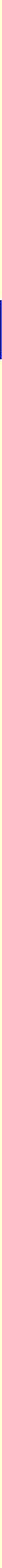




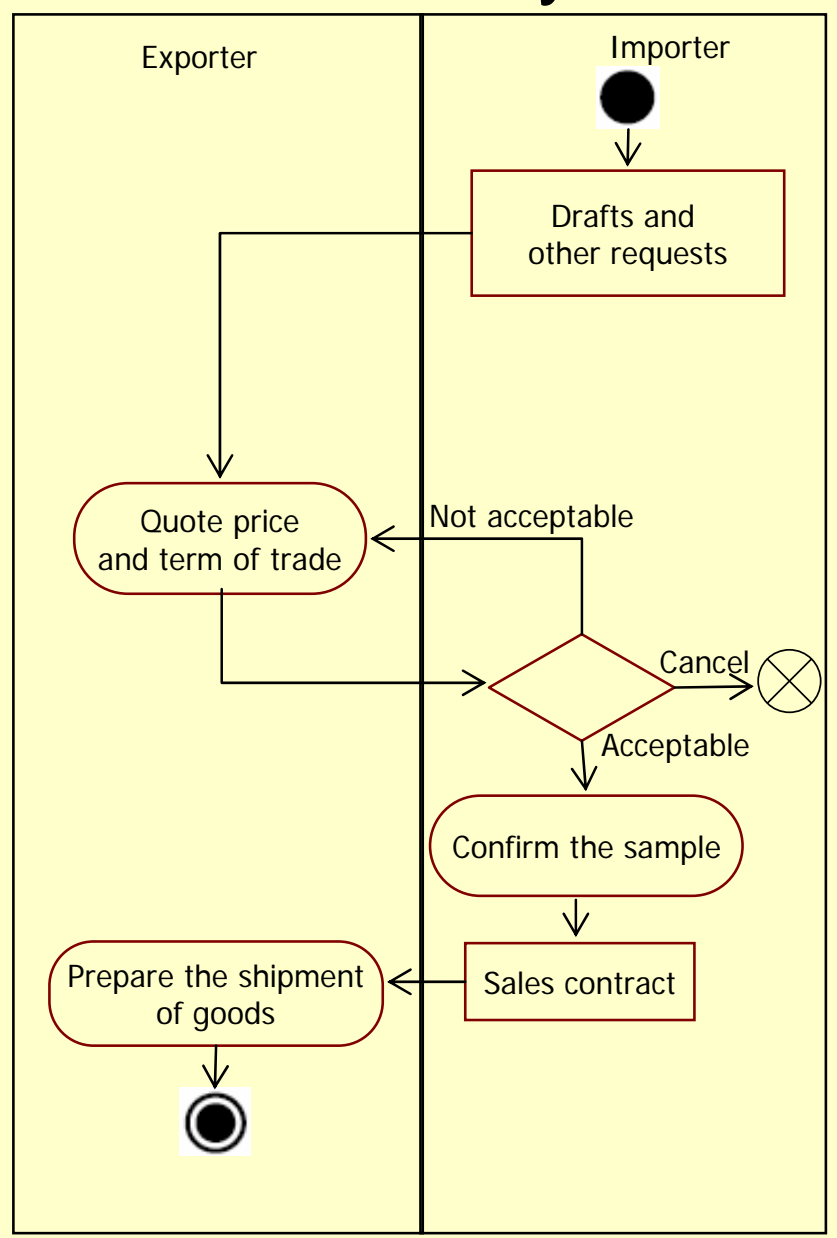


2.1 Arrange transport

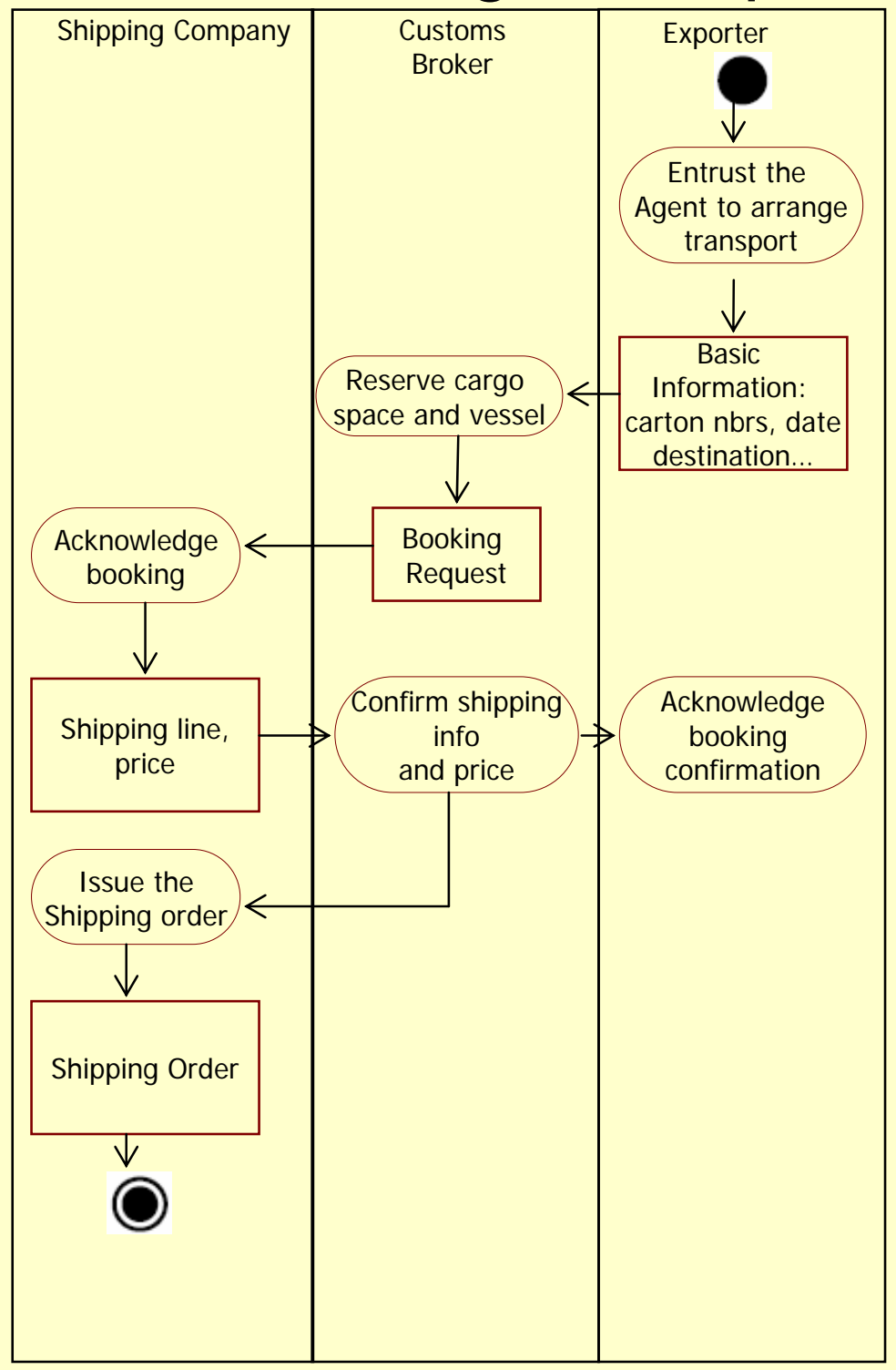


2.2 Arrange the inspection

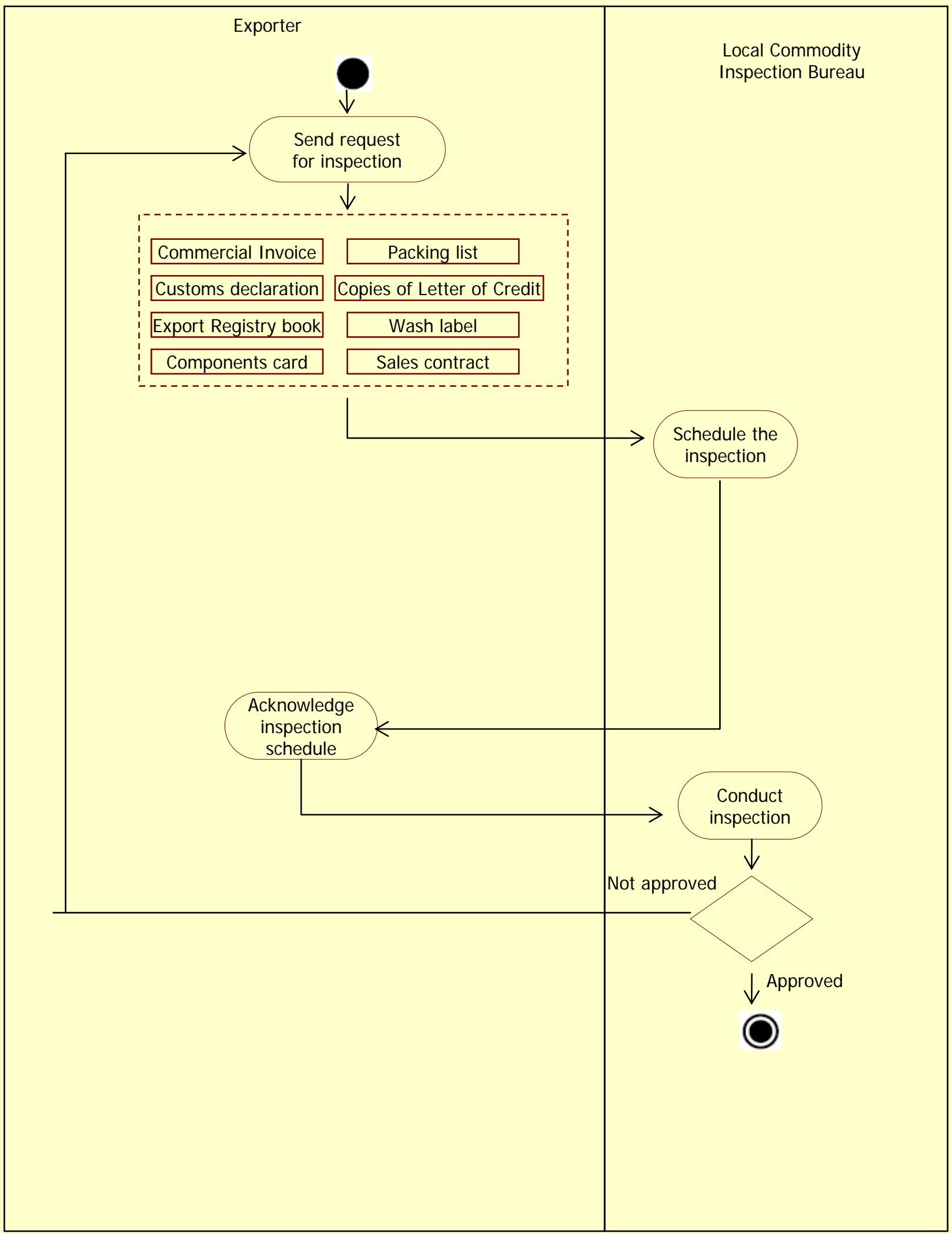


2.3 Obtain cargo insurance

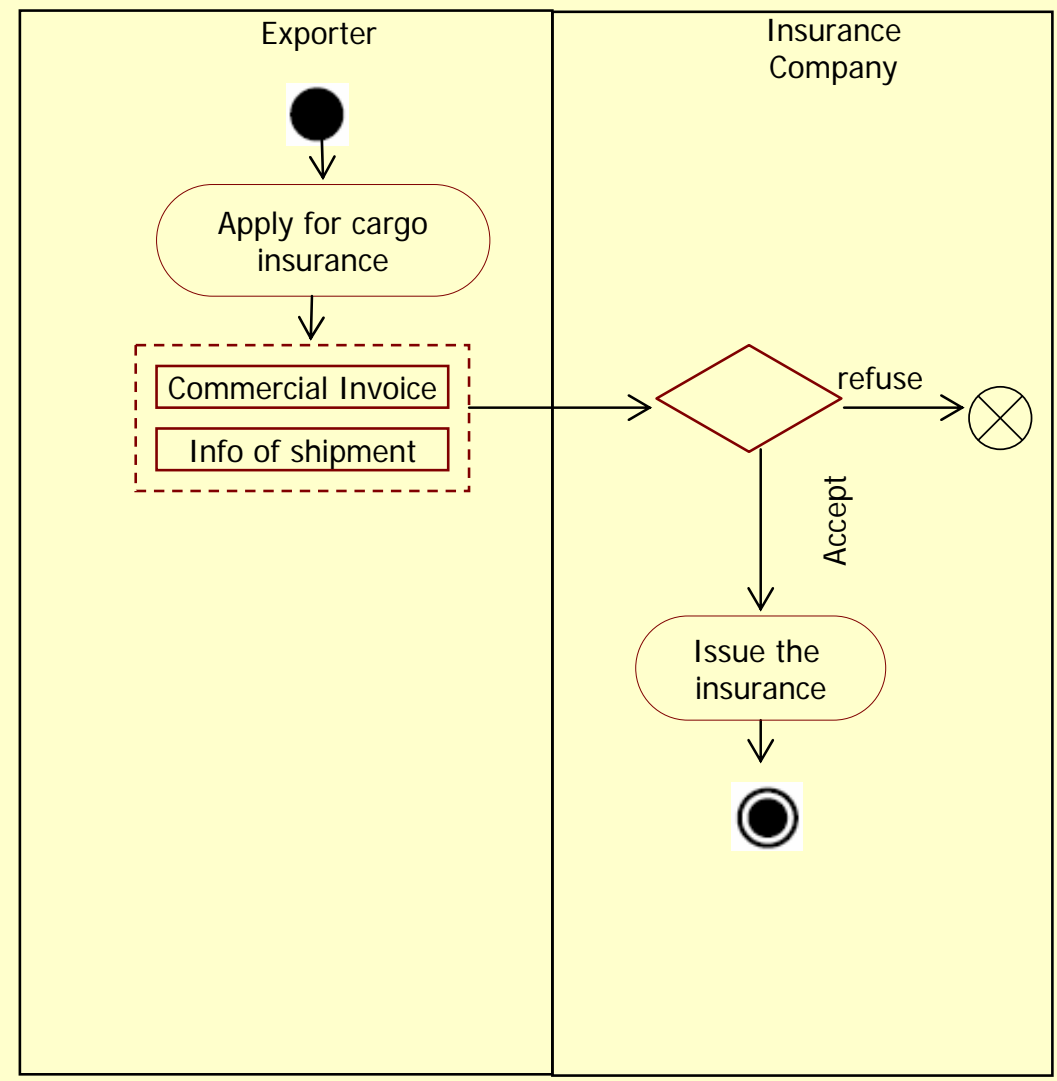


2.4 Collect empty container(s) from yard

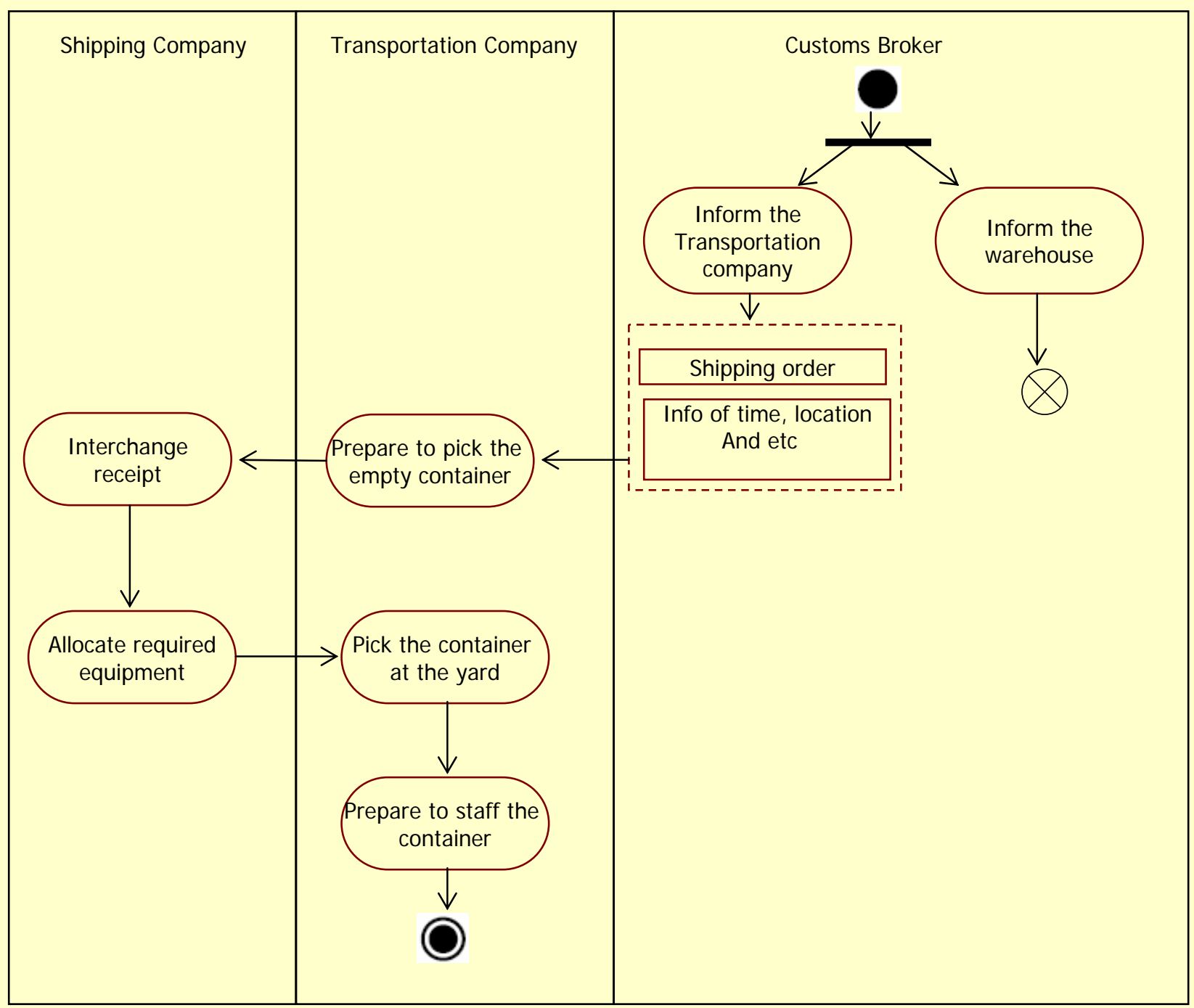




\subsection{Stuff a container}

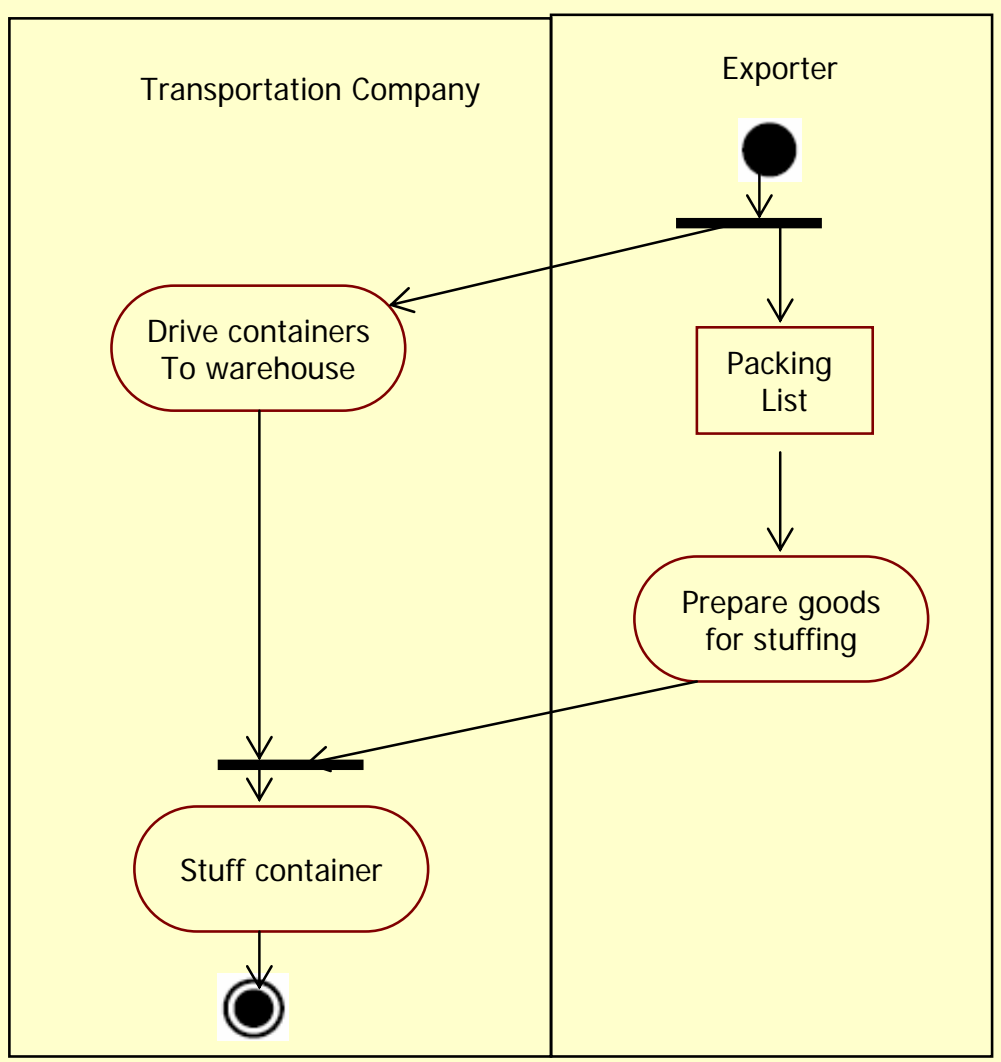


2.6 Iransport to Port of Departure

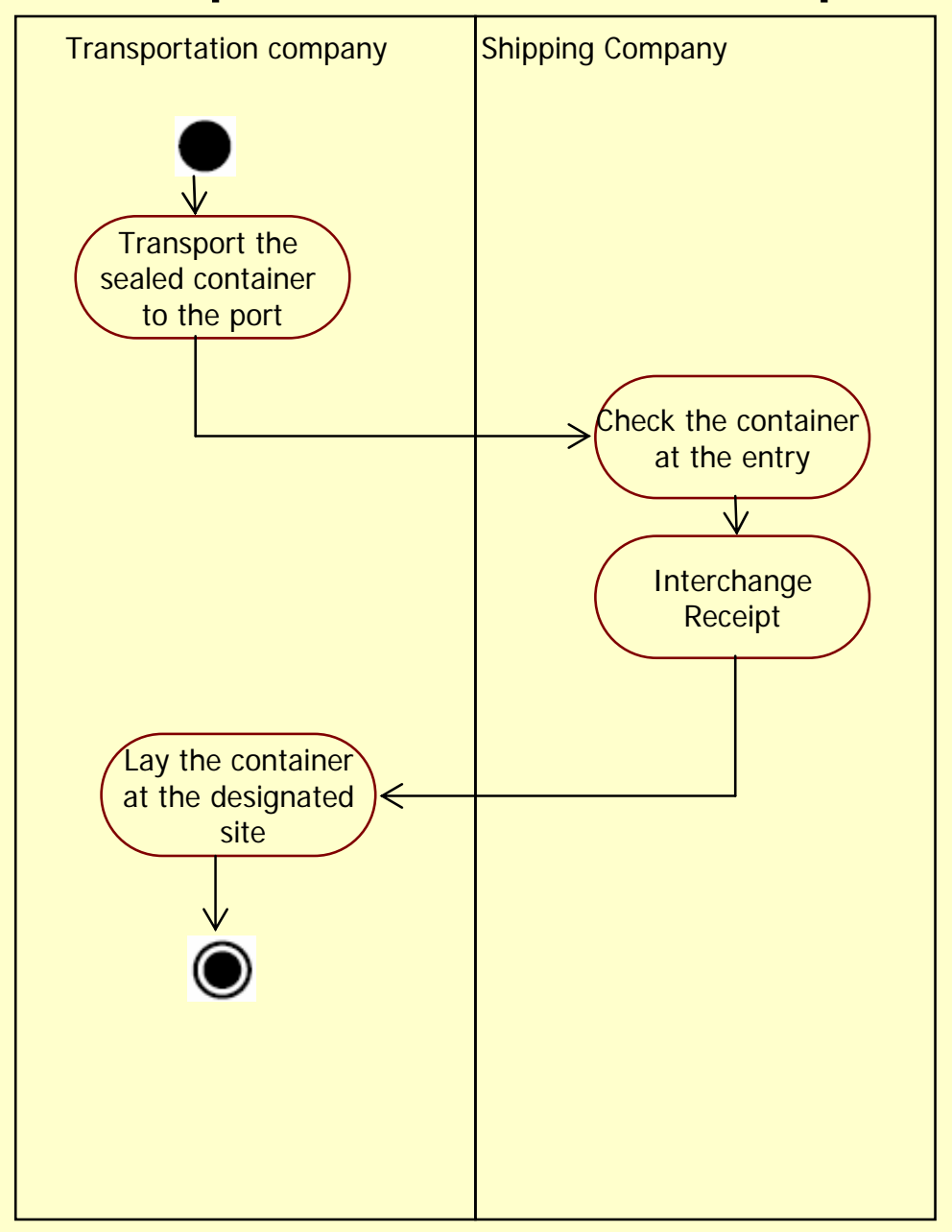


2.1 Clear goods through customs

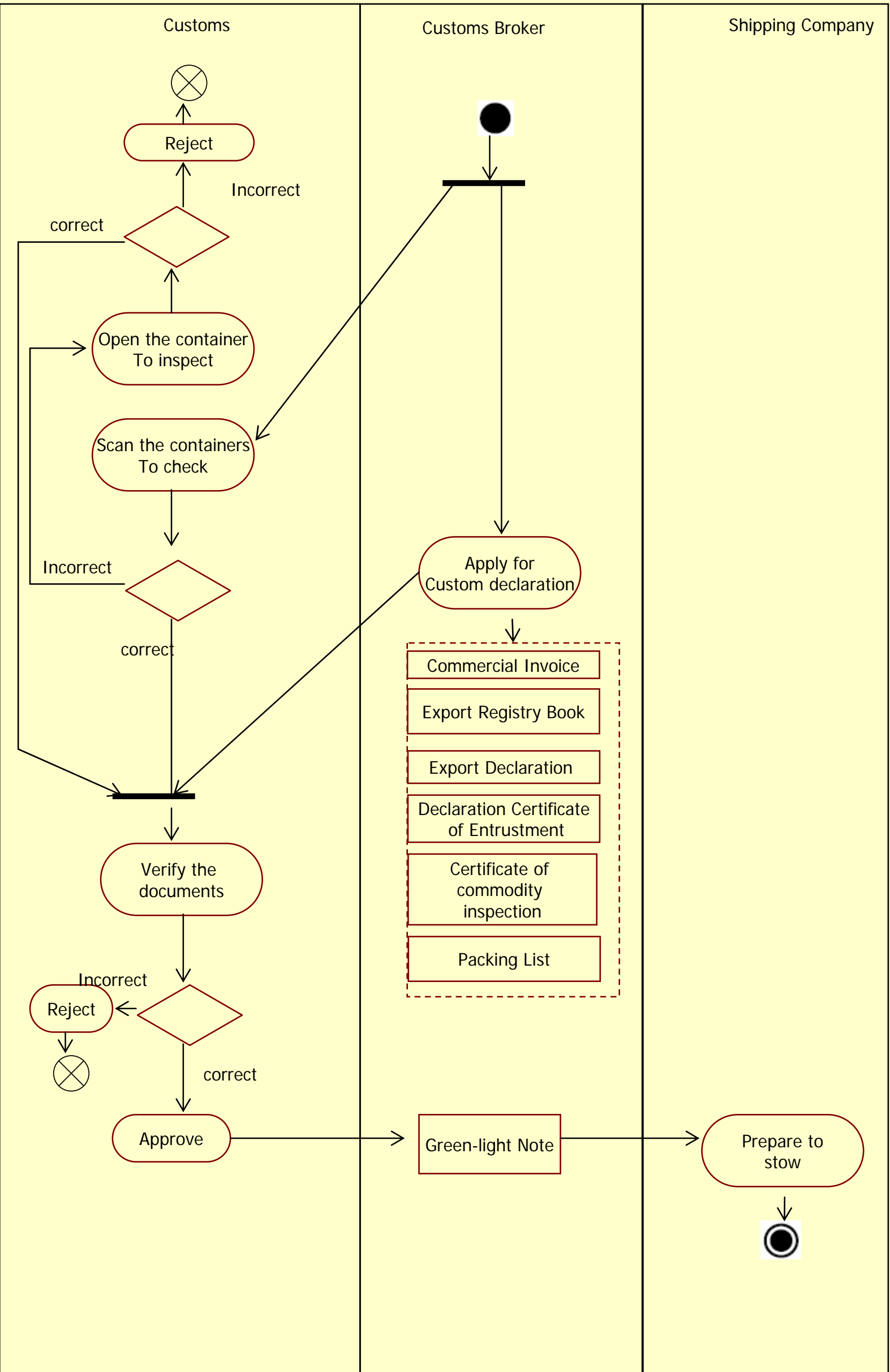


2.8 Handle container and stow on vessel

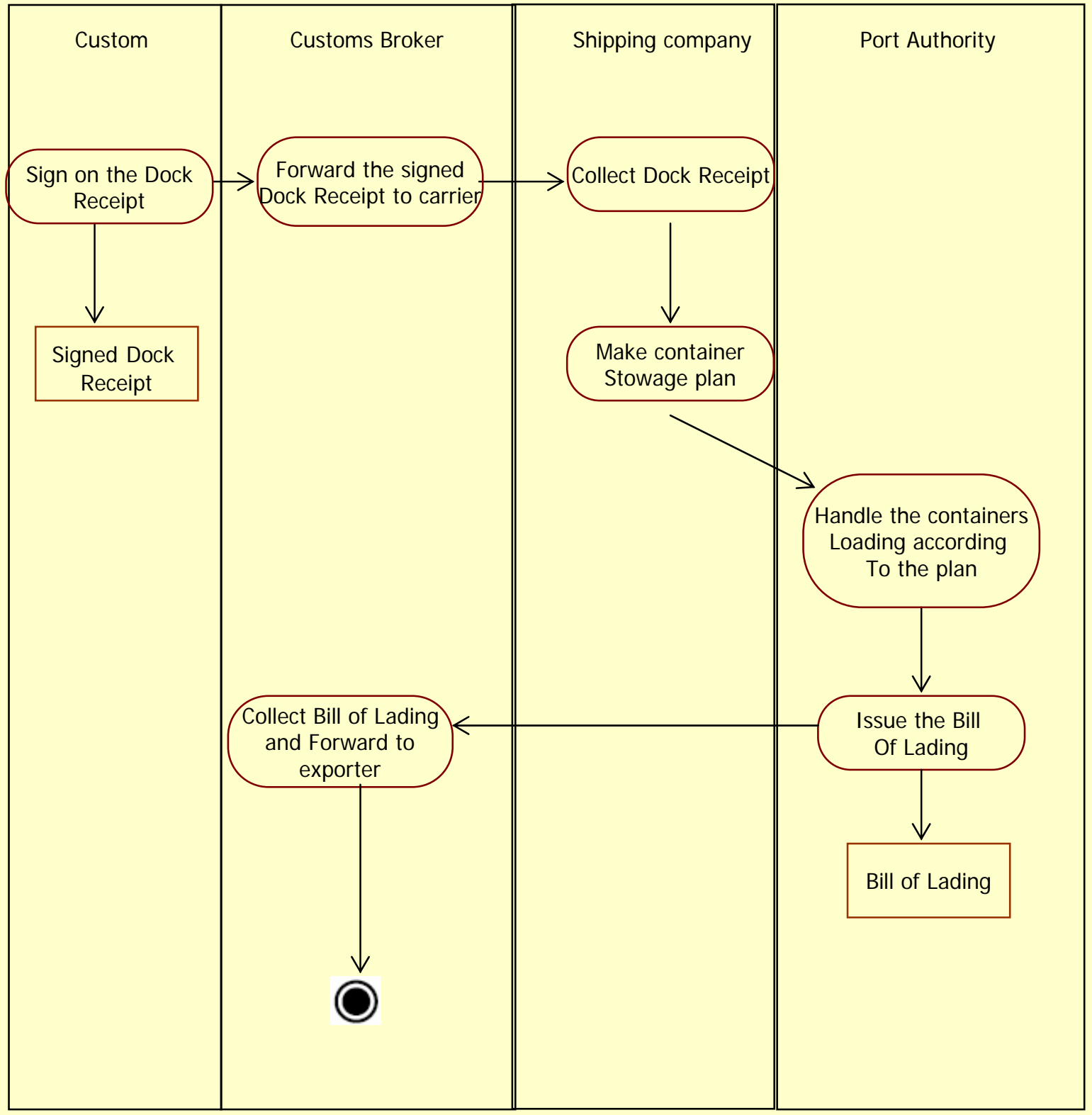

11 


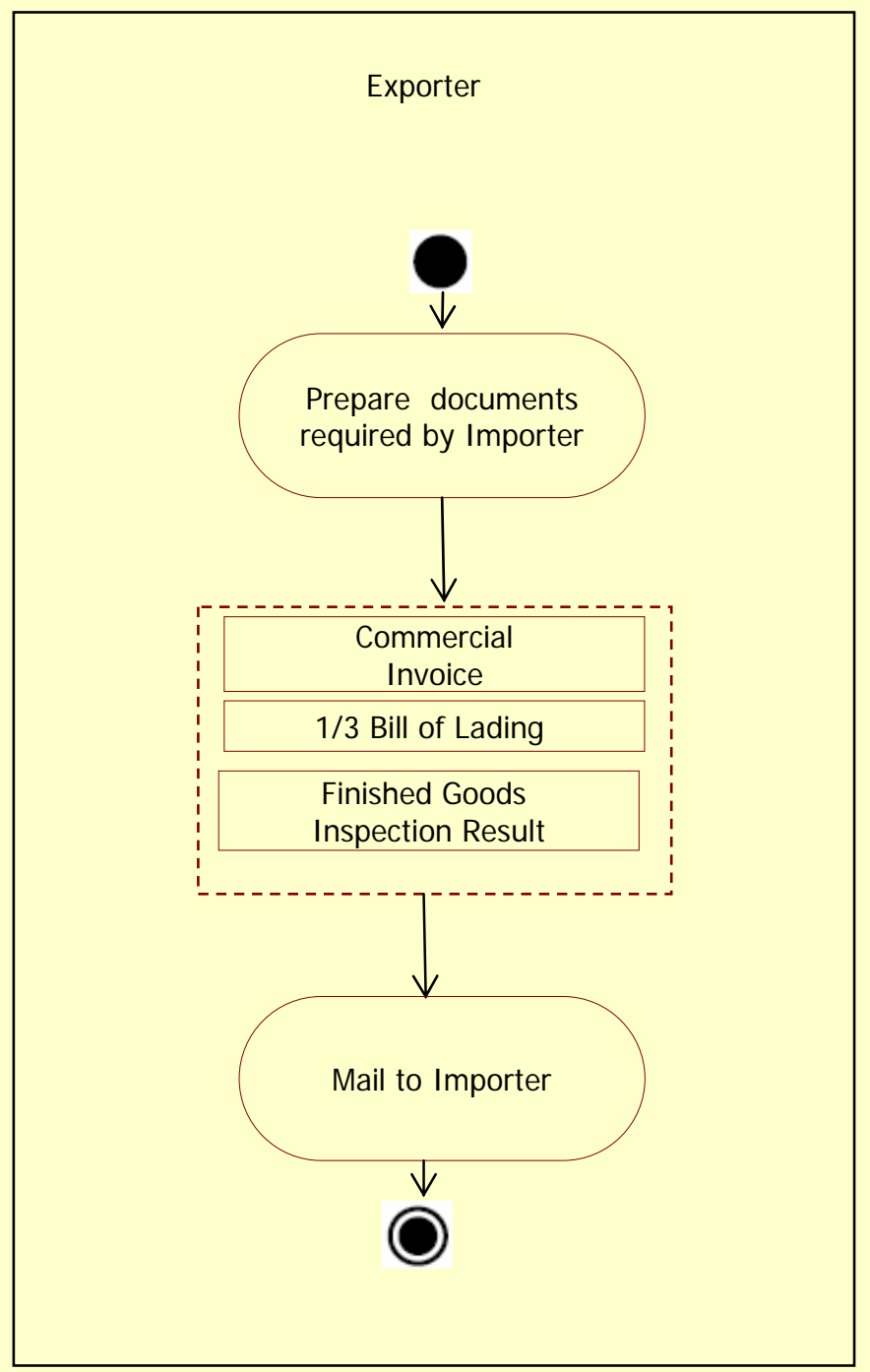




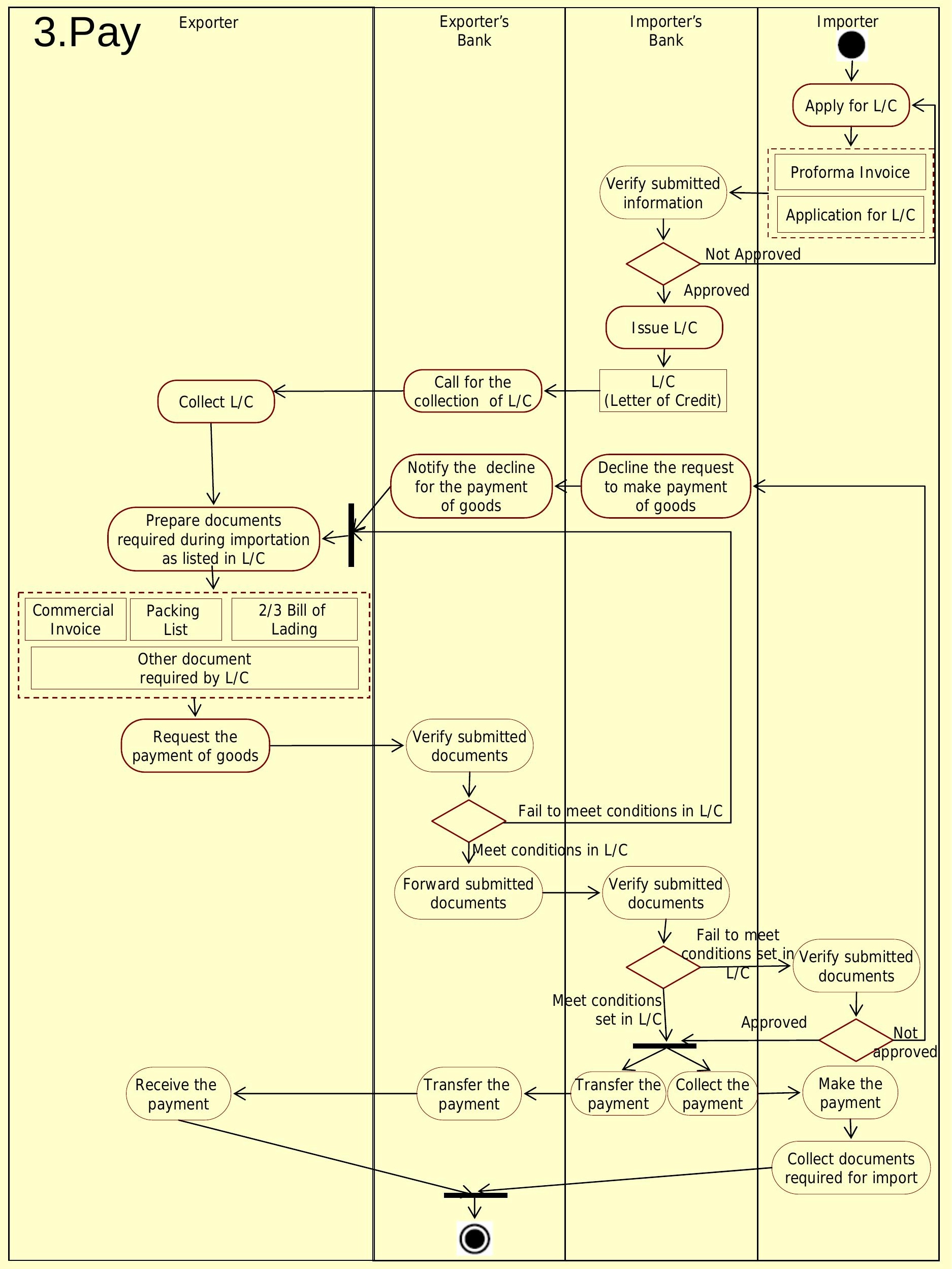




\section{Appendix 3}

Business Processes of

Electronic Appliances

Export from China 


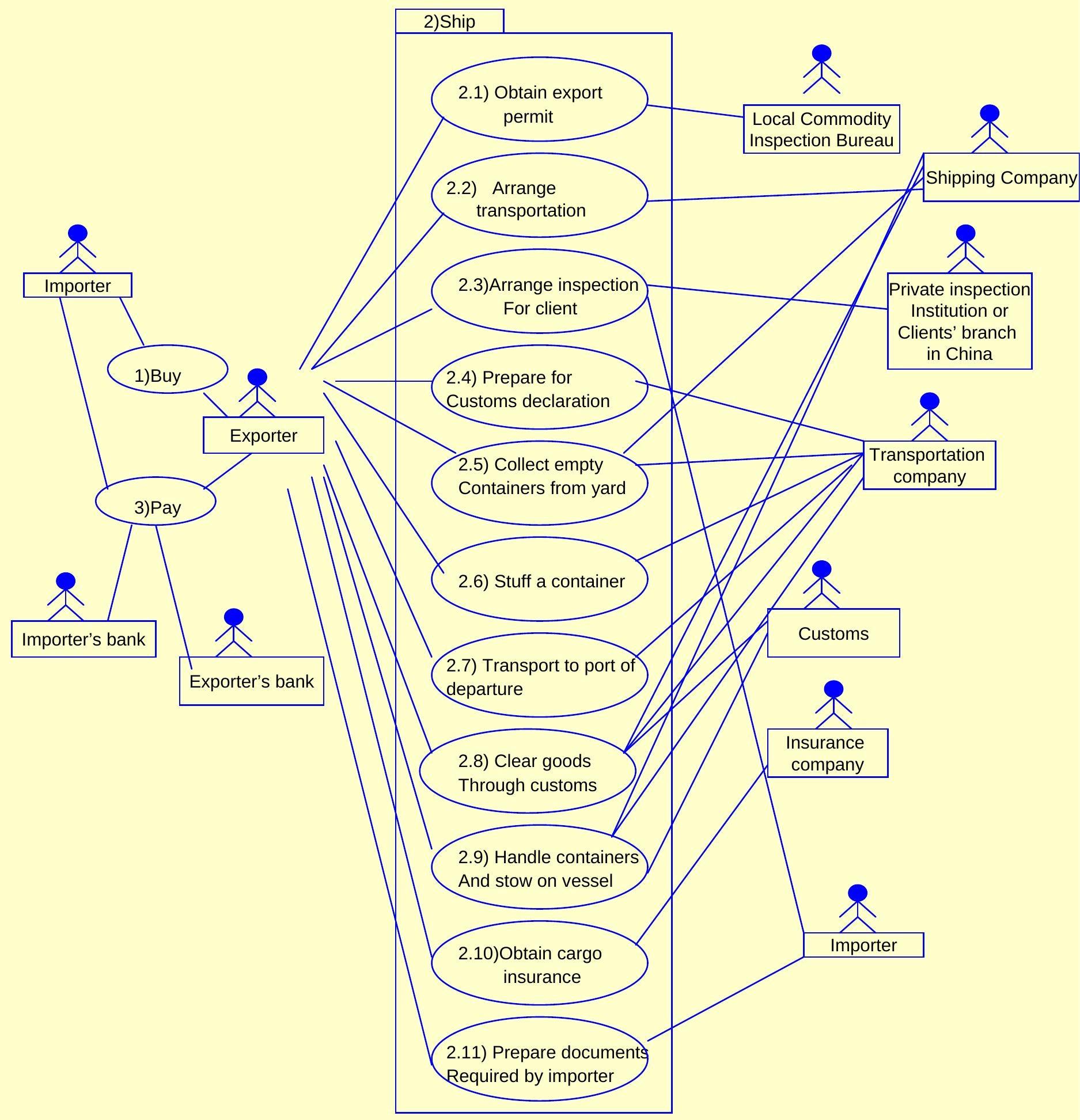


1.Buy

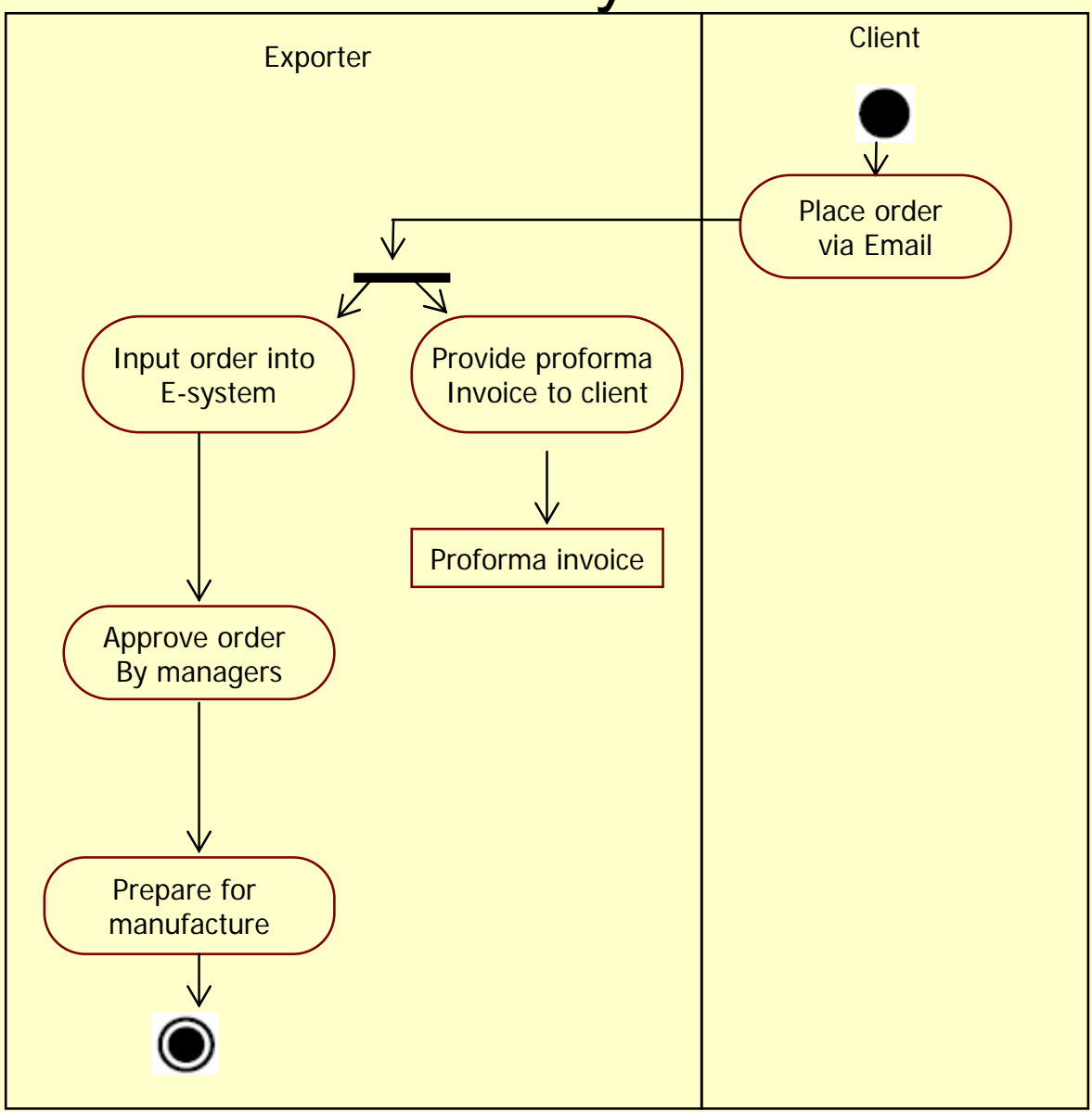


2.1 Obtain export permit

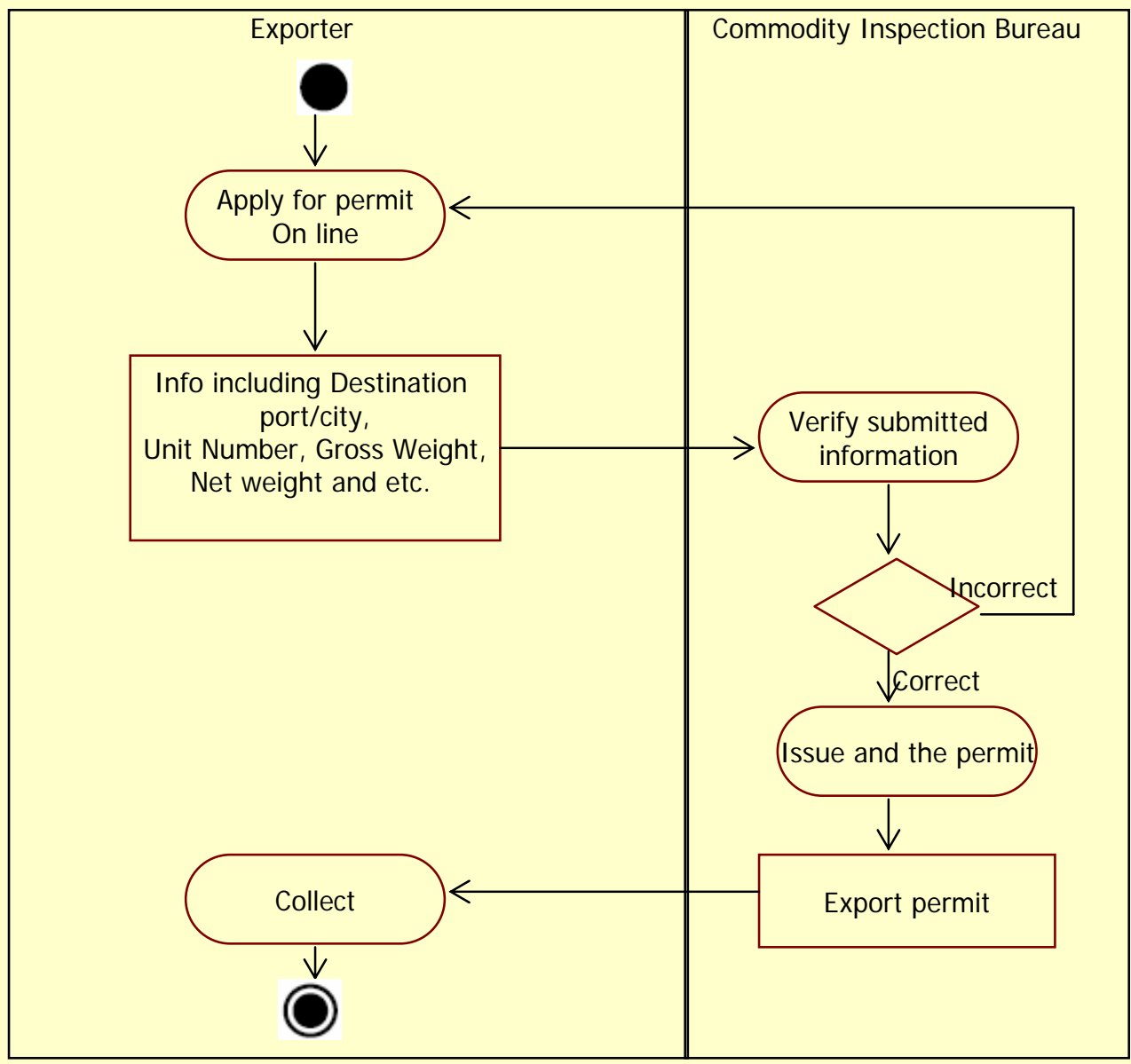


2.2 Arrange transport

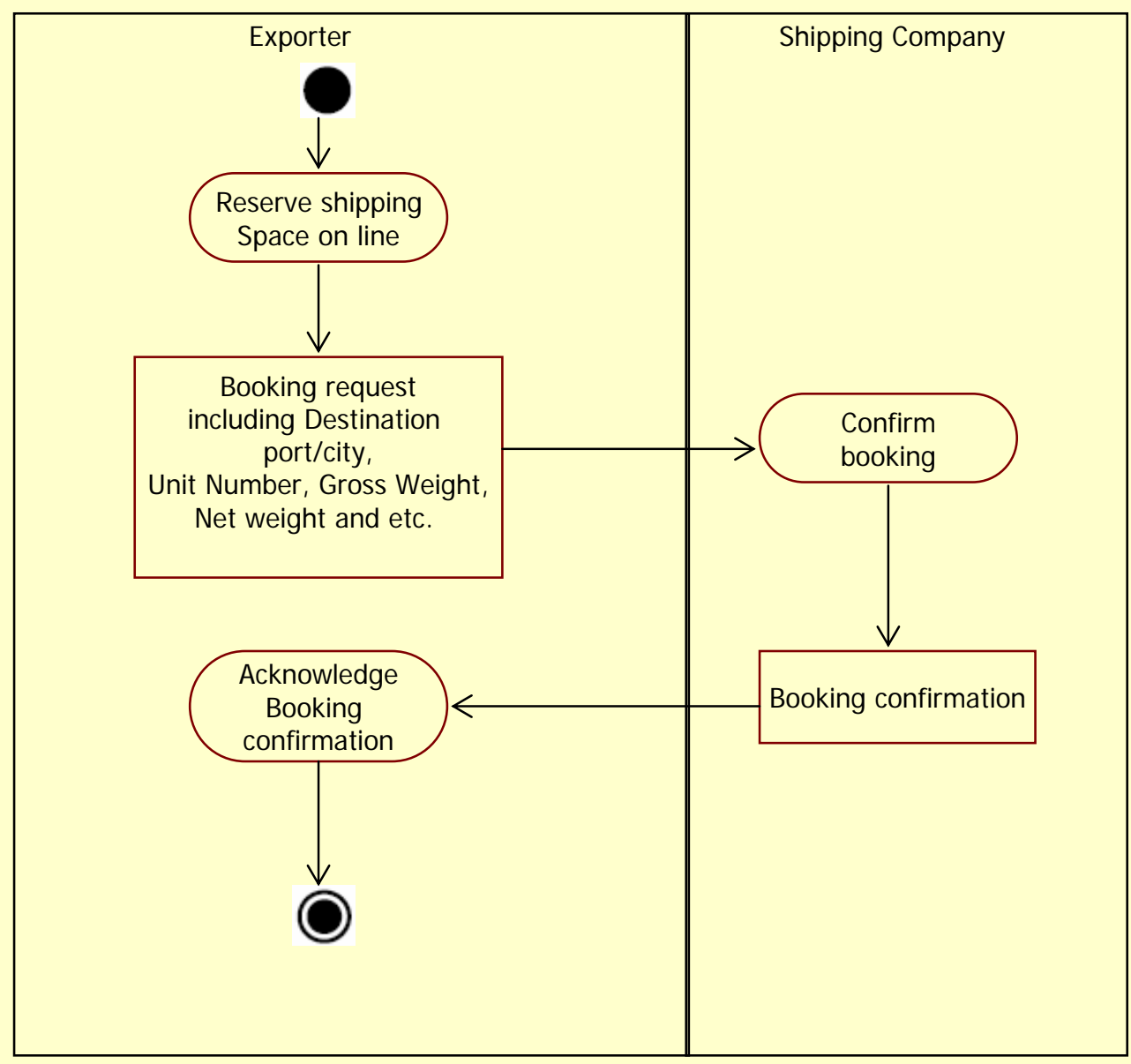




\subsection{Arrange Inspection for clients}

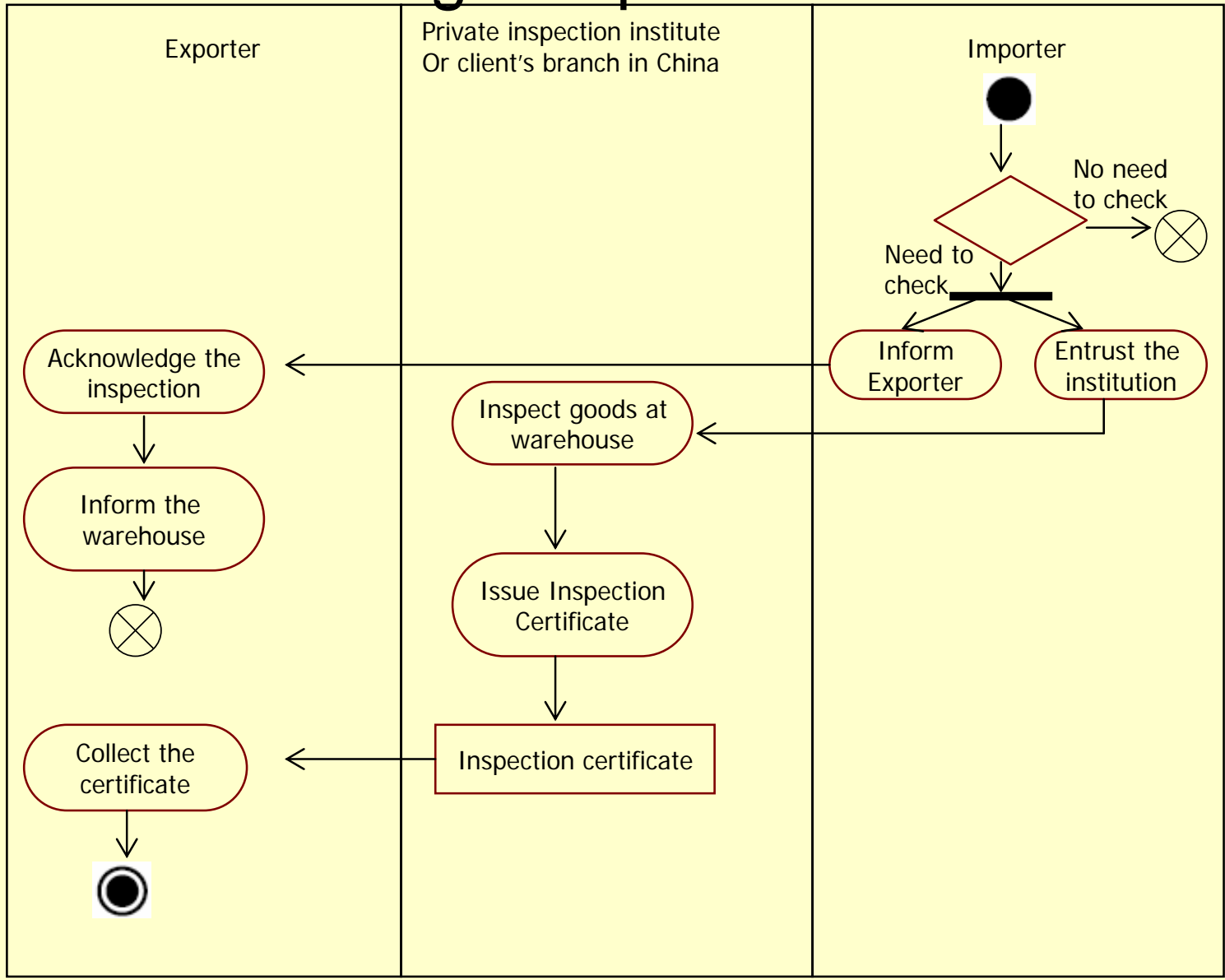




\subsection{Prepare customs declaration}

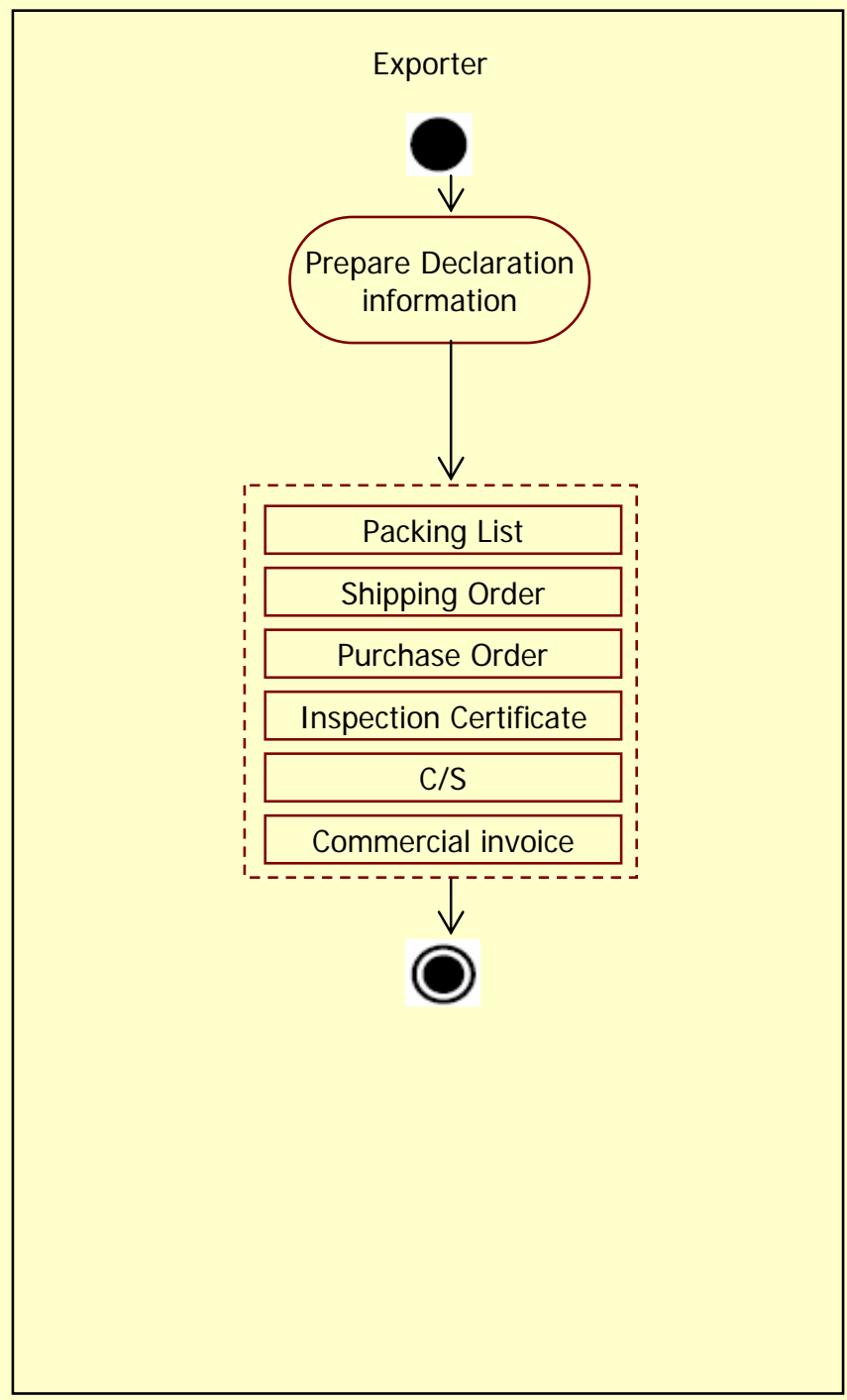




\subsection{Collect empty containers from yard}

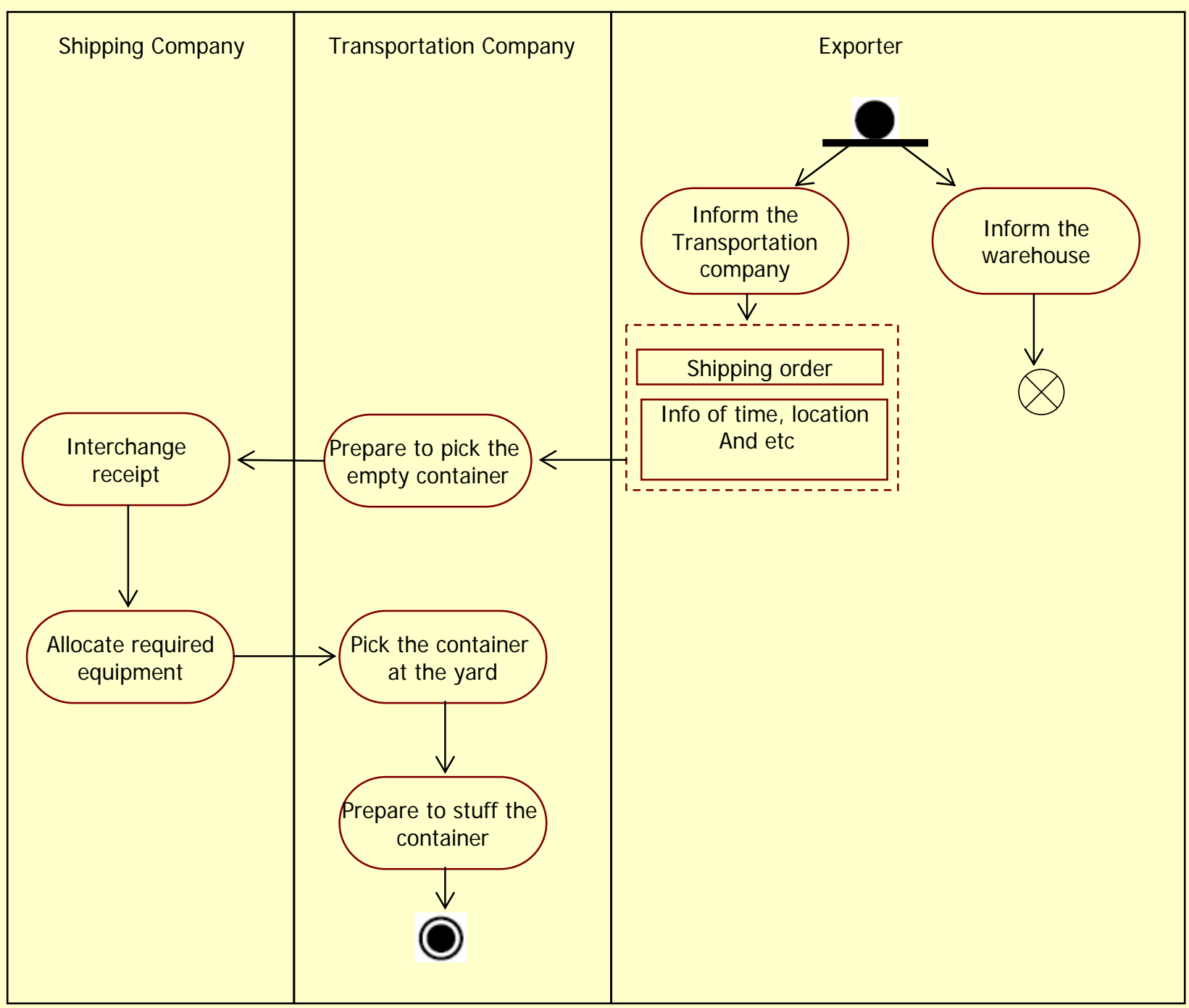


2.6 Stuff a container

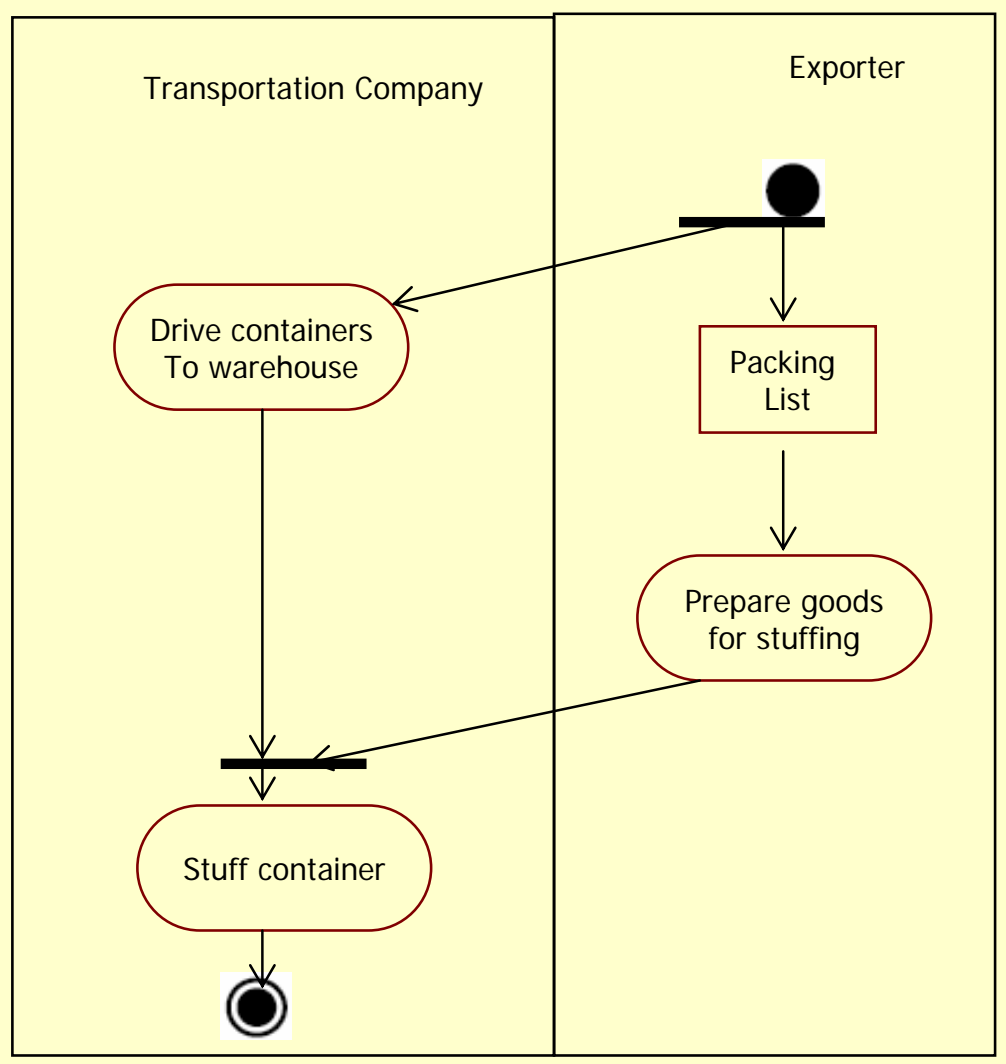




\subsection{Transport to port of departure}

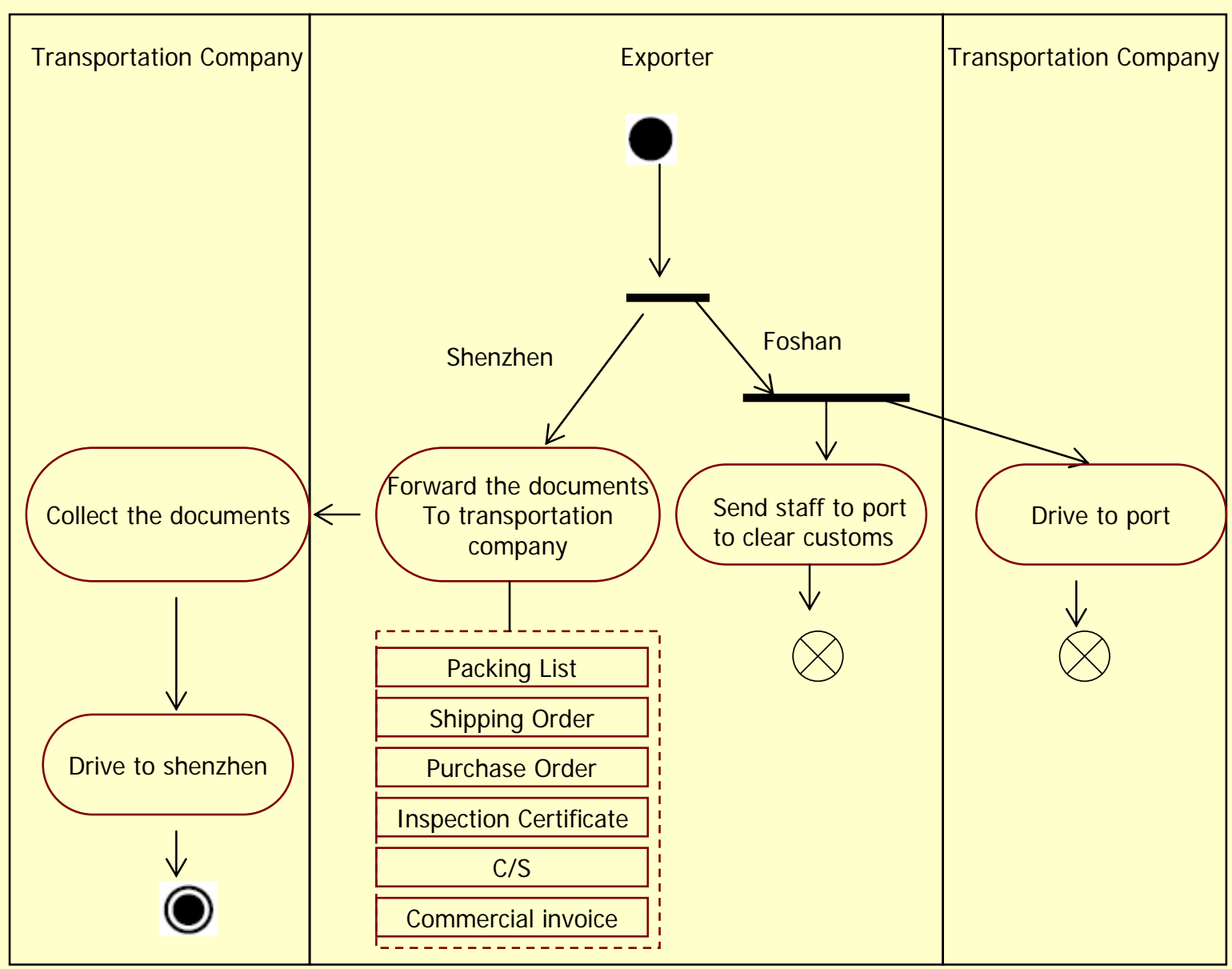


2.8 Clear goods through customs (container)

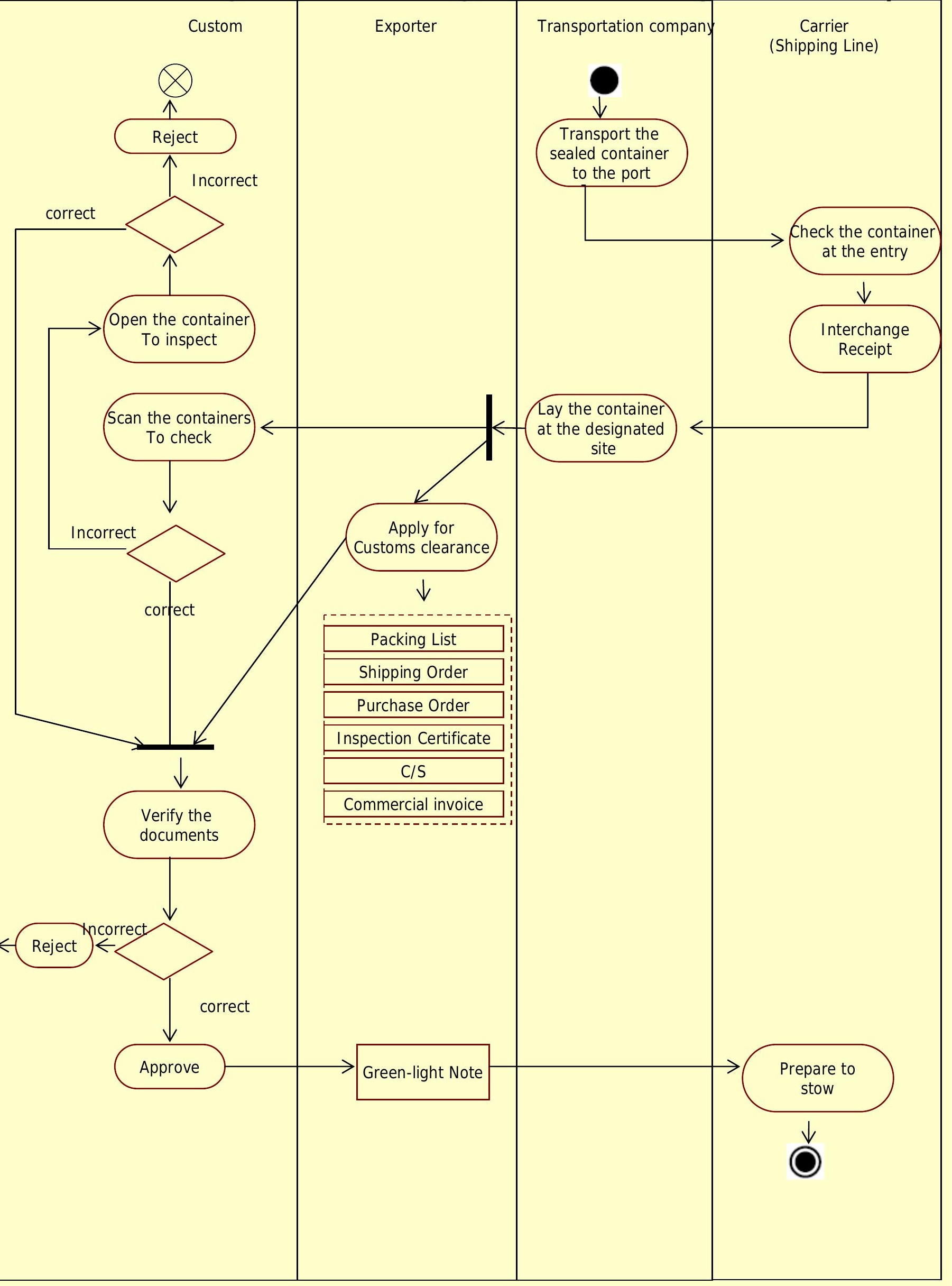




\subsection{Handle container and stow on vessel}

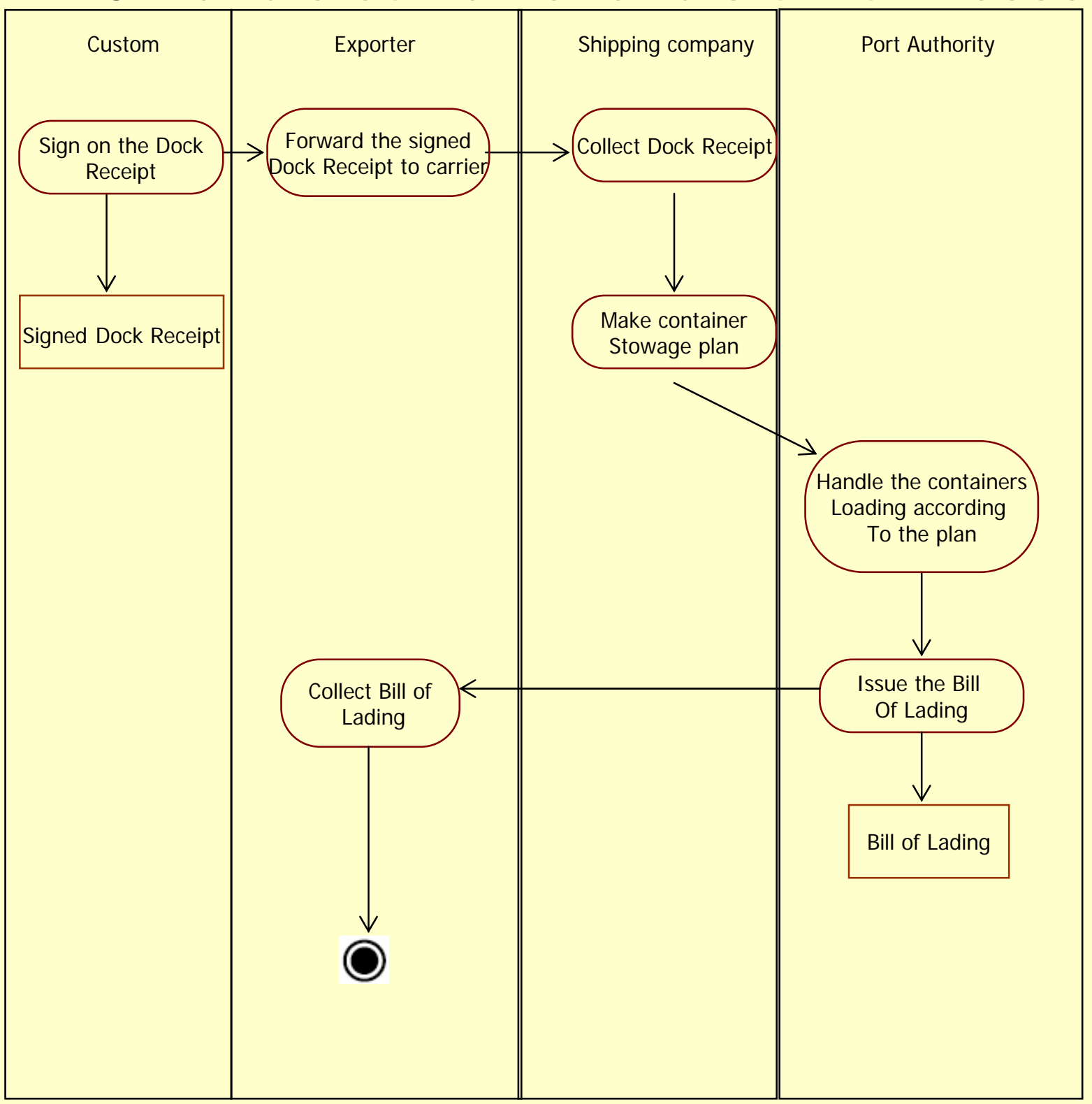




\subsection{Obtain cargo insurance}

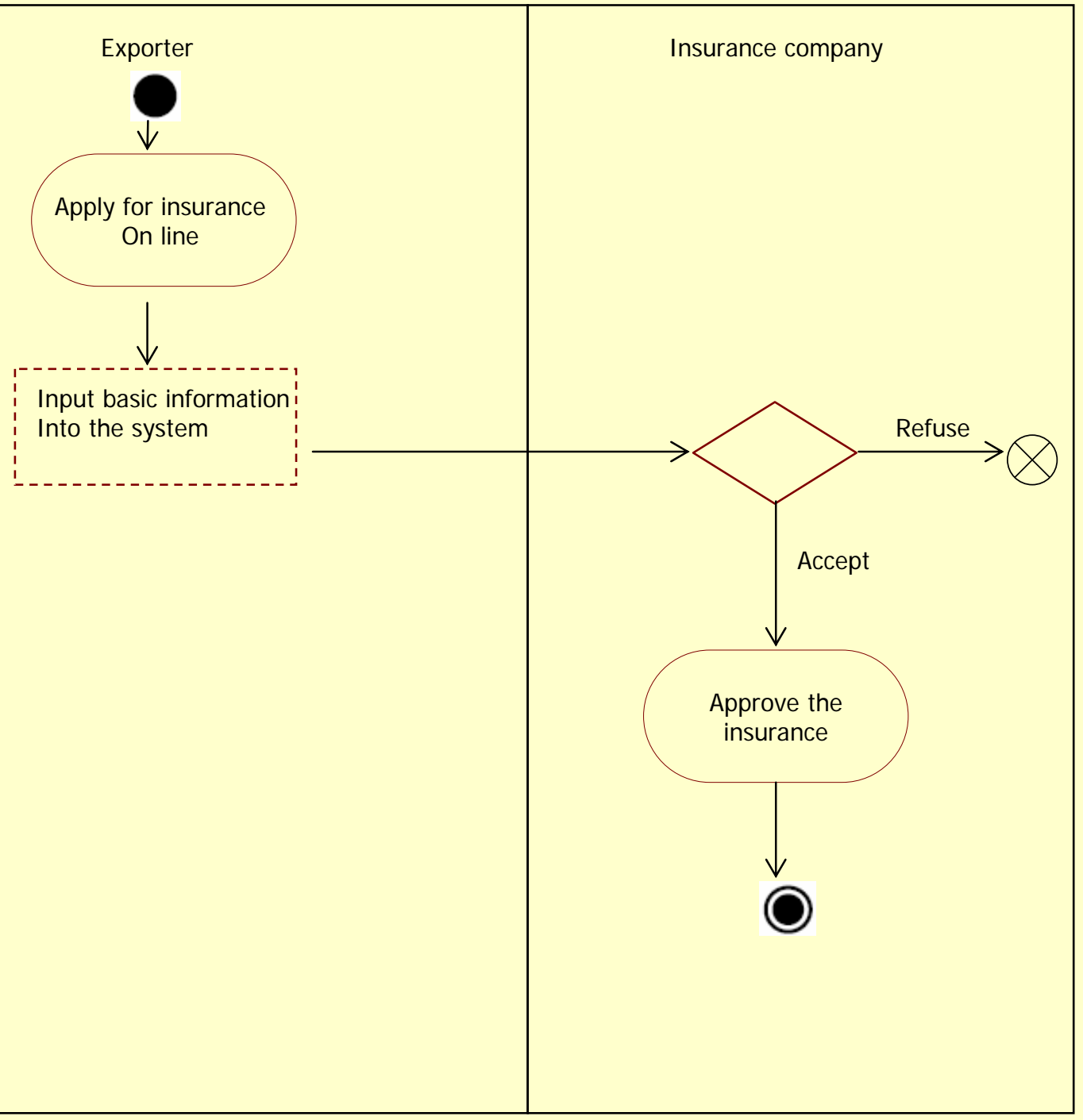




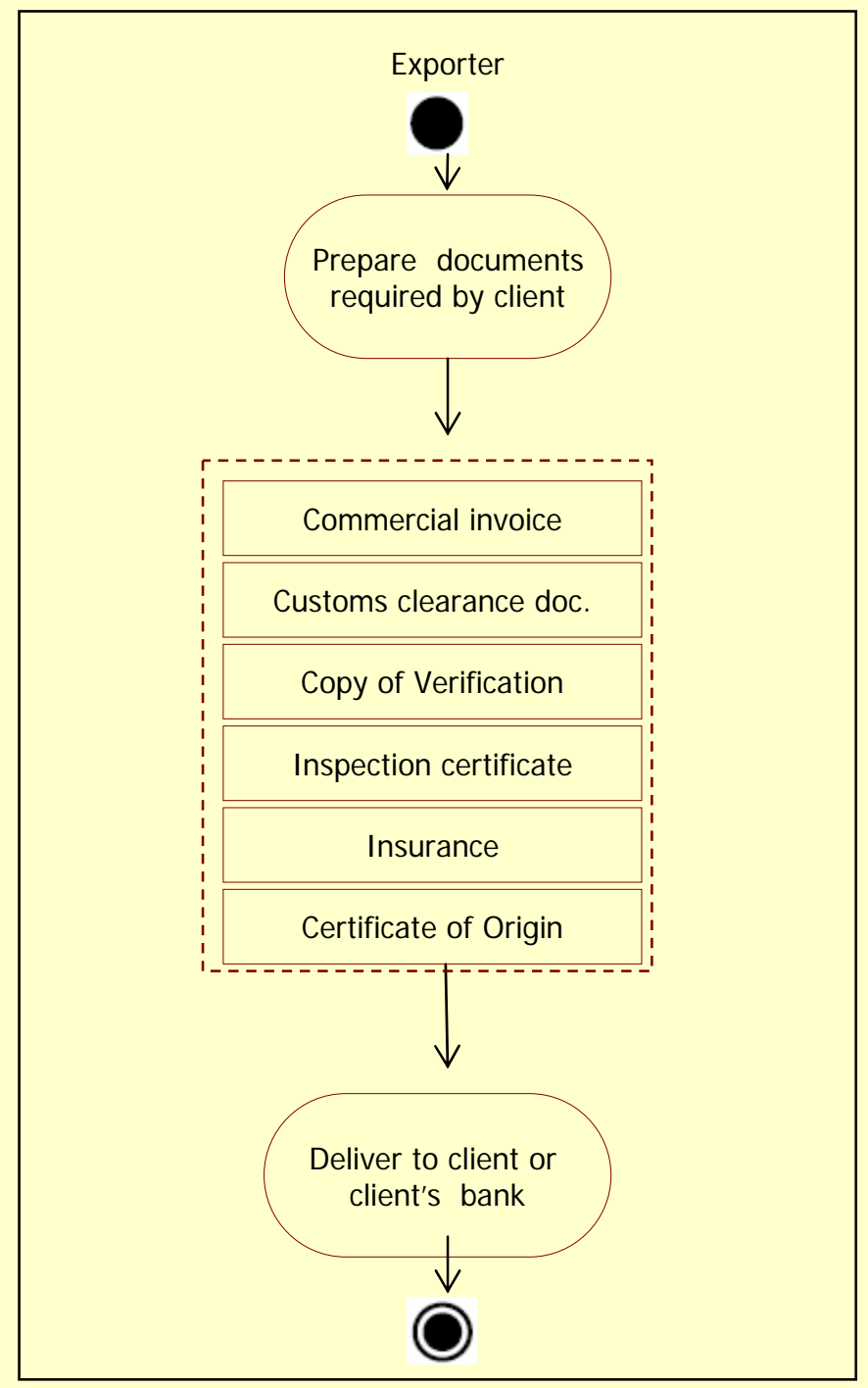


3. Pay

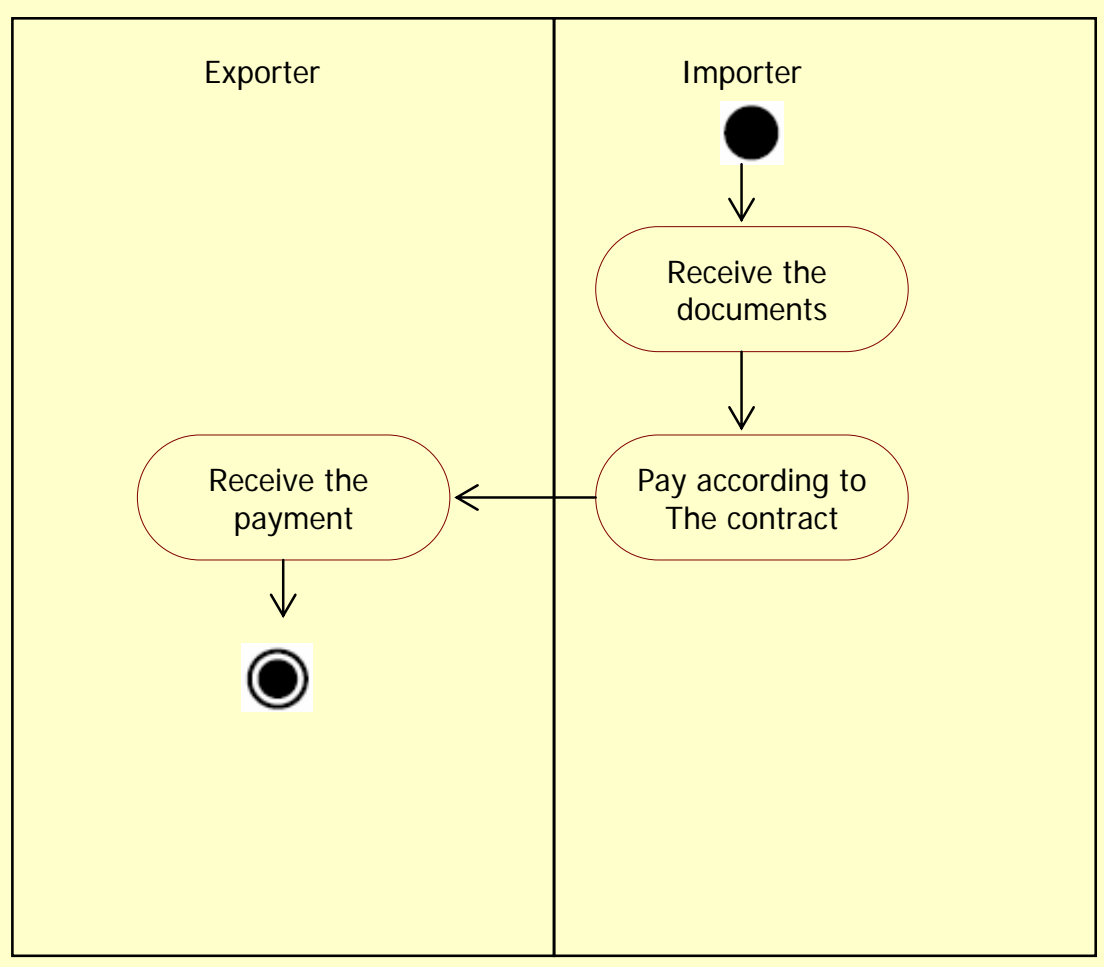




\section{Appendix 4}

Business Processes of

Textile Import from J apan 


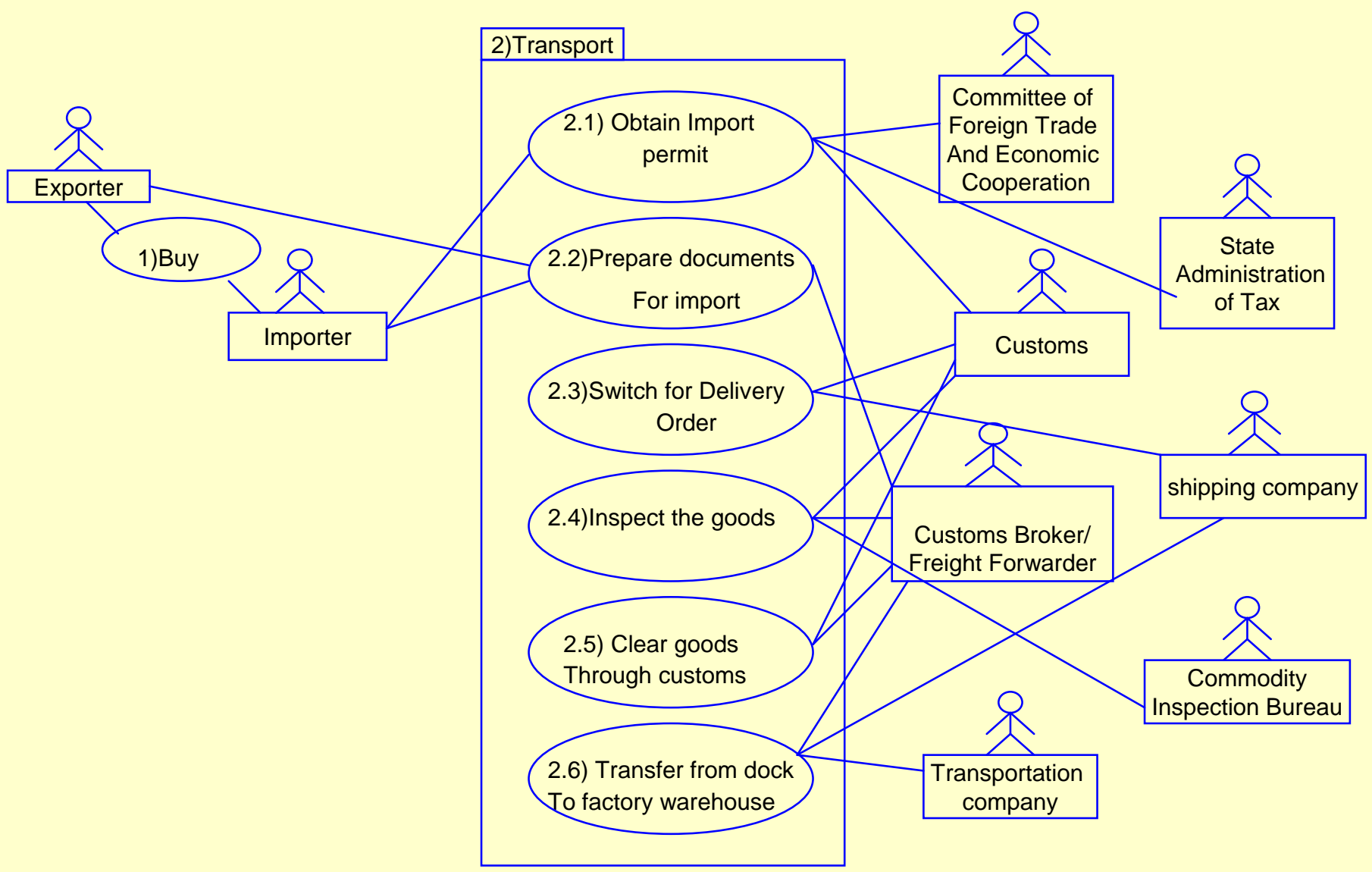


Overview of OEM import flow via agency

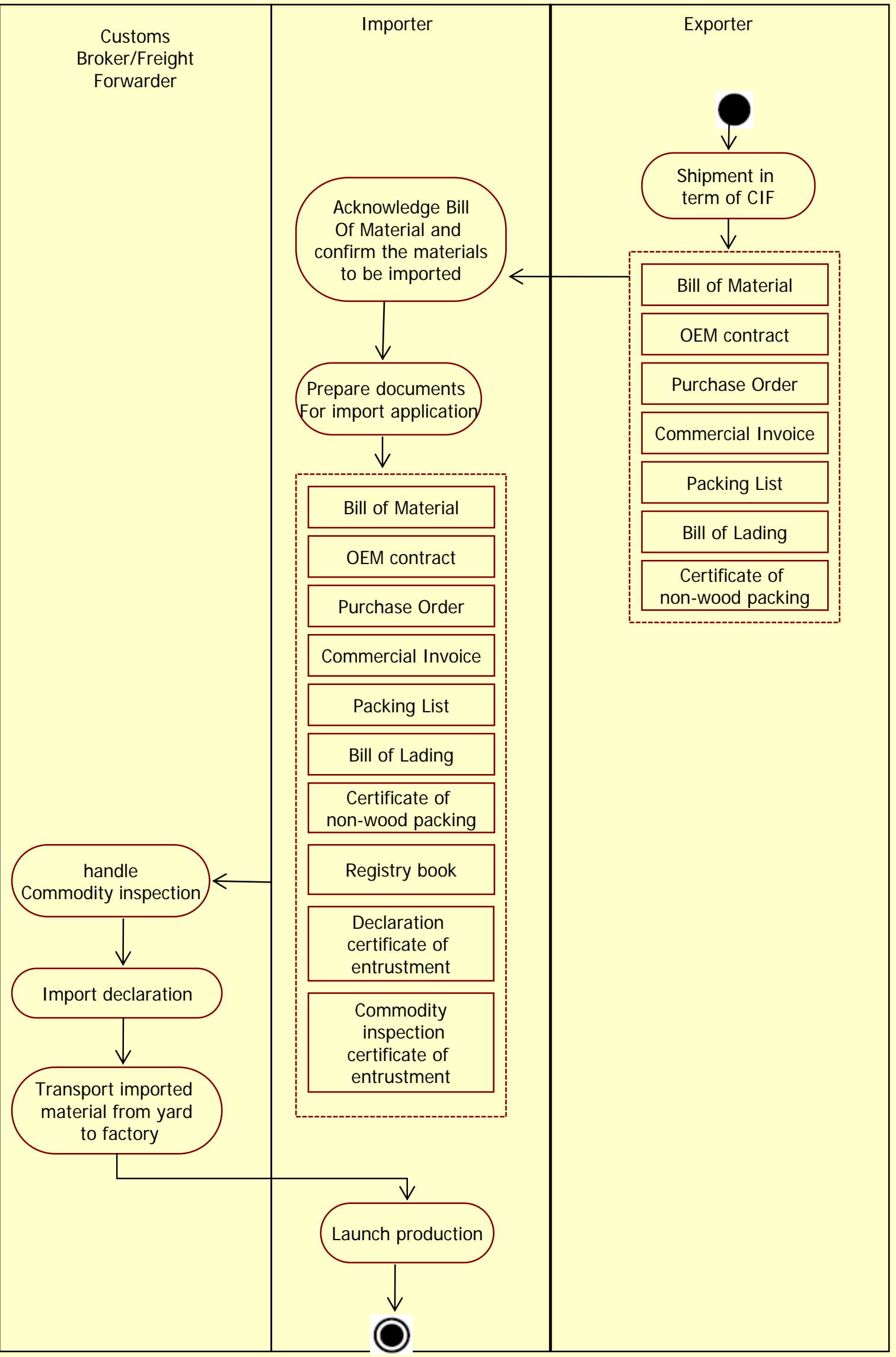




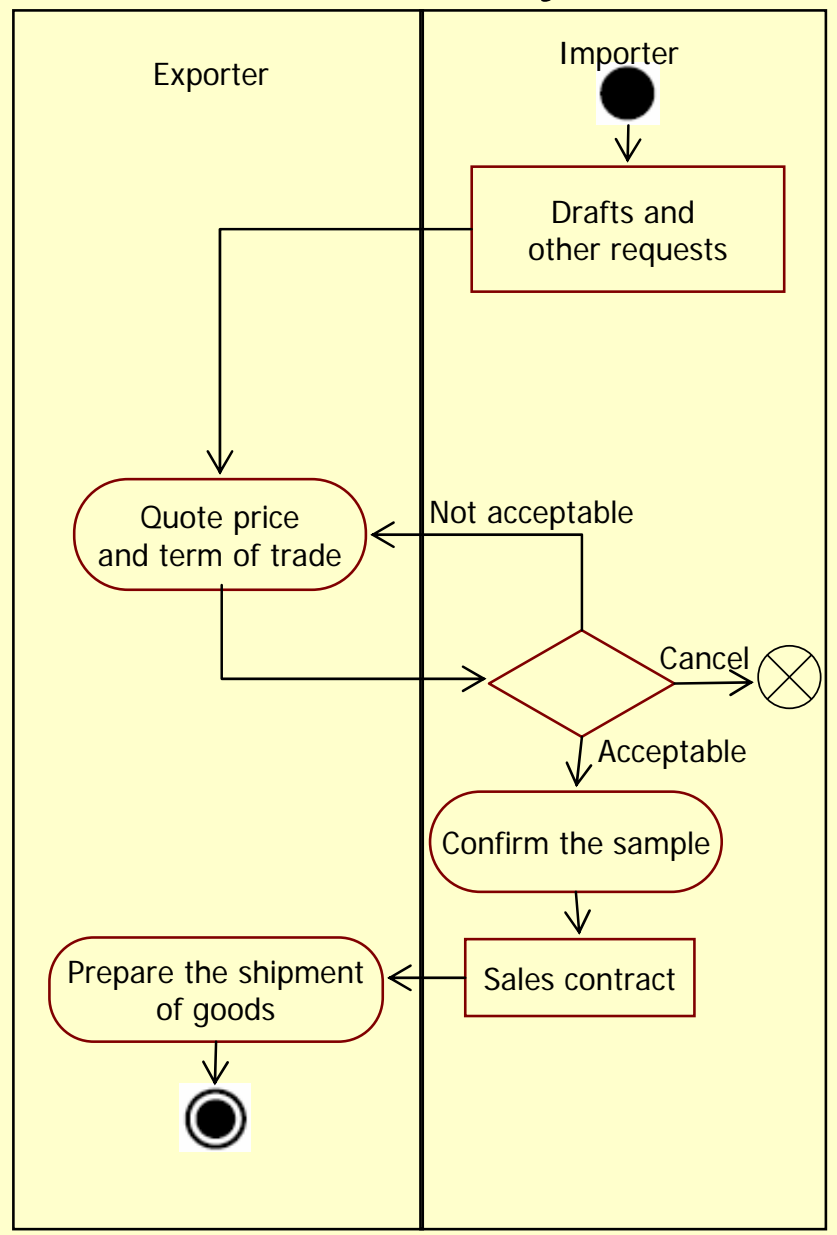


2.1 Obtain Import Permit

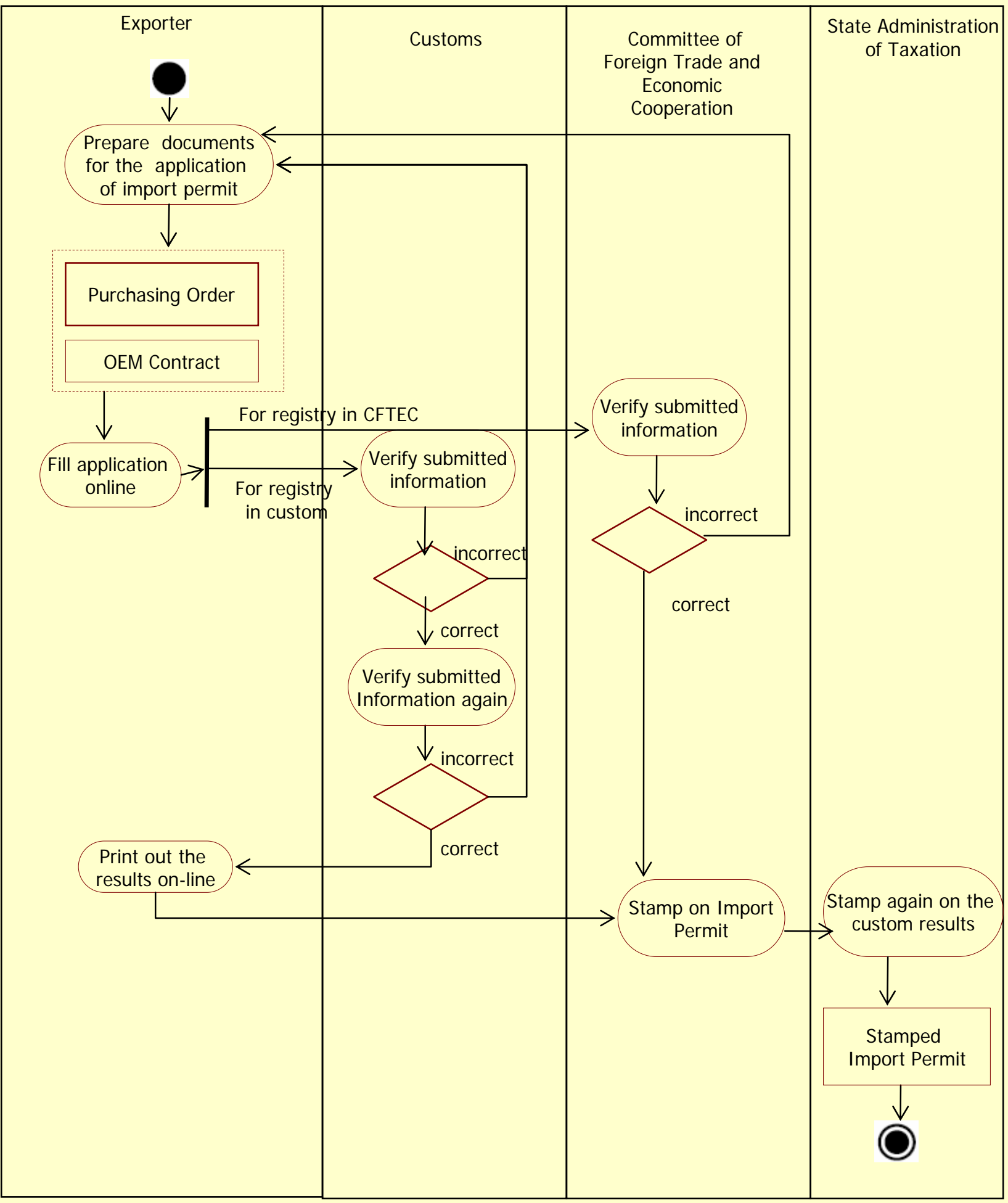


2.2 Prepare documents

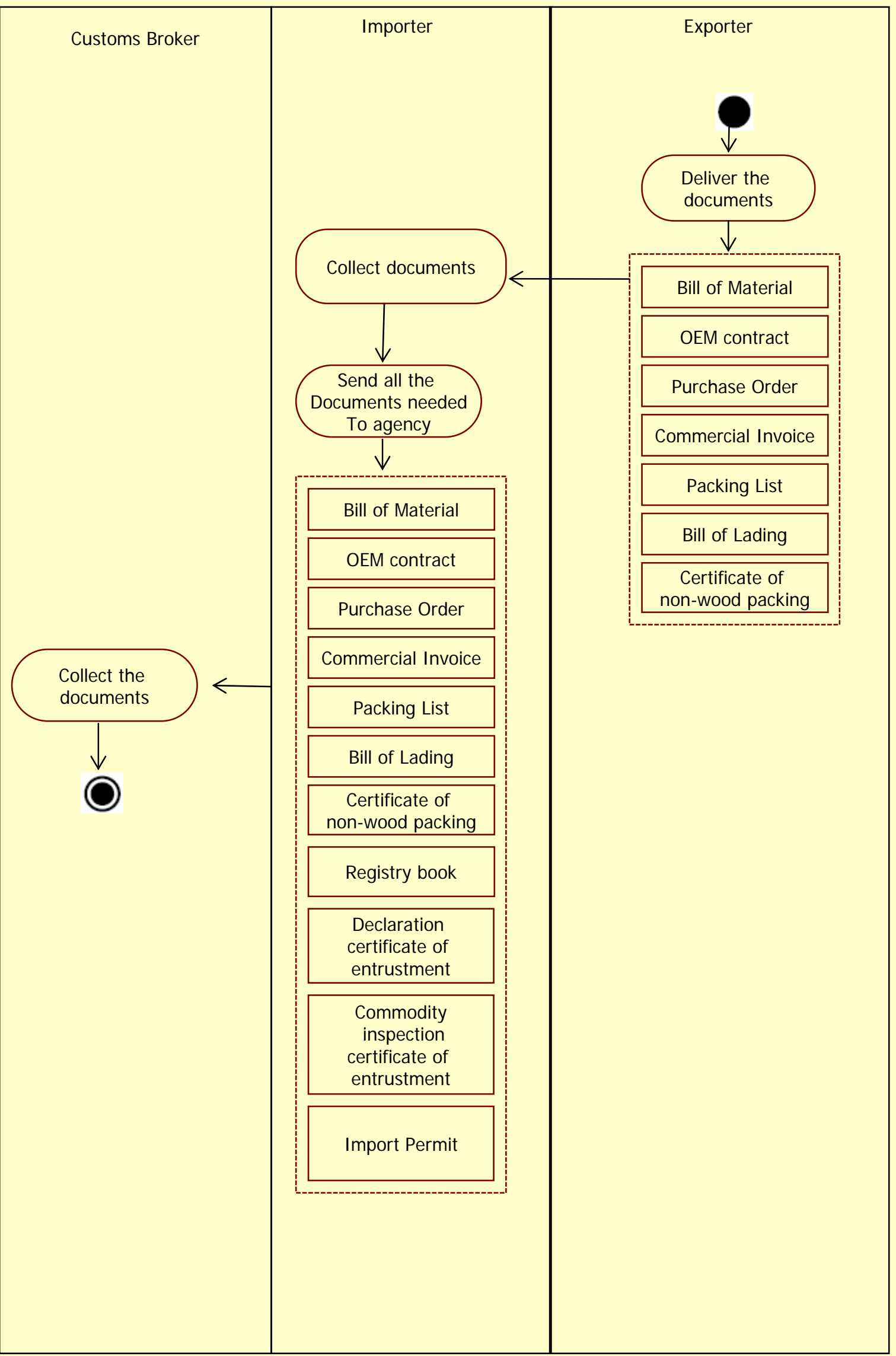


2.3 Switch for Delivery Order

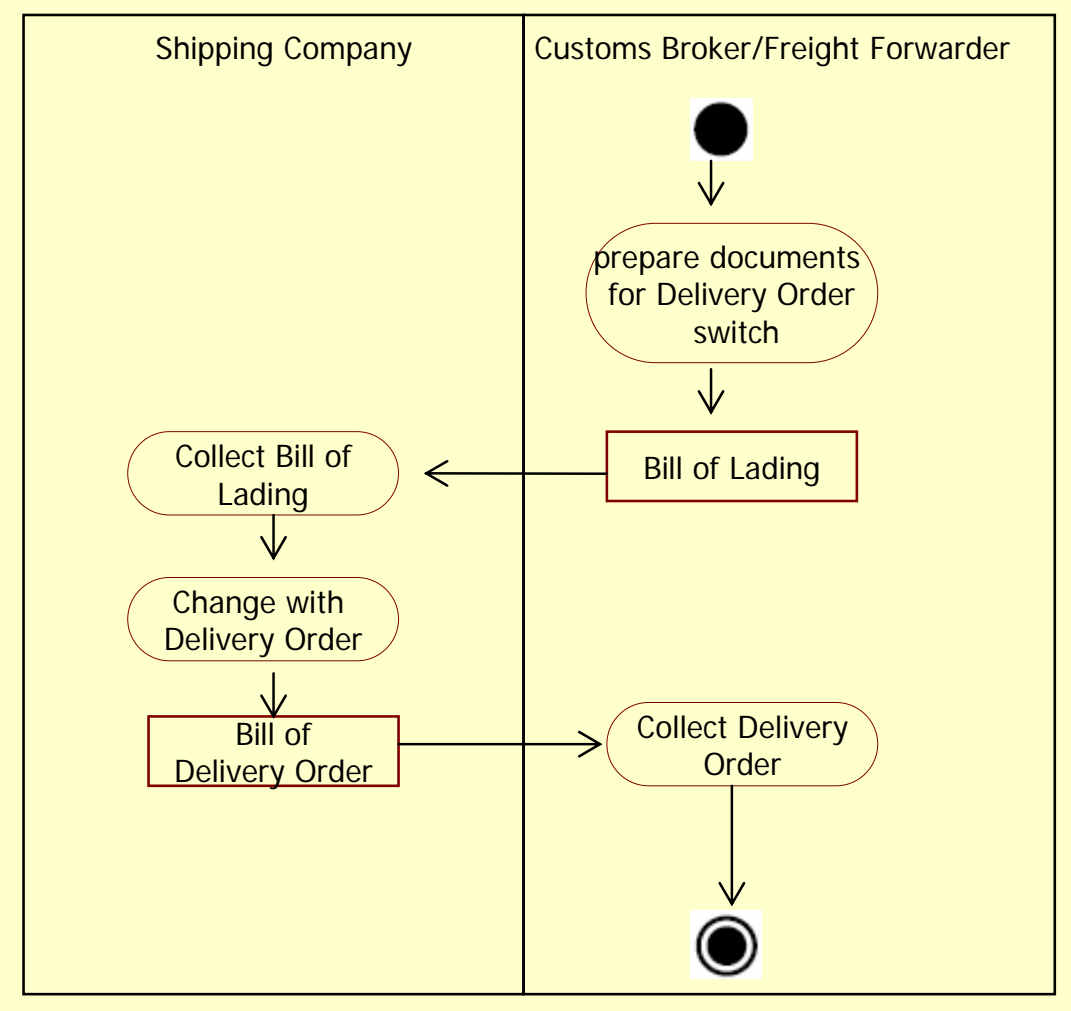




\subsection{Inspect the goods}

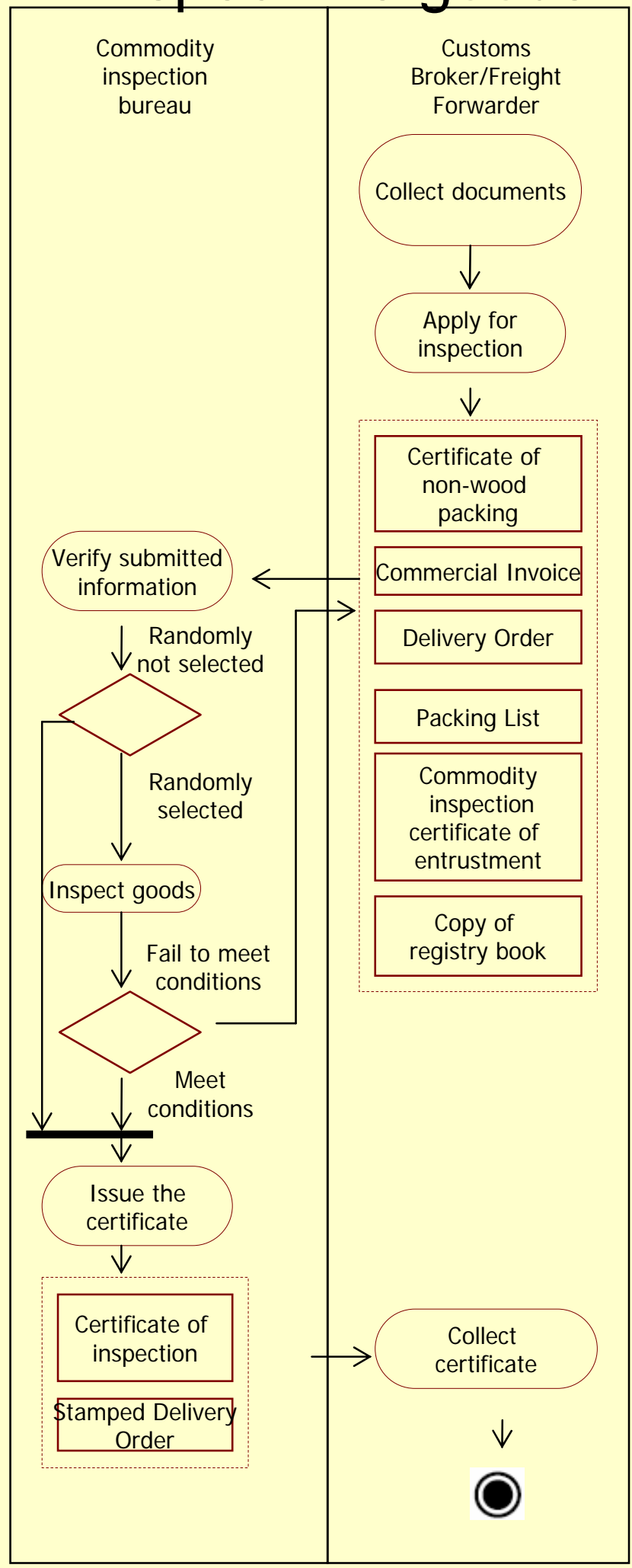


2.5 Clear goods through customs

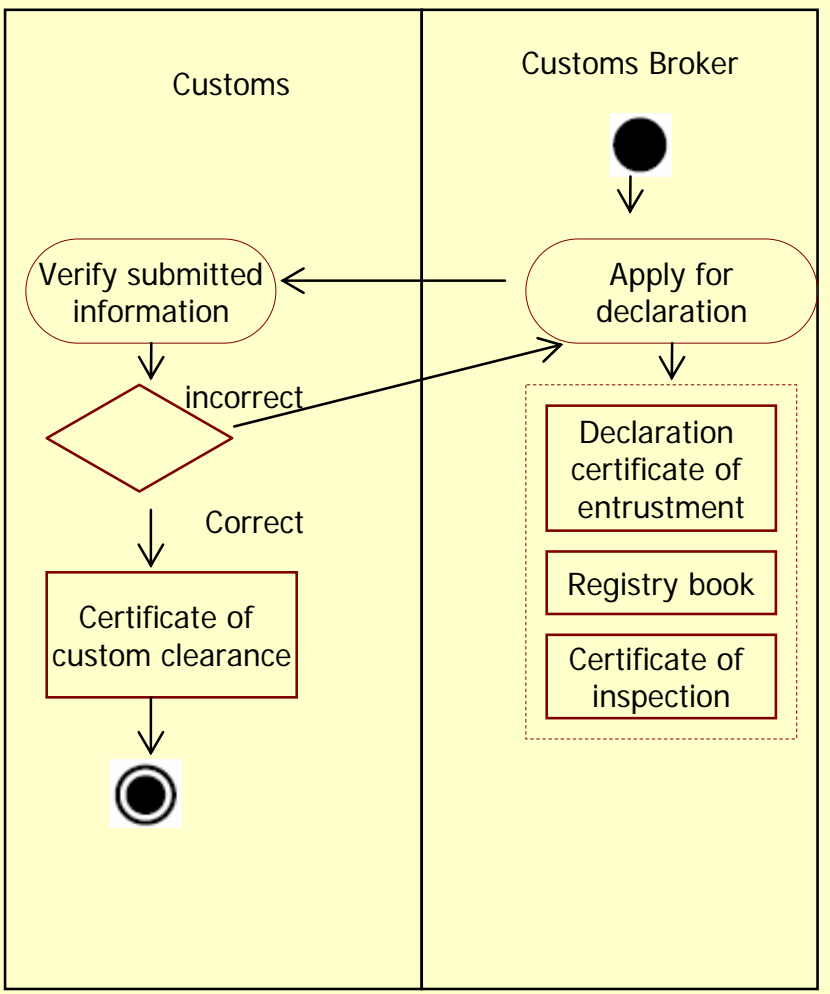




\subsection{Transport from dock to factory warehouse}

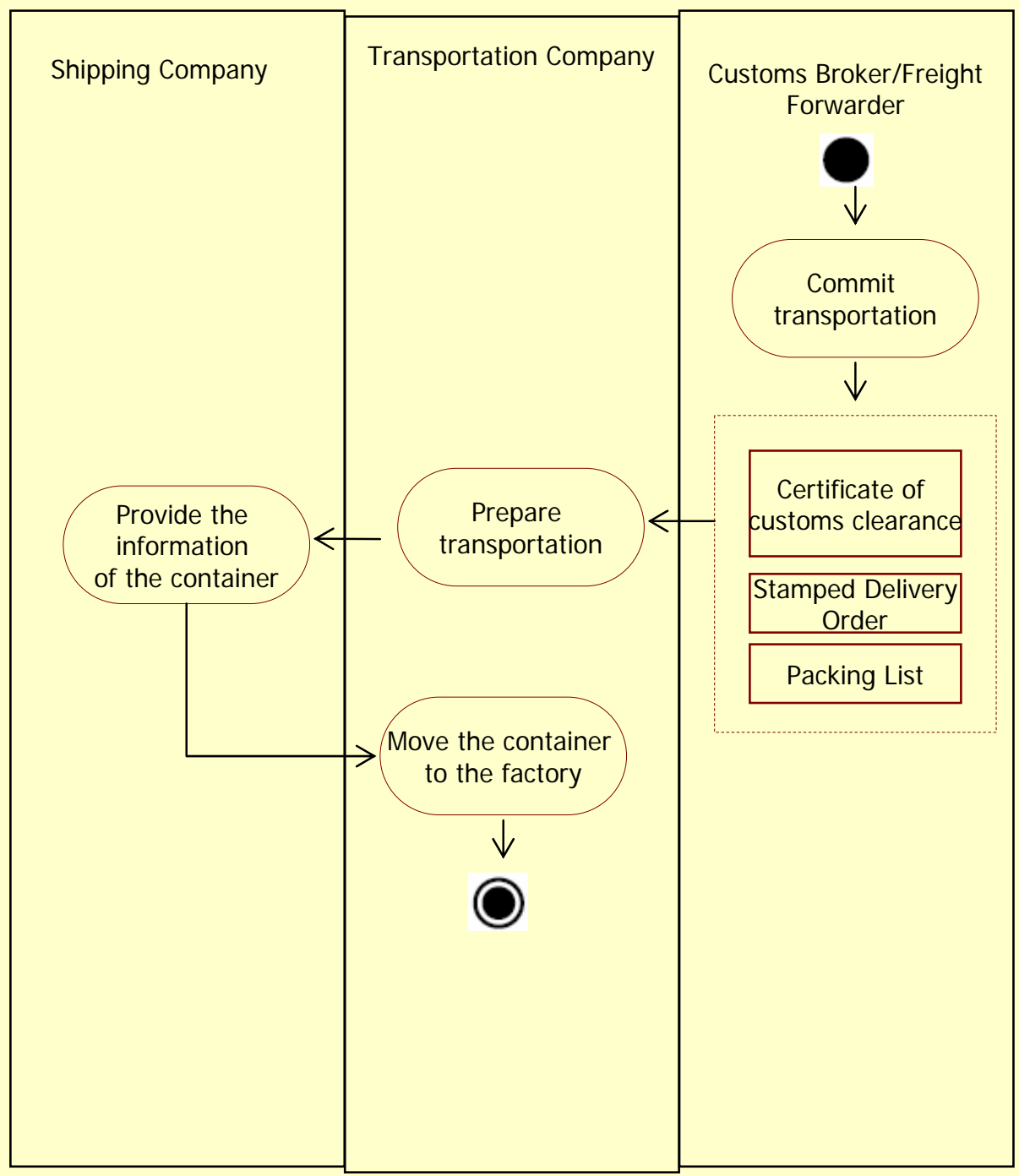




\section{Appendix 5}

Business Processes of

Auto Parts import from

Japan 


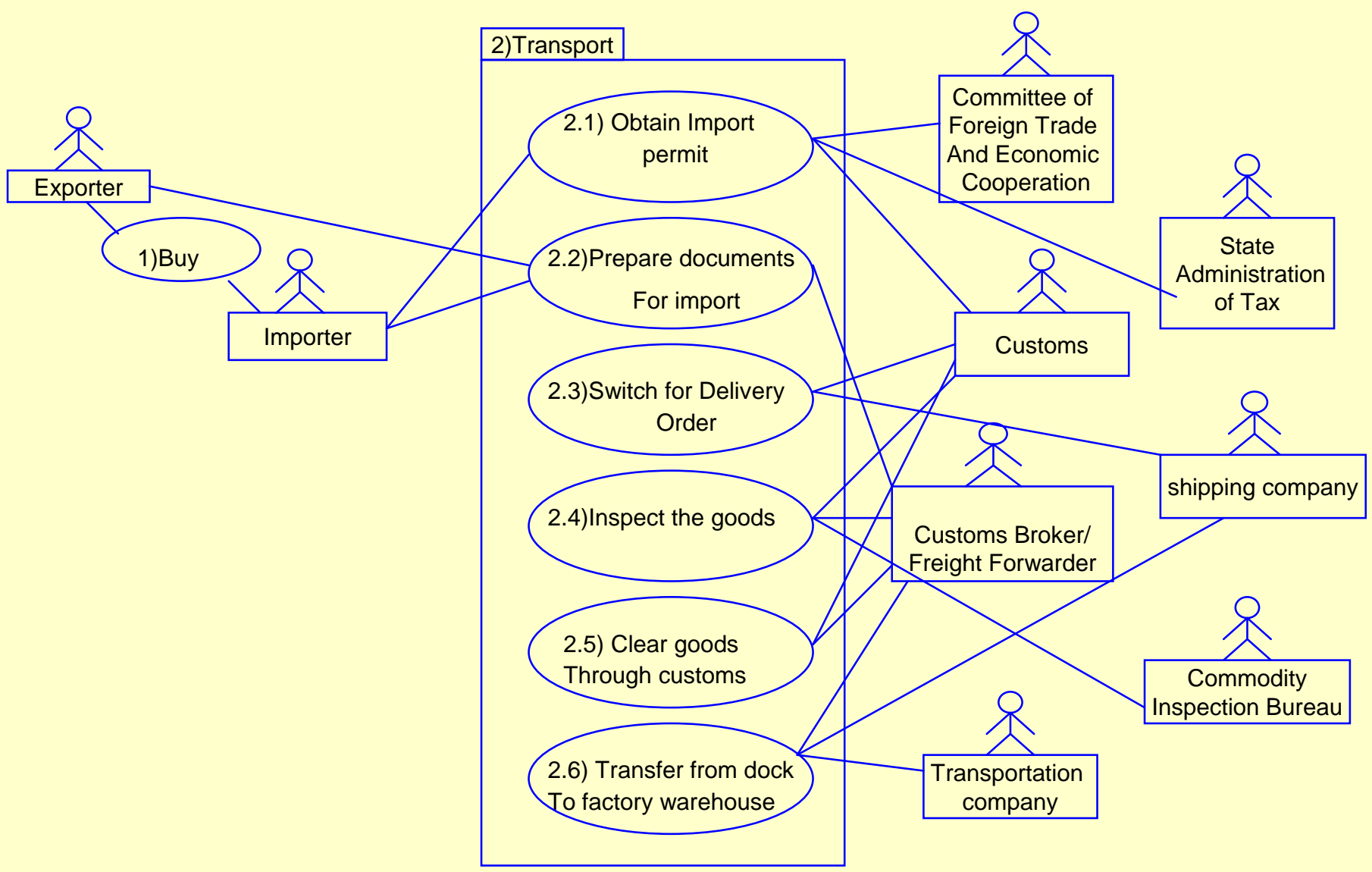




\section{Overview of OEM import flow via Freight Forwarder}

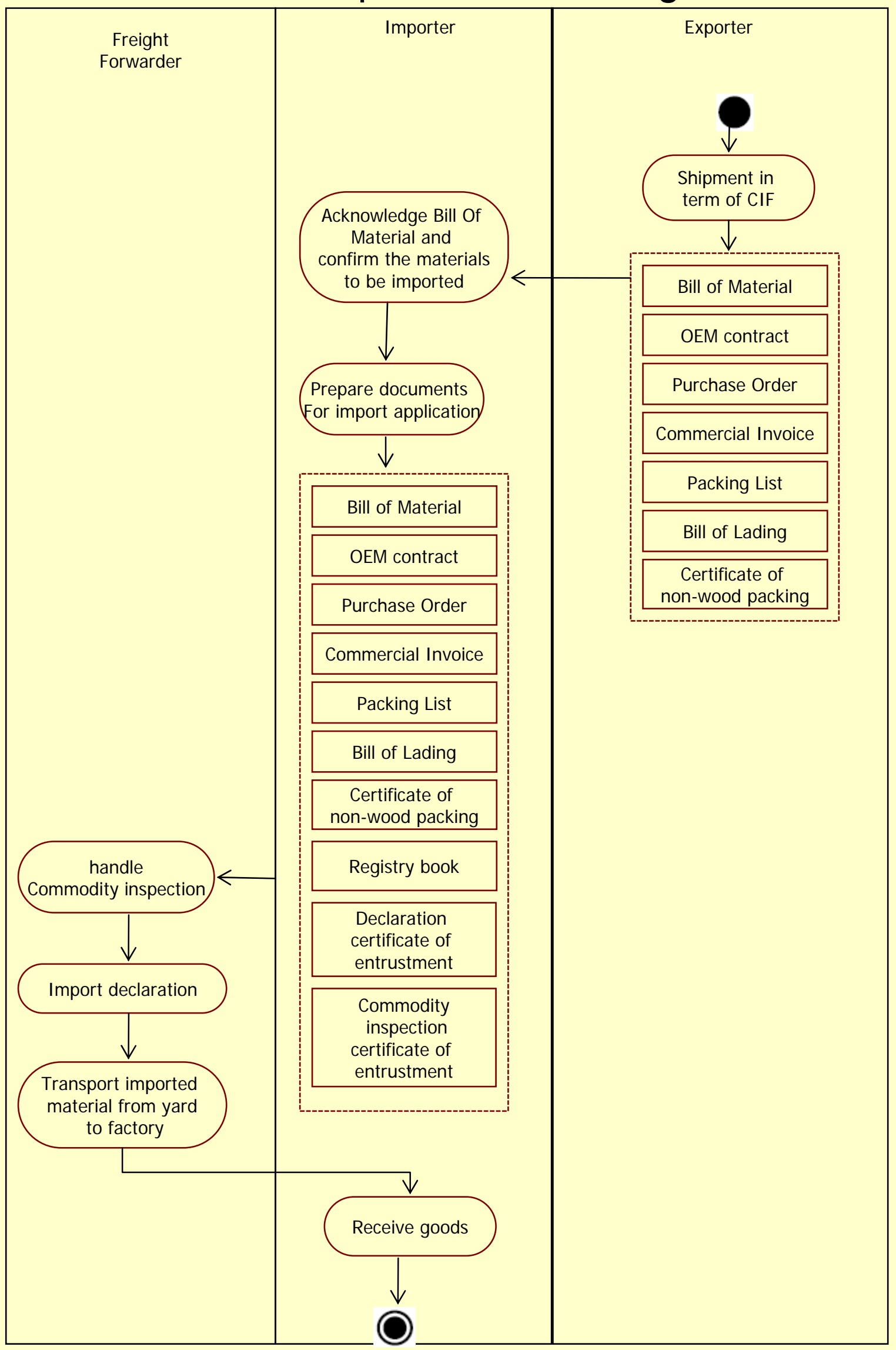




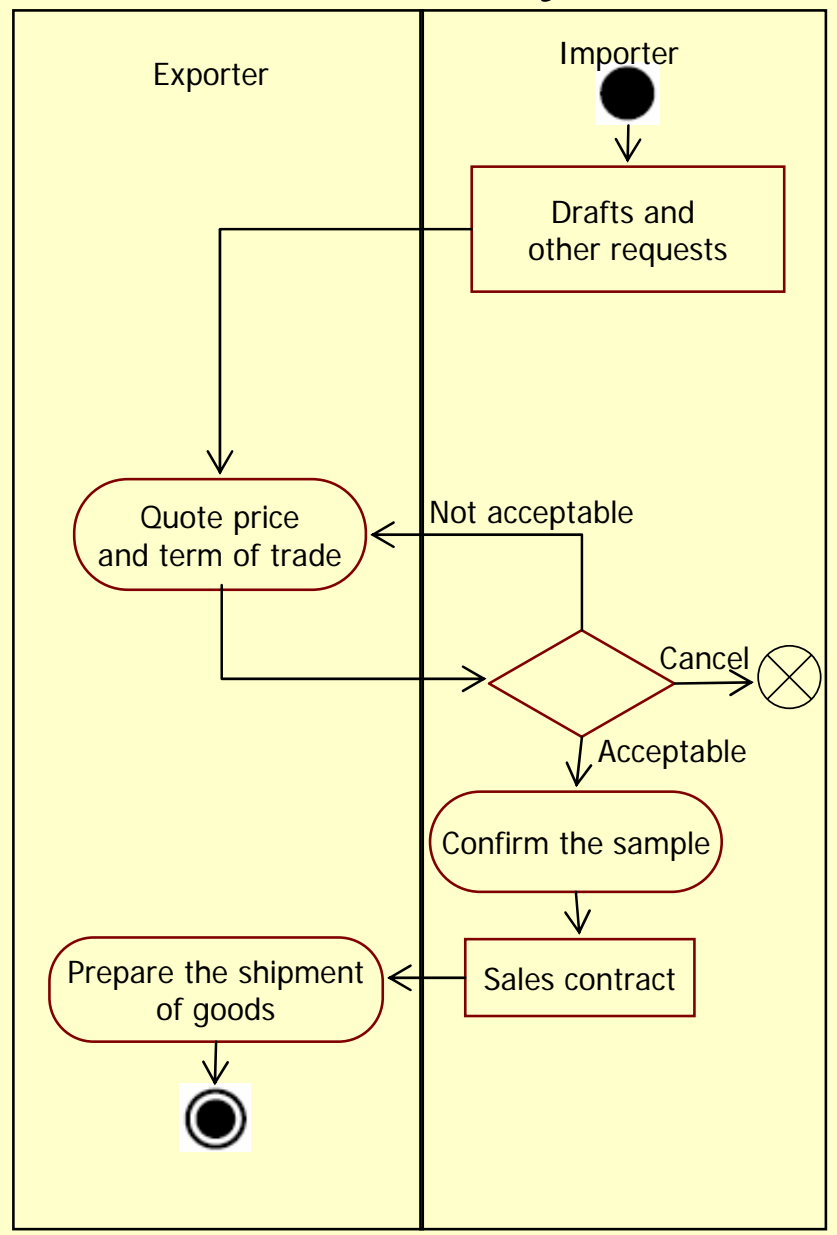


2.1 Obtain Import Permit

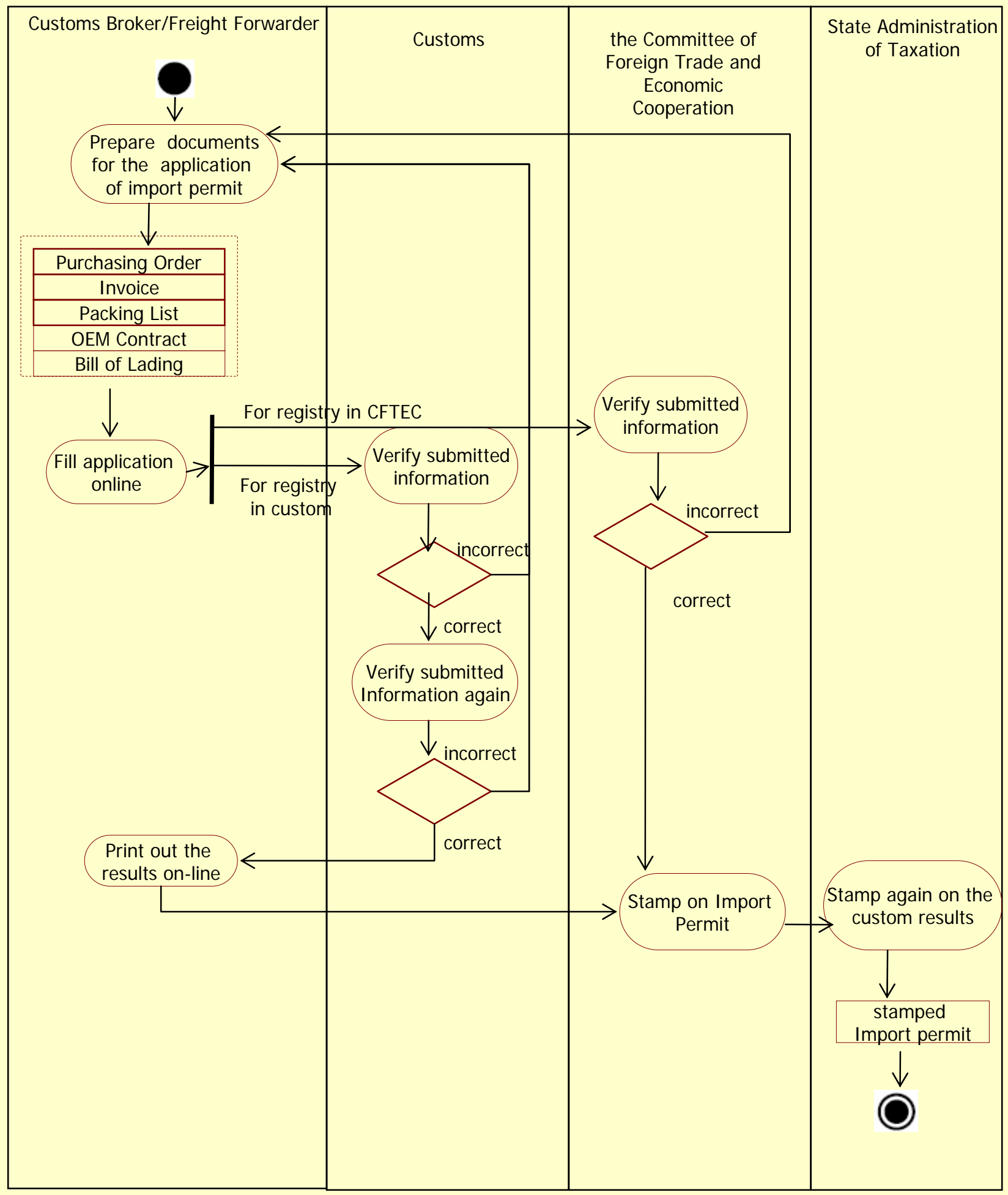


2.2 Prepare documents for import

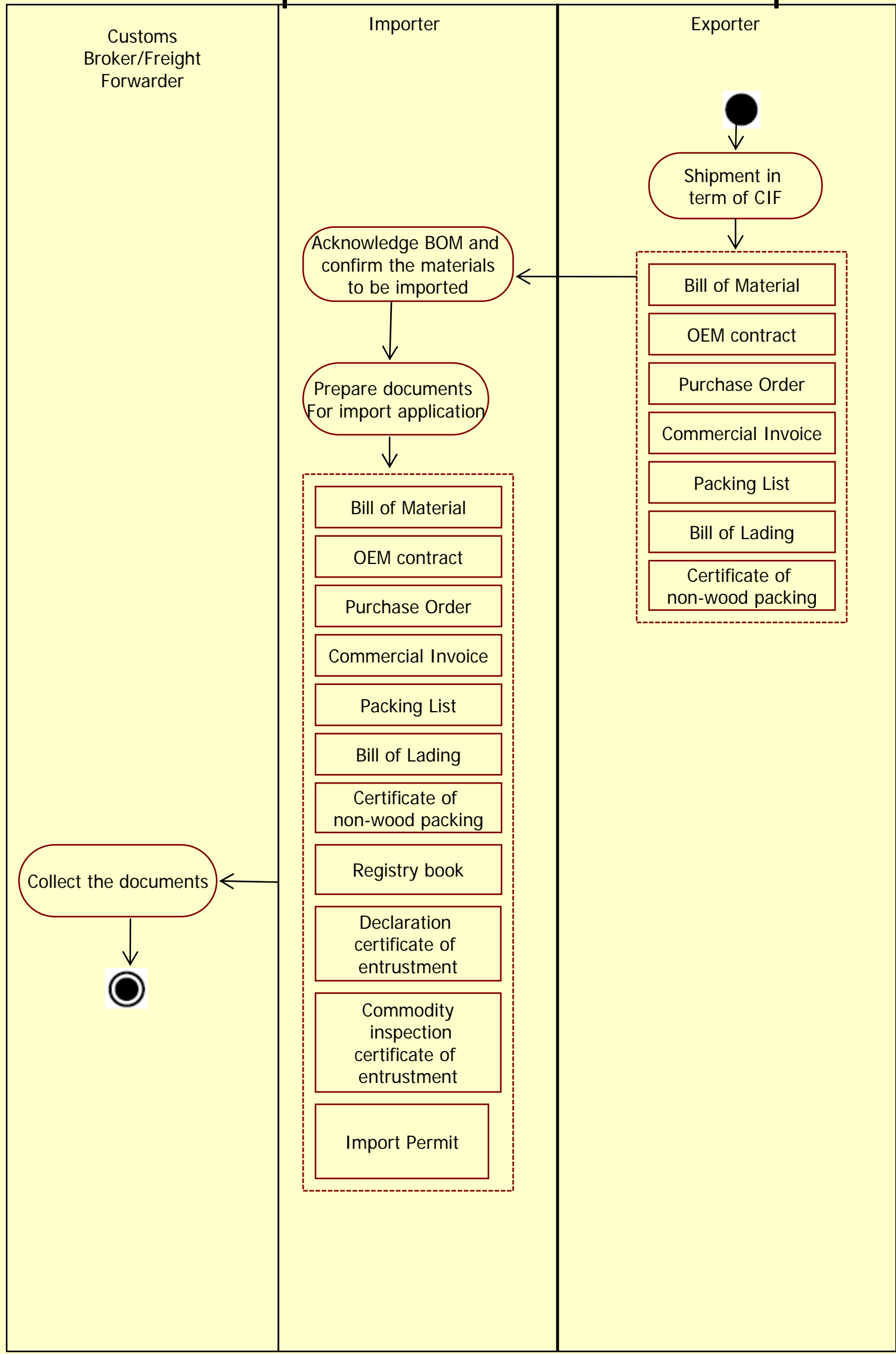




\subsection{Switch for Delivery Order}

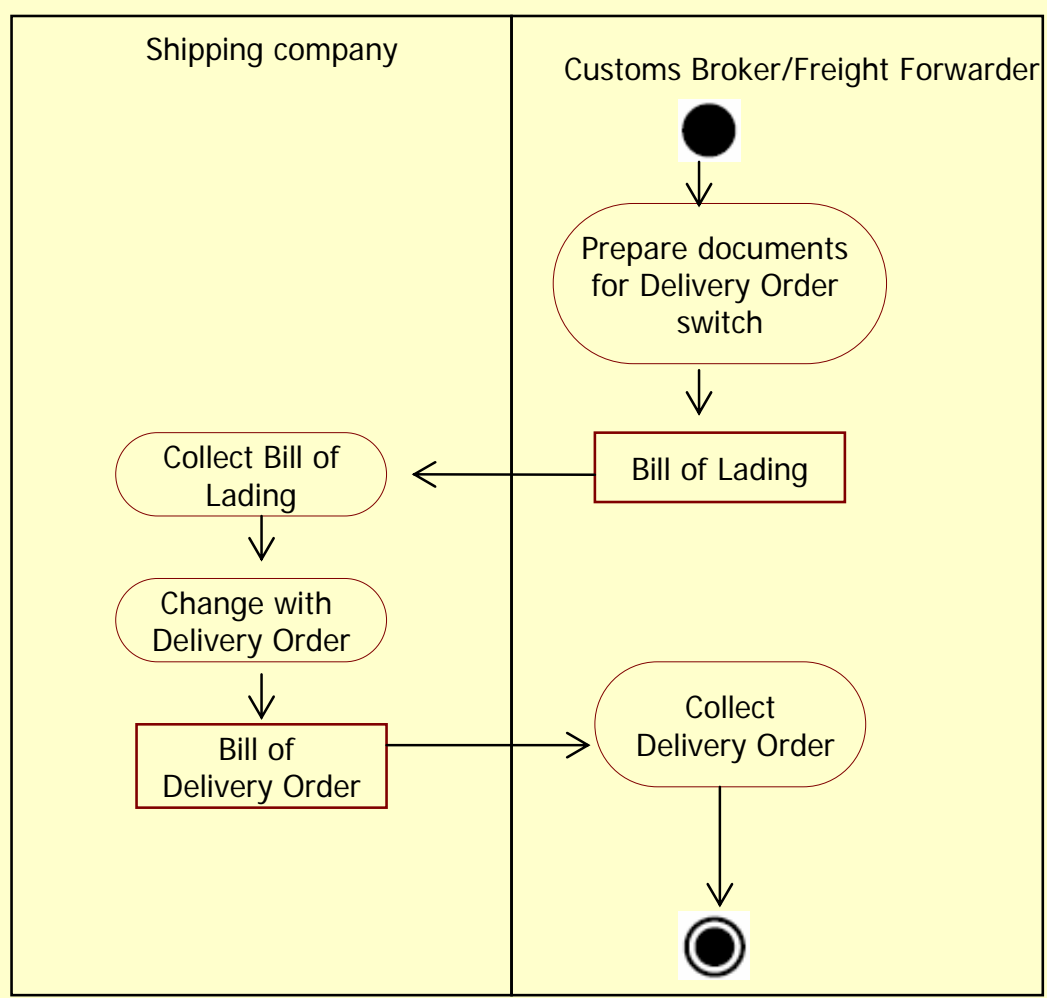




\subsection{Inspect the goods}

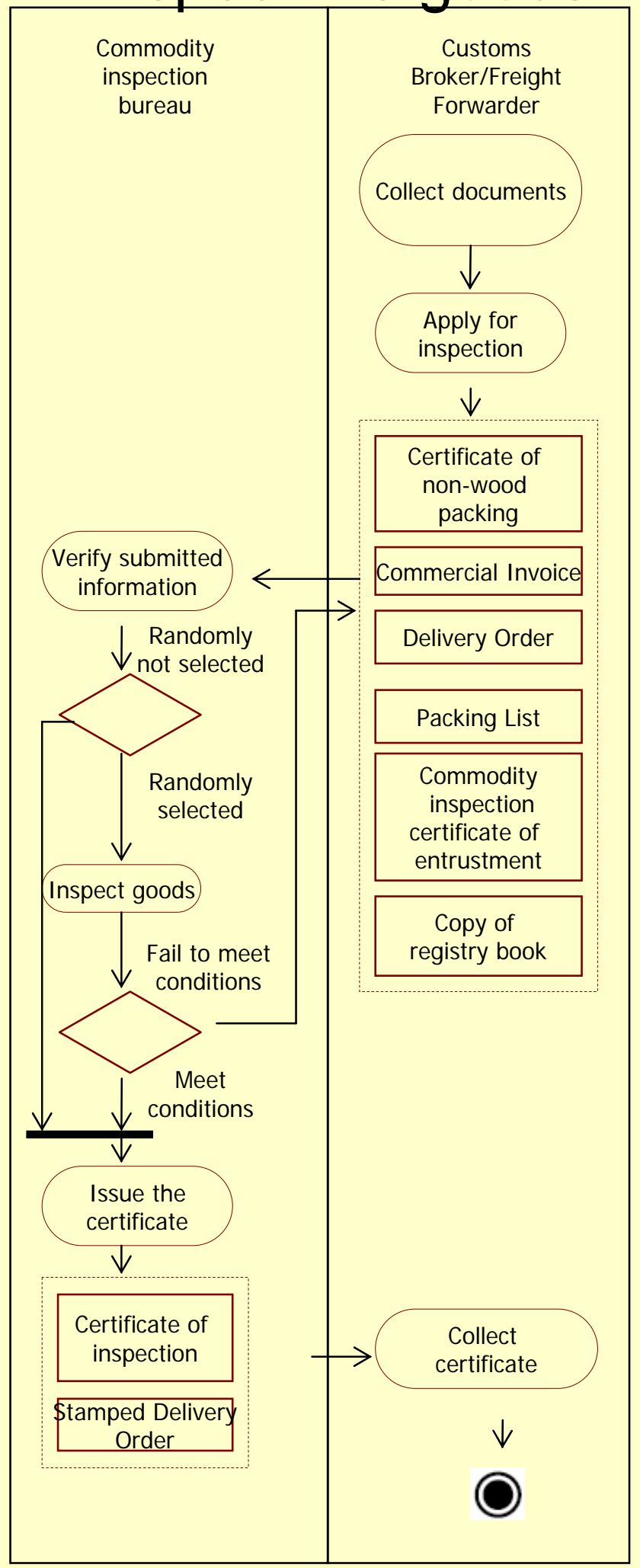


2.5 Clear goods through customs

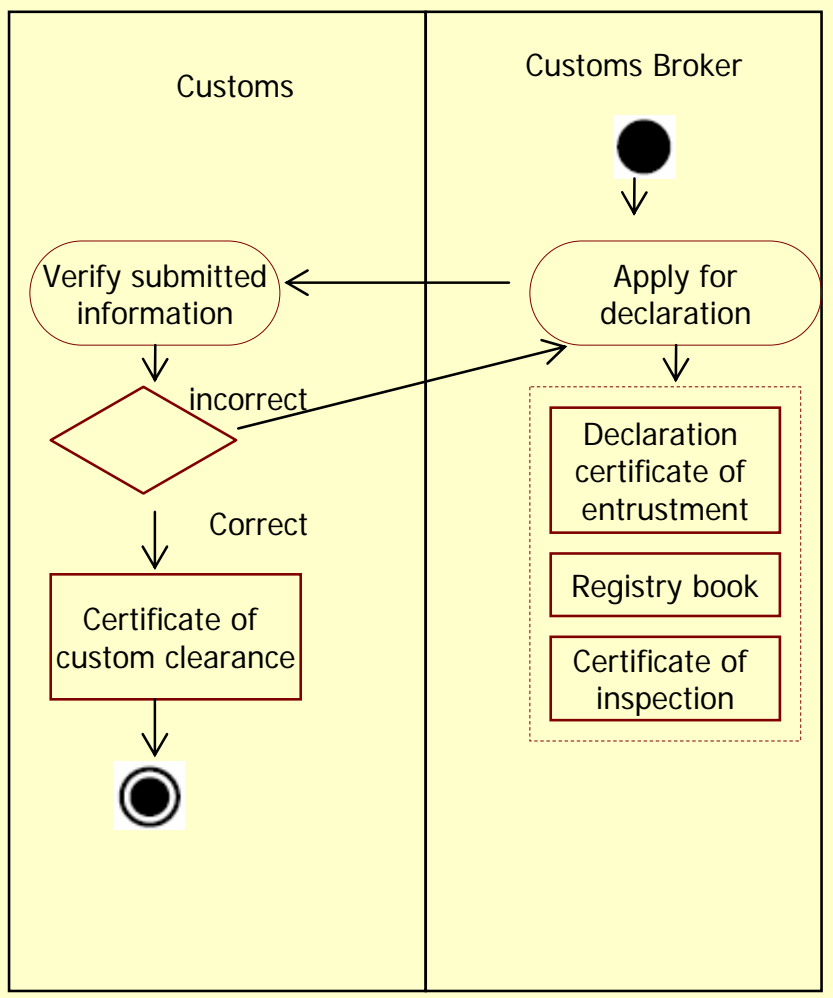




\subsection{Transport from dock to factory warehouse}

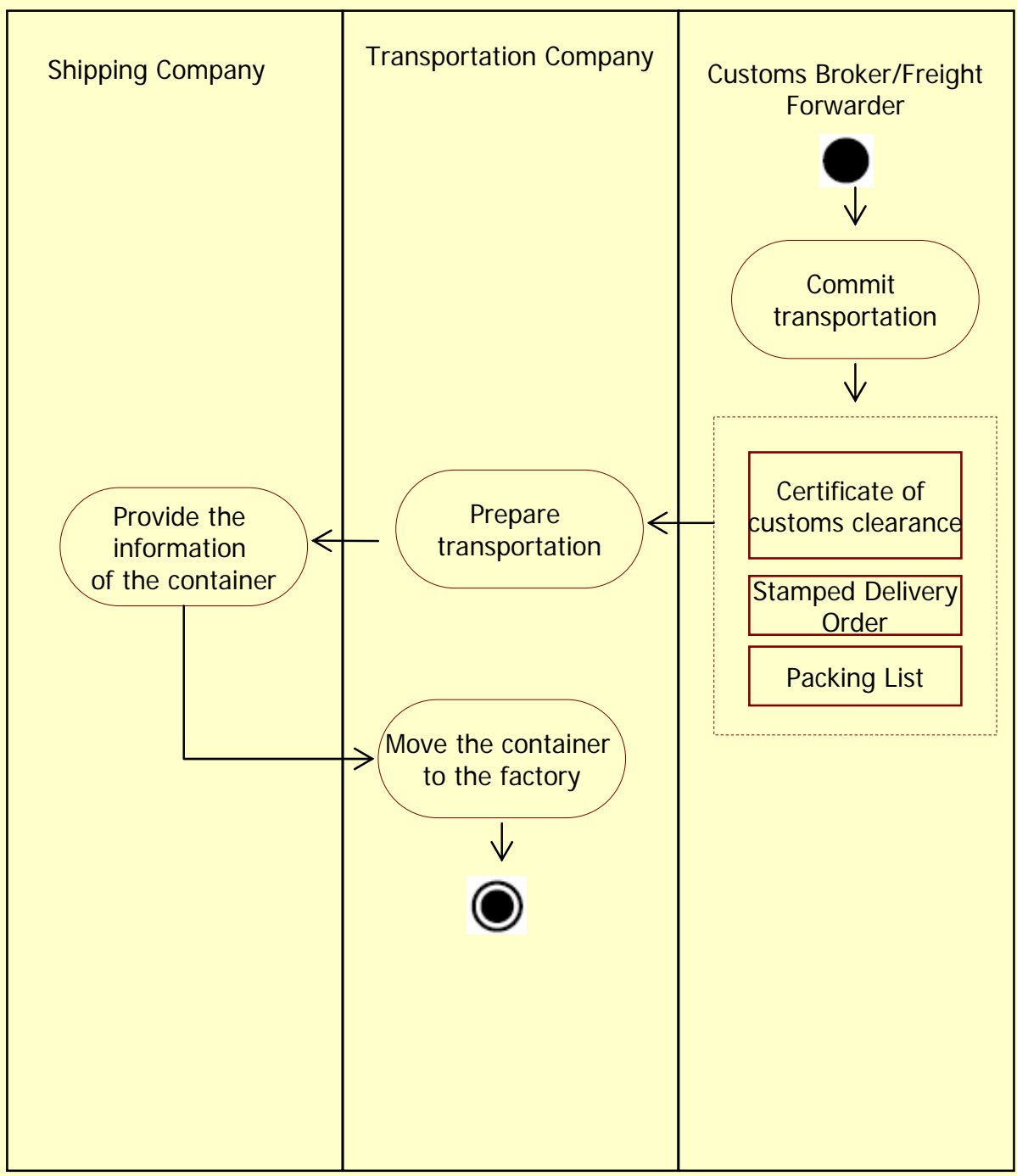

